\title{
LATIN AMERICAN FINANCIAL DEVELOPMENT IN PERSPECTIVE
}

Alicia García Herrero, Javier Santillán

Sonsoles Gallego, Lucía Cuadro and Carlos Egea

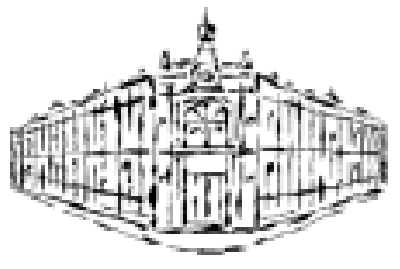

Banco de España - Servicio de Estudios

Documento de Trabajo n. ${ }^{\circ} 0216$ 


\title{
LATIN AMERICAN FINANCIAL DEVELOPMENT IN PERSPECTIVE
}

\author{
Alicia García Herrero, Javier Santillán \\ Sonsoles Gallego, Lucía Cuadro and Carlos Egea ${ }^{1}$
}

July, 2002

\begin{abstract}
This paper assesses financial sector development in Latin America, both in the banking system and in the capital markets. After a brief review of the explanatory factors and the definitions of financial development found in the literature, Latin American countries are classified in groups of similar characteristics by using cluster analysis - first worldwide and second within the region - in terms of financial depth and per capita income. In the worldwide exercise, virtually all Latin American countries appear in the same cluster, which argues in favor of a regional dimension in financial development. A comparison of the Asian and Eastern European emerging regions shows that Latin America lags behind Asia in terms of financial development and compares slightly unfavorably with Eastern Europe. In the regional cluster exercise, four relatively homogeneous groups of Latin American countries are found. Stylized facts of the four groups' banking sectors and capital markets show - in line with the results of the more recent economic literature - that those countries which have deeper financial systems are also those with a more efficient financial system. Although no conclusions on causality can be drawn from this review, it argues in favor of a virtuous circle, in terms of financial depth and efficiency, for countries with the most appropriate structure of the financial system.
\end{abstract}

JEL Classification Numbers: G1O, G20, C82

Key words: Financial development, Latin American financial systems, cluster analysis

\footnotetext{
${ }^{1}$ The paper was prepared for the Madrid Seminar of the Eurosystem and Latin American Central Banks, which took place in Madrid on 23 May, 2002. All authors are from Banco de España. The authors gratefully acknowledge comments by E. Alberola, A. Baqueiro, A. Díaz de León, S. Fernández de Lis, A. GalindoAndrade, C. González Iturriaga, I. Hernando, M. C. Manzano, H. Temprano, M. Urrutia and J. Viñals on an earlier version of the paper. All remaining errors are our own. The usual disclaimer applies. Corresponding address: alicia.garcia-herrero@bde.es.
} 


\section{TABLE OF CONTENTS}

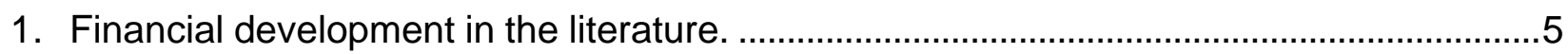

1.1. Determinants of financial development. ..................................................................

1.1.1. Financial structure: bank versus capital markets financing ...............................

1.1.2. Financial liberalization ...............................................................................

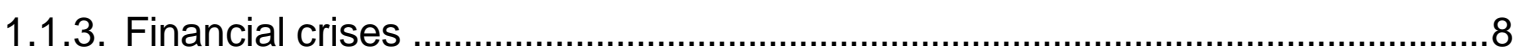

1.1.4. International (or regional) financial integration................................................

1.1.5. The structure of the banking system: ownership and concentration.................9

1.1.6. The central bank, regulation and supervision and deposit insurance..............10

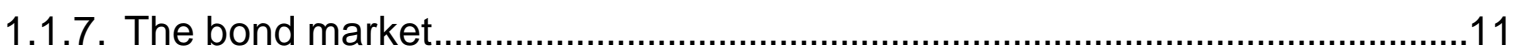

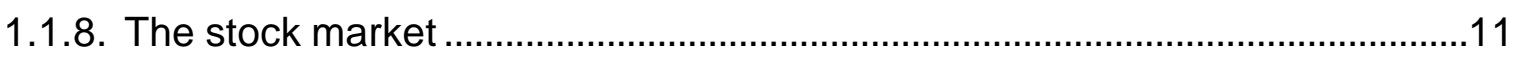

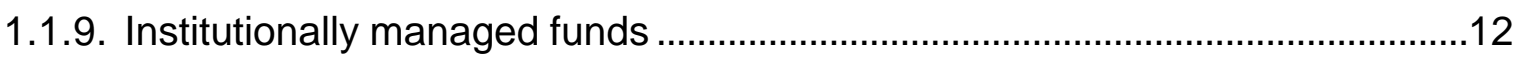

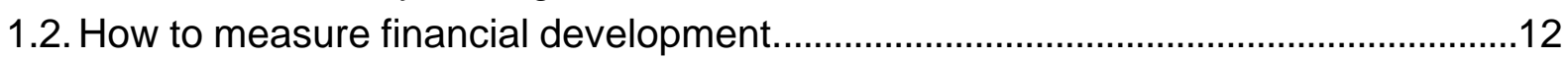

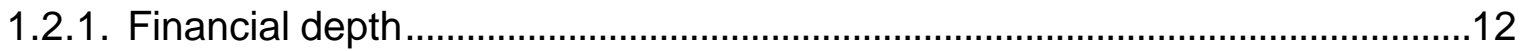

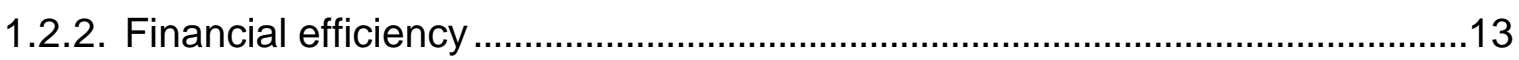

1.2.3. Relation between financial depth and financial efficiency.................................14

2. Regional trends in financial development in the world..............................................14

3. Highlights of financial development in emerging regions: Where does Latin

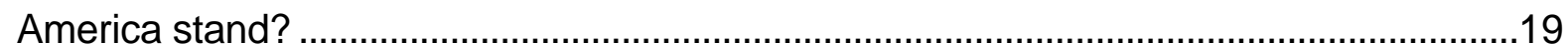

4. Differences in financial development in Latin America: a country classification.............24

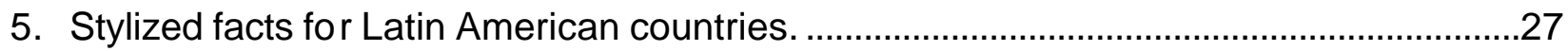

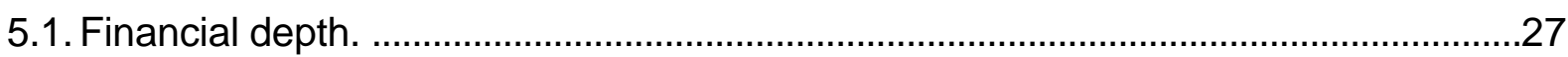

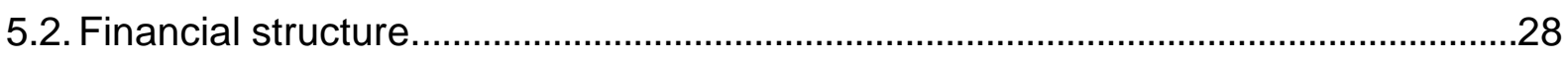

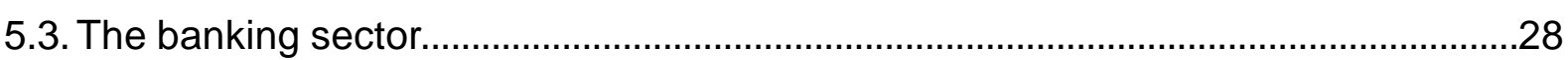

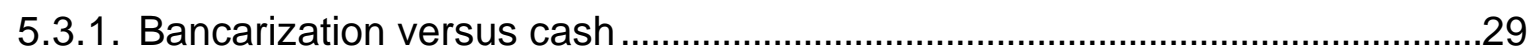

5.3.2. Size of central bank assets compared to the banking system ..........................30

5.3.3. Bank efficiency .............................................................................................

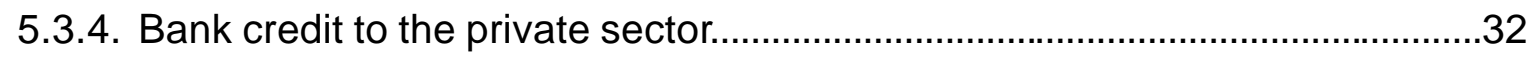

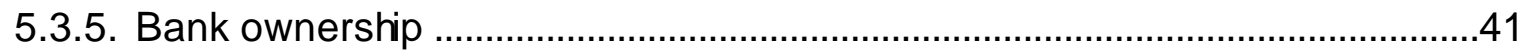

5.3.6. Bank concentration...................................................................................... 42

5.3.7. Institutional factors: the central bank and bank supervision and regulation...42

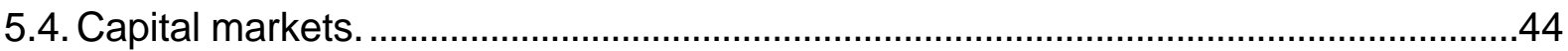

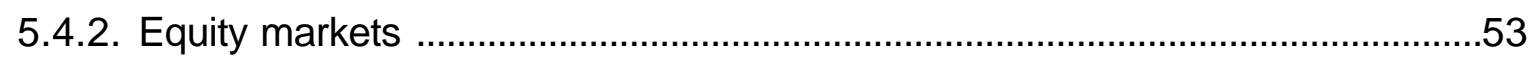

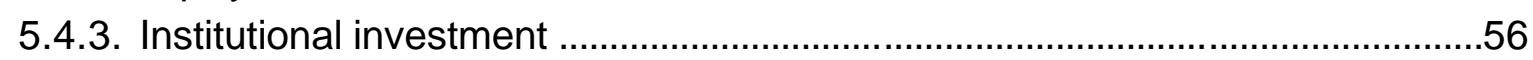

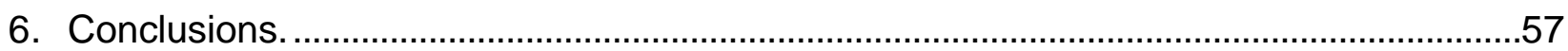

Appendix I: A brief note on cluster analysis. ......................................................................60

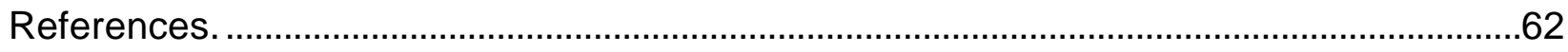




\section{GRAPHS}

1. Financial depth in the world: cluster classification. .......................................................16

2. Scattered plot of financial depth and per capita GDP worldwide....................................17

3. Inflation and financial depth worldwide .......................................................................17

4. Financial depth and macroeconomic volatility worldwide ..............................................18

5. Savings and financial depth worldwide ......................................................................18

6. Financial depth in emerging regions. Total financial assets ........................................19

7. Banking sector soundness in emerging regions. Profitability and solvency ratios ..........20

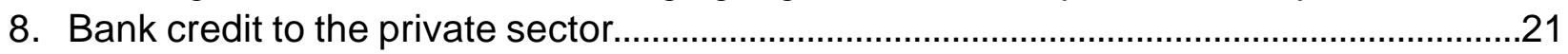

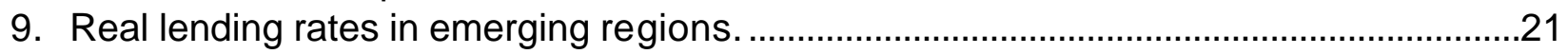

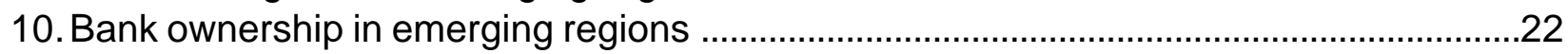

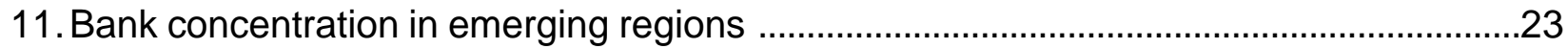

12. Stock market capitalization in emerging regions ..........................................................2

13. Financial depth in Latin America: cluster classification...................................................25

14. Scattered plot of financial depth and GDP per capita in Latin America...........................27

15. Financial depth in Latin America. Total financial assets ..............................................27

16. Financial structure in Latin America. Ratio of bank liabilities to stock market capitalization and bonds outstanding ......................................................................28

17. Bancarization in Latin America. Bank deposits ...........................................................29

18. Ratio of central banks' assets to commercial banks' assets. .........................................30

19. Profitability and efficiency: the net interest margin in selected Latin American

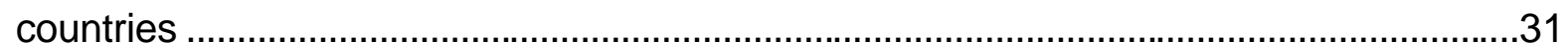

20. Bank efficiency and bank depth in Latin America ..........................................................31

21. Bank credit to the private sector in Latin America.........................................................32

22. Short and long term credit to total credit in selected Latin American countries ..............33

23. Non-performing loans and private credit in selected Latin American countries. ..............33

24. Financial liberalization, banking crises and financial depth in selected Latin American countries........................................................................... 35 - 36

25. Risk-weighted capital ratio in selected Latin American banking systems .......................37

26. Loan loss provisioning to total loans in selected Latin American banking systems ........37

27. Mexico: Credit to the private sector ................................................................................38

28. Bank credit to the public sector in Latin America ...........................................................39

29. Real lending rates in Latin America..............................................................................

30. External loans to non-financial enterprises in selected Latin American countries ..........40

31. Bank ownership in Latin America................................................................................. 41

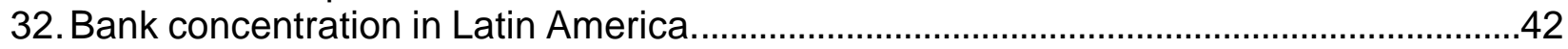

33. Institutional factors in selected Latin American countries ...............................................43

34. The quality of bank regulation and supervision in Latin America ....................................4

35. Latin American Domestic Bonds: Amounts outstanding ................................................46

36. Outstanding government bonds in selected Latin American countries: domestic and external................................................................................................ 46

37. Domestic versus external interest rates in selected Latin American countries............. 48 - 49

38. Turnover in the selected Latin American government bond markets. ............................50

39. Outstanding government bonds' maturity in selected Latin American countries.............51 
40. Interest rate structure of outstanding government bonds ............................................52

41. Domestic government debt by currency of denomination...............................................52

42. Holders of domestic government bonds outstanding ...................................................53

43. Stock market capitalization by country in selected Latin American countries ................54

44. Stock market capitalization and turnover in Latin America.............................................55

45. Pension fund assets under management .....................................................................56 


\section{Financial development in the literature}

Recent research broadly agrees that financial development contributes to economic growth ${ }^{2}$. The so-called "finance-led" economic literature on growth argues that financial development improves total factor productivity and, ultimately, economic growth through the functions inherent to the financial system, namely mobilizing savings, allocating capital, monitoring borrowers and transforming risk. In addition, even in a world of perfect capital mobility, domestic saving and investment rates are highly correlated, which makes domestic saving ratios and domestic financial development very relevant for economic growth.

Empirical financial literature is plentiful of success cases of financial development ${ }^{3}$, but also of less positive experiences. The main general conclusion that one can draw from this literature is that there is no single success model although useful lessons can be drawn from other countries' positive experiences and mistakes.

This paper assesses financial sector development in Latin America, both in the domestic banking system and in the domestic capital markets. As a first step, the literature on the determinants and definitions of financial development is reviewed. Second, Latin American countries are classified in groups of similar characteristics by using cluster analysis - first worldwide and second within the region - in terms of financial depth and per capita income. Third, stylized facts are used to compare Latin American financial development, as well as its main explanatory factors, with other emerging regions, namely Asia and Eastern Europe. Fourth, cluster analysis is used again to classify Latin American countries among themselves. Based on this group classification, the situation of the banking system and the capital markets in the different Latin American groups is reviewed taking stock of the consensus views gathered in the literature on the factors which foster or hinder financial development. The last section draws conclusions for the region.

\footnotetext{
${ }^{2}$ The debate on the role of financial systems on growth is well-rooted in the history of economic thought. Already Bagehot (1873) and Schumpeter (1911) attributed a key role for economic development to a country's banking system. The recent interest in the role of the financial system on growth is related to the new growth theory. While innovation and knowledge creation are the main forces behind capital accumulation and growth in this literature, financial intermediaries also play a role to the extent that innovation and knowledge are financed with external funds (Greenwood and Jovanovic, 1990; Levine, 1991; King and Levine, 1993a and 1993b; and Chen, Yeong-Yuh and Ping Wang, 1996).

${ }^{3}$ Rousseau and Sylla (2001) carry out a historical review of the Dutch Republic, England, the U.S., France, Germany and Japan and show how, in each case, the emergence of a financial system jump-started economic growth. Allen and Gale (2000) provide a comprehensive analysis for a similar group of countries. Caprio, Hanson and Honohan (2001) review the benefits and pitfalls of financial liberalization in emerging markets.
} 


\subsection{Determinants of financial development}

There are several factors that affect financial development. The first to be identified in the economic literature were macroeconomic factors, such as inflation and how wealthy countries are in terms of GDP per capita and the saving rate. Boyd, Levine and Smith (2000) find empirical evidence that at low-to-moderate rates of inflation, increases in inflation hamper financial development, reducing the amount of financing to the private sector. Khan, Abdelhak and Smith (2001) obtain the same result with the addition of a floor for inflation, below which financial development is hampered as well. More specifically, they show that inflation below $3 \%$ and above $6 \%$ is detrimental for financial deepening. As for wealth, Jaffee and Levonian (2000) obtain empirical evidence that both GDP per capita and savings are significant to explain financial development.

More recently, institutional factors have been found key for financial development, and in particular the legal and regulatory system. Levine, Loayza and Beck (1999) state that countries with creditor-friendly legal systems have better functioning financial intermediaries. The IADB (2001) reports the same result for Latin American countries. In the same vein, Black (2000) shows that investor protection is critical for the development of the securities market. Lombardo and Pagano (1999) obtain the same result for the stock market.

This paper will not concentrate on macroeconomic and general institutional factors since there have been widely documented in the literature but will take them as given. In turn, it will focus on those factors that relate to the financial system itself.

\subsubsection{Financial structure: bank versus capital markets financing}

The long-standing debate as to whether bank financing or capital market financing is better for economic growth seems to have reached consensus with recent research. La Porta, Lopez-de-Silanes, Shleifer and Vishny (1997), and Barth, Caprio and Levine (2001) ${ }^{4}$ show evidence that the choice between a bank-based and a capital-market based structure is not key for financial development but rather the institutional factors behind the financial structure, and in particular the legal environment, as well as the degree of efficiency of the structure chosen. Allen and Gale (2000) reach similar conclusions after describing the trade-offs of both models and argue that the appropriate choice must be made on an ad-hoc basis depending on issues such as the importance attributed to the redistribution of risk and funding

\footnotetext{
${ }^{4}$ Beck and Levine (2000) obtain the same result, the latter with firm-level data, as regards external financing. Indeed, they find no evidence that firms' access to external financing is predicted by a country's score on any of several indices measuring the development of capital markets relative to that of the banking system.
} 
of financial institutions. ${ }^{5}$ All this, however, does not mean that the financial structure is irrelevant. In fact, there is growing evidence that most success cases of financial development have a relatively balanced mixture of capital markets and bank financing since they tend to act as complements rather than substitutes (Davis, 2001). ${ }^{6}$

\subsubsection{Financial liberalization}

In order to analyze the impact of financial liberalization on financial development, two differences should be made: first between domestic and external financial liberalization (especially as regards the capital account) - although it is common that both liberalization processes are closely linked (Williamson and Mahar, 1998) -, and second between the transition and the steady state phase. Regarding the first point, evidence of the positive link between liberalization and financial development is stronger for the domestic part of the process than for the external one ${ }^{7}$. The impact of capital account liberalization appears to be much more dependent on certain conditions. On the one hand, it gives the opportunity of receiving more funds to develop domestic financial markets, especially when control on foreign ownership of banks is relaxed (IMF, 2000). On the other hand, it carries severe risks of financial instability if the appropriate institutional framework is not in place when liberalizing. All in all, the empirical evidence finds a long run positive correlation between financial development and capital account openness (Bailliu, 2000 and Galindo Micco and Ordoñez $\left(2002^{8}\right)$. The fact that the correlation is found for the long run leads to the second point: the transition from a repressed to a liberalized financial system is much more problematic than the steady state, because of the potentially ensuing crises. The reasons given in the literature for the risks of the transition are many-fold. First, increased competition stemming from liberalization erodes the margins of financial firms. Second, uncertainty increases as financial firms are unfamiliar with the new situation. Third, liberalization raises the risk exposure of financial firms through unconstrained lending activities, particularly if internal risk control systems are weak as is often the case in emerging countries. Forth, supervisors tend to react too slowly to the potential risks that financial liberalization brings into the financial system.

\footnotetext{
${ }^{5}$ Another interesting analysis is that of Rybczynski (1997), who distinguishes three stages of evolution of financial systems, namely bank-oriented, market oriented and securitised. According to his analysis, the latter is the outcome of a natural evolution towards which all financial systems tend to converge.

${ }^{6} \mathrm{He}$ also finds that a balanced financial structure, not only in terms of size but also in terms of access of companies to both bank lending and the securities markets, is beneficial for financial stability.

${ }^{7}$ Note that even the domestic liberalization process is not without risks. Demirguc-Kunt and Detragiache (1998) find that banking crises are more likely to occur in liberalized financial systems, although the impact of financial liberalization in banking sector fragility is weaker where the institutional framework is strong as illustrated by Galindo, Micco and Ordoñez (2002).

${ }^{8}$ They find a positive relation between financial liberalization and the allocation of investment, which can be considered to reflect the efficiency in the intermediation of funds for useful projects.
} 


\subsubsection{Financial crises}

Financial crises are obviously detrimental for financial development in the short run since all who depend on financial services suffer. However, as mentioned previously, this may be much less so if the structure of the financial system is balanced between the banking system and the capital market and the crisis does not spread to all sources of financing. In the steady state, the impact of banking crises on financial development may vary from country to country ${ }^{9}$. If crises are tackled properly and economic activity recovers, a renewed - and sounder - financial system may constitute a better basis for the supply of the liquidity that the country needs to grow. On the contrary, if banks continued to be saddled with nonperforming loans notwithstanding, the country may not manage to develop financially even in the medium term. Cuadro, Gallego and García-Herrero (2002) find empirical evidence of a positive impact of banking crises on financial deepening for a large group of countries.

\subsubsection{International (or regional) financial integration}

There is broad consensus in the literature that opening up the financial system to the rest of the world fosters financial development, particularly for small countries. How much a country may benefit from international (or regional) financial integration in terms of financial development will very much depend on the nature of such integration, especially how stable and secure it is. Three dimensions of this process can be considered:

(i) Foreign participation in the domestic banking system is generally regarded positively for financial development: Kroszner (1998) argues that foreign entry brings fresh capital into the banking system which can be intermediated thereby increasing the size of the domestic financial system. Kono and Schuknecht (1999) show that foreign ownership limits the volatility of capital movements and financial markets in general. Finally, Claessens, Demirguc-Kunt and Huizinga (2000) and Crystal, Dages and Goldberg (2001) find that foreign ownership brings better management and expertise, fosters competition and increases solvency in terms of higher loan-loss provisioning (albeit compensated by a higher interest rate margin). However, the potentially destabilizing effects of foreign banks are sometimes also brought into the picture. Caballero (2002) states that countries with deeper foreign banking may be more vulnerable to productivity shocks since foreign banks can take deposits out of the country and intermediate them in other countries which do not suffer from those shocks.

(ii) External financing, which is facilitated through external financial liberalization, should generally foster domestic financial development, at least in the long run. In such case,

\footnotetext{
${ }^{9}$ Caprio and Klingebiel (1999) review the causes and effects of eighty six banking crises' causes and effects and classify subsequent restructurings according to their degree of success.
} 
external financing would act as a complement of domestic financing, and not as a substitute. Jaffee and Levonian (2000) support this view with the finding that the opening up to external financing, measured as the ratio of non-resident claims to total claims on banks, increases financial depth for a large group of countries. In addition, Bekaert, Harvey and Lumsdaine (2000) find that market capitalization jumped after the opening of the stock market to foreign investors and there was also a sharp increase in the liquidity, measured by the ratio of average value traded to GDP. Also, opening up securities markets to foreign investors has improved the efficiency of local bond markets. One good example is the opening of European government securities markets to foreign investors during the late 1980s and early 1990s.

(iii) Regional integration of banks, capital markets and infrastructure should be beneficial for financial development, especially in the case of small countries, because of the potential efficiency gains from economies of scale and scope ${ }^{10}$. Based on the European experience, the integration process can be achieved quicker in bond markets than in banking and, within the latter, in investment banking than in retail banking, where the differences in consumer behavior limit the benefits of the economies of scale ${ }^{11}$. Sharing financial infrastructure with other countries in a region, or simply importing key infrastructure from a more developed country, allow financial modernization with a lower cost and should facilitate the entry of foreign investment. The European experience has been very successful as regards the payments system while progress is underway in the field of securities. As regards emerging countries, including Latin America, regional integration is far, notwithstanding the potential gains that could be obtained given their small financial depth (Heaney, Hooper and Jangietis, 2000).

\subsubsection{The structure of the banking system: ownership and concentration}

There is a general consensus that public ownership - except for some isolated cases of success - tends to be associated with less financial sector development, lower economic growth, and lower productivity, and that these effects are larger at lower levels of income and with weaker property right protection (La Porta, López de Silanes and Zamarripa, 2000). In addition, Barth, Caprio and Levine (2001) find that widespread state ownership is generally associated with higher loan-deposit interest rate spreads, less private credit and less activity

\footnotetext{
${ }^{10}$ Berger (2000) finds empirical evidence of the large potential for efficiency gains from integration although only a small part of these gains are generally realized. Most of the gains appear to be linked to the benefits of risk diversification.

${ }^{11}$ When discussing integration, however, one must have in mind the global trends, mainly due to technological developments, which are already shaping structural changes in financial markets worldwide. Issues such as the ongoing integration of trading, clearing and settlement systems are not specifically discussed here but are very relevant and will be more so in the near future worldwide and also for Latin American financial systems.
} 
on the stock market. The government failure as bank owner may be attributed to the excessive importance of political considerations in its management of banks, particularly if one considers that the few cases of more successful state ownership appear in strong institutional environments ${ }^{12}$. The process towards bank privatization either to sound domestic players or to foreign ones is, therefore, highly welcome in the literature ${ }^{13}$.

As for the concentration of banking activity in a few banks, too much appears as bad as too little. While there are economies of scale and scope from concentration ${ }^{14}$, too much concentration may lead to oligopolistic behavior and inefficiencies. This will highly depend on the degree of competition in the country's economy in general, as well as on the existence of other financing means, mainly capital markets.

\subsubsection{The central bank, regulation and supervision and deposit insurance}

The central bank plays an important role in financial development. First and foremost, it shapes the liquidity conditions of the banking system, which affects the profitability and eventually - the soundness of banks. This is related to the main objective of the central bank, price stability. As regards other functions, the central bank is often in charge of ensuring efficient and secure payment system services, either by directly operating them or by supervising them. The well functioning infrastructure of money markets and, sometimes the government debt markets, may also be a responsibility of the central bank. In this regard, Cuadro, Gallego and García-Herrero (2002) find evidence that central banks with narrower functions ${ }^{15}$, other things given, are associated with larger financial systems in industrial countries, but the same cannot be found for emerging countries.

As regards bank regulation and supervision, which, in Latin America, is in the hands of the central bank only in a few cases, the literature has long argued that high quality regulation and supervision foster financial development but it was difficult to find empirical evidence of it because of lack of comparable information on regulation and supervision in a large number of countries. An important exception is Demirguc-Kunt and Levine (1999), who find evidence that countries with regulations that overly restrict the rights of banks to engage in securities markets' activities, real state and insurance, are more likely to have underdeveloped financial systems.

\footnotetext{
${ }^{12}$ The potential gains of privatization have been explored at length (see World Bank, 2001b).

${ }^{13}$ See the previous section on the positive impact of foreign ownership on financial development.

${ }^{14}$ Berger (2000).

${ }^{15}$ Those included in this exercise are the payments system functions of the central bank, the lender of last resort instruments, and the objectives of the central bank.
} 
As regards deposit insurance schemes (DIS), they appear to foster financial development as long as the regulatory system is sound (Cull, Senbet and Sorge, 2000) but, if unlimited, they may increase the probability of banking crises (Demirguc-Kunt and Detragiache, 1998). In addition, Demirguc-Kunt and Levine (1999) find that countries with explicit DIS tend to have more bank-based financial systems.

\subsubsection{The bond market}

The empirical literature on bond market development is much more scarce, especially as concerns domestic bond markets. These have often been overlooked because of lack of data and their very heterogeneous nature in each country. However, a few recent studies seem to highlight the relevance of bond markets, and in particular of domestic bond markets, for financial development. This contrasts with some approaches that have highlighted the risks that bond markets may become vehicles to expand government deficits. Domestic bond markets, and especially government bonds as such - and not so much the fiscal position they finance - are now considered instrumental for the management of monetary policy because of their collateral function. In addition, a deep government bond market contributes to securitization and providing the market with a benchmark on which the private bond market can develop. In this vein, Cole and Slade (1999) review a few cases of premature liberalization of government debt markets and argue that, if not accompanied by sufficient fiscal discipline, real interest rates will increase as well as the burden of the debt service.

As regards the external bond market, the literature is generally in line with the previously mentioned view that external and domestic sources of financing should act as complements rather than substitutes. Gray and Woo (2000) conduct an evaluation of the benefits of external sovereign debt and conclude that there are potential costs in cases in which they are the only source of financing and that countries should increase the share of sovereign debt held domestically.

\subsubsection{The stock market}

Stock markets and their influence on financial development have been studied more systematically. Fuchs-Schundeln and Funke (2001) analyze empirically the effects of stock market liberalization on financial and macroeconomic development and find that liberalization has an immediate positive effect on market capitalization growth and a similar one on the average turnover ratio growth.

As for external financing through the stock market, the huge growth of cross-border equity investment either in the form of foreign direct investment (FDI) or in the form of portfolio 
investment in emerging countries explains the interest paid by the literature to stock market development. Although the burst of the bubble at the onset of the Asian - and to a lesser extent - Mexican crises has raised doubts about the inherent volatility of the stock market in emerging countries, this seems more linked to the currency crises that these countries experienced than to the stock market liberalization process (World Bank, 2001)

\subsubsection{Institutionally managed funds}

There is a consensus on the positive influence of institutionally managed funds for financial development, especially as regards long-term financing. In particular, private pension funds with their appetite for longer-term investments and their relatively large and increasing size, should act as a main driver for the domestic bond and stock market development (Vittas, 2000, and Catalán, Impávido and Musalem, 2000). ${ }^{16}$ In addition, the existence of a large domestic bond or stock market does not appear to be a pre-condition for the development of contractual savings, as Vittas (1998) shows. In the same line, Kaminsky, Lyons and Schmuckler (2000) analyze mutual funds as important contributors to financial-market integration.

\subsection{How to measure financial development}

There is no uniformly accepted definition of financial development especially when one takes into account countries' specificities. To add to the difficulty, a cross-country study such as this one needs a measure homogeneous enough to allow comparison.

There are two main aspects of financial development. One is financial depth, in terms of the size of the financial system, and the other is its efficiency. The literature has dealt with the former at length and much less so with the latter.

\subsubsection{Financial depth}

The measures proposed in the literature for financial depth have evolved over time, concentrating at a first stage on the banking system and then expanding to the capital markets. Among the narrower measures, liquid liabilities (or M2) to GDP is the best known one and most widely used (McKinnon 1973). More recently Levine, Loayza and Beck (1999) have used commercial bank to central bank assets as a proxy of the size of the funds intermediated effectively. This is due to the potential substitutability between central bank and

\footnotetext{
${ }^{16}$ The extent to which private pension funds foster domestic capital markets is related, among other factors, to regulation, since most countries tend to limit the amount that can be invested abroad.
} 
commercial bank credit, particularly for less developed countries. ${ }^{17}$ Finally, a very commonly used definition of financial depth is commercial bank credit to the private sector relative to GDP (Levine and Zervos, 1998). This, as the ratio of commercial bank to central bank assets, not only reflects financial depth but efficiency as well, due to the potential substitutability between public and private credit, being the latter more conducive to growth. There is another interesting twist to private credit: its too rapid growth might be interpreted quite differently, being one of the most reliable indicators of financial crises in the empirical literature (McKinnon and Pill, 1997, Kaminsky and Reinhart, 1999).

Wider measures of financial depth include the domestic capital markets. Rajan and Zingales (1998) take assets of the banking and other deposit-taking institutions, bond issuance, and stock market capitalization, all relative to GDP. Although broad, the latter measure still misses important sources of financing, such as enterprise financing ${ }^{18}$, external financing (through interbank loans or bonds) and the informal financial sector ${ }^{19}$.

\subsubsection{Financial efficiency}

There is no simple measure of overall efficiency of the financial system but several for each market that composes it. For the banking sector, the most widely used measures are the net interest margin, defined as the bank interest income minus interest expense, over overhead cost, and the ratio of overhead costs to total assets (Demirguc-Kunt and Levine, 1999). The inverse of the net interest margin can be considered as a measure of financial efficiency since tighter margins are frequently associated with greater competition, although there may be other reasons, such as low interest rates, particularly in developed countries, and macroeconomic volatility in emerging ones. ${ }^{20}$ Overhead costs are a more ambiguous measure since an increase in efficiency may temporarily imply large overhead costs if competitive banks undertake substantial investment to improve the quality of the financial services they provide (Demirguc-Kunt and Levine, 1999).

\footnotetext{
${ }^{17}$ The intuition behind this measure is that central banks are less likely to identify profitable investments, monitor managers, facilitate risk management and/or mobilize savings.

${ }^{18}$ Demirguc-Kunt and Maksimovic (2001) find that firms tend to act more as providers of credit to their customers when the banking system is large and efficient and has a small proportion of public ownership of the banking system.

${ }^{19}$ Informal finance is very important in many regions and, for certain groups, in almost all regions of the developing world (Besley, 1995).

${ }^{20}$ This is a particularly important reason in Latin America, as Segalla Afanasieff and Villa Lhacer, (2000) have found for Brazil, and Arreaza, Fernández and Mirabal (2001) for Venezuela.
} 
Capital market efficiency is usually defined, following Fama and Sharpe (1970), in terms of how much information is reflected in the prices of financial instruments. Weak efficiency is achieved when prices reflect all past information, semi-strong efficiency when prices include all currently available information, and strong efficiency when prices also reflect future expectations ${ }^{21}$. Ultimately, capital market efficiency depends on the deepness, breadth and resilience of markets, which is very much related to their liquidity. The most immediate measure of liquidity is the turnover, which gives the value of stock transactions relative to the size of the market (Demirguc-Kunt and Levine, 1996). In addition, the total value traded relative to GDP is frequently used as a measure of market liquidity (Levine and Zervos, 1998), together with the bid and ask spreads.

\subsubsection{Relation between financial depth and financial efficiency}

In general terms, financial depth appears to be closely related with efficiency (Bossone and Lee, $2002^{22}$ ). This, however, does not mean that "big is always better" for the financial system. There are circumstances, particularly if a banking system is in distress, when a part of the assets, no matter how large, may be unproductive or non-performing credit and, thus, do not contribute to growth ${ }^{23}$. The same banking system after a crisis tends to shrink, either because of deposit runs, the clean up of non-performing loans or bank closures, but is generally able to intermediate funds more efficiently, especially if the crisis is tackled correctly. Diaz-Alejandro (1985) argues that such "oversizing" of the banking system occurred in the Latin American countries which liberalized their banking systems in the 1970s (basically the Southern Cone), because of insufficient regulation and bailout expectations by banks. Banks became larger without a corresponding increase in efficiency, which made the system very fragile and led to banking crises.

\section{Regional trends in financial development in the world}

One of the first challenges facing any study attempting to identify regional trends is how to deal with the fact that countries might not be homogeneous regardless of their geographical proximity. This makes drawing lessons on a regional basis a generalization not without risks. Bearing these caveats in mind, and as a starting point to this study, a simple exercise is conducted to assess to what extent there are regional characteristics in the financial

\footnotetext{
${ }^{21}$ Another important concept is operational efficiency, which can be described as the combination of elements which ensure secure, cheap and fast transactions. This definition is, hence, focused on institutional aspects of the functioning of markets, including regulatory issues and the clearing and settlement.

${ }^{22}$ The authors find this result for a large panel with banking data for a number of countries.

${ }^{23}$ Unproductive credit was common in several Asian countries before the 1997 crisis (see Demetriades and Fattouh, 2000), while non-performing loans were one of the main constraints for growth in transition countries.
} 
development of Latin American countries, comparing them with a large sample of industrialized and emerging countries.

We conducted a simple cluster analysis with two variables - financial depth and per capita income - and applied it to a large data set of Asian, Eastern and Western European and American countries. ${ }^{24}$ Cluster analysis identifies groups of countries that are broadly homogeneous in terms of the variables chosen in this case, financial development and per capita income (the methodology used is described in Appendix I). Given the lack of a definition of efficiency for the financial system as a whole, the cluster classification is based on financial depth only. A wide measure of financial depth has been chosen (including the capital markets), in line with the most recent literature ${ }^{25}$, so as not to underestimate the development of countries that are relatively more capital-market oriented. Financial depth is, thus, defined as the sum of liquid liabilities ${ }^{26}$, stock market capitalization and bonds outstanding relative to GDP. Per capita income is defined in PPP terms.

The results (graph 1) yield five major clusters within the world sample. The first and most developed one is composed of Japan and the US. The second comprises most European Union countries but also the Asian financial centers, and Canada. The third includes other Western European countries, some Asian ones, the Czech Republic and Chile, which stands as the only Latin American country in a relatively developed cluster. The fourth cluster comprises the remaining European countries, and the fifth all Latin American countries but Chile, and the remaining Asian and Central-Eastern Eastern European countries. Interestingly enough, this last cluster - even if composed of the largest number of countries - is the most homogeneous one in terms of the variability of the two variables it is based on (financial depth and GDP per capita), followed by Cluster 1. Finally, the correlation between per capita income and financial depth is $66 \%$, which means that there must be other important factors - besides

\footnotetext{
${ }^{24}$ Due to the data availability problems for such a large number of countries, the year chosen was 1996 . The countries included in the analysis can be found in graph 1.

${ }^{25}$ Rajan and Zingales (1998) and Demirguc-Kunt and Levine (1999).

${ }^{26}$ We have chosen the liability side, rather than the asset side, of the banking system and other financial institutions (as in Rajan and Zingales, 1998), to reflect the financing nature of all the components of the definition of financial depth.
} 
GDP per capita - explaining the relatively larger financial depth of a country compared to another. 
G1 Financial depth in the world: cluster classification

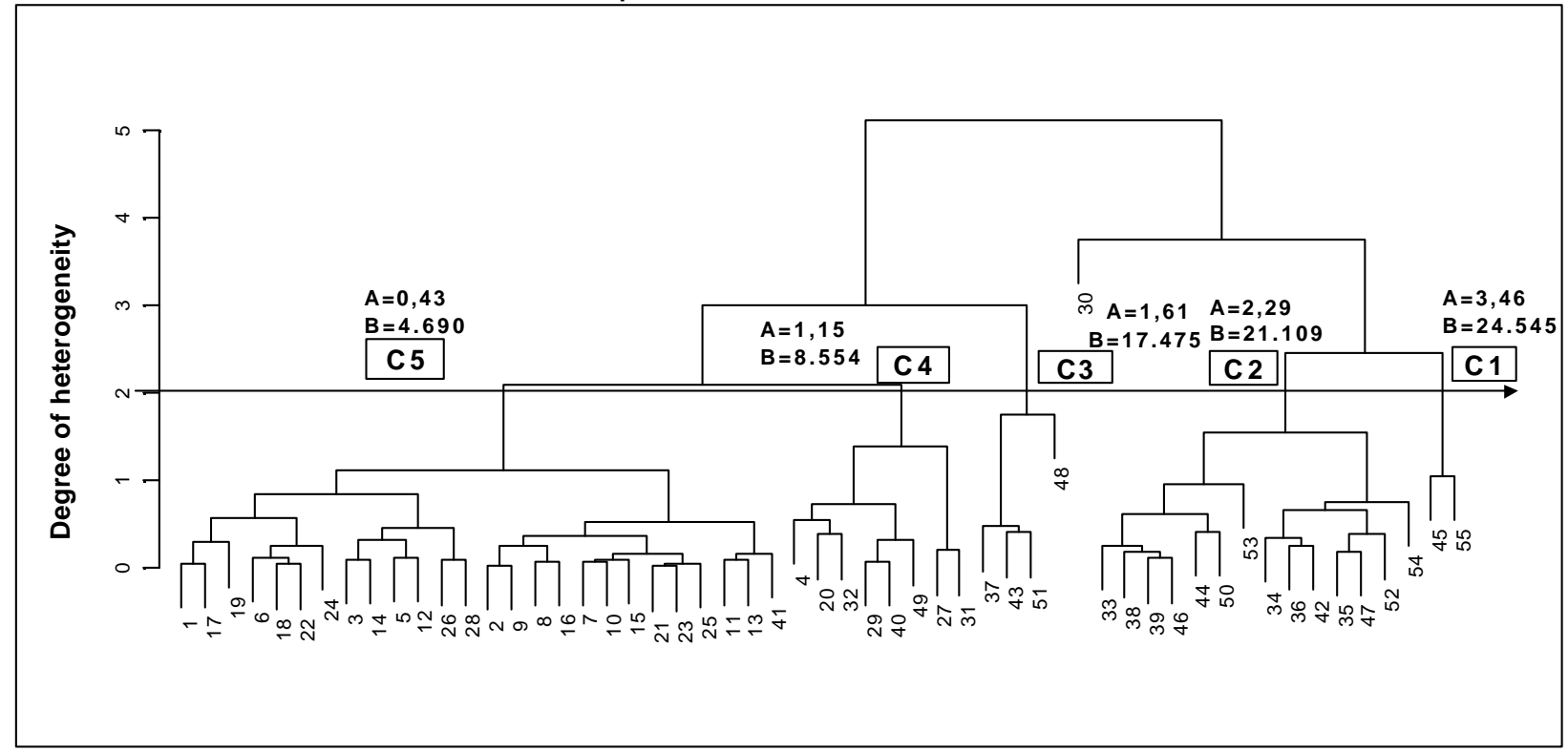

Data for 1996

(A) Financial depth

(B) GDP per capita

Source: Beck et al. (1999), IFS, World Bank, and own calculations.

Note: Financial depth is composed of bank liquid liabilities (M2), plus stock market capitalization, plus public and private bonds outstanding, all as percentage of GDP. GDP per capita is defined in PPP terms.

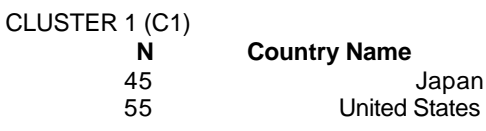

CLUSTER $2(\mathrm{C} 2)$

$\begin{array}{rr}\text { N } & \text { Country Name } \\ 33 & \text { Austria } \\ 34 & \text { Belgium } \\ 35 & \text { Canada } \\ 36 & \text { Denmark } \\ 38 & \text { France } \\ 39 & \text { Germany } \\ 42 & \text { Hong Kong, China } \\ 44 & \text { Italy } \\ 46 & \text { Luxembourg } \\ 47 & \text { Netherlands } \\ 50 & \text { Singapore } \\ 52 & \text { Sweden } \\ 53 & \text { Switzerland } \\ 54 & \text { United Kingdom }\end{array}$

$\begin{array}{cr}\text { CLUSTER } 3(\mathrm{C} 3) & \\ \mathbf{N} & \text { Country Name } \\ 37 & \text { Finland } \\ 43 & \text { Ireland } \\ 48 & \text { Norway } \\ 51 & \text { Spain }\end{array}$

CLUSTER 4 (C4)

$\begin{array}{rr}\text { N } & \text { Country Name } \\ 4 & \text { Chile } \\ 27 & \text { China } \\ 20 & \text { Czech Republic } \\ 40 & \text { Greece } \\ 29 & \text { Korea. } \\ 31 & \text { Philippines }\end{array}$

49 Portugal

CLUSTER 5 (C5)

Country Name

Argentina

Bolivia

Brazil

Colombia

Costa Rica

Dominican Republic

Ecuador

El Salvador

Estonia

Guatemala

Haiti

Honduras

Hungary

Indonesia

Lithuania

Mexico

Nicaragua

Panama

Paraguay

Peru

Poland

Romania

Slovak Republic

Trinidad and Tobago

Uruguay

Venezuela

OUT OF CLUSTER

N Country Name

Malaysia 
Two general conclusions can be drawn from these results. First, financial systems in emerging markets, and especially in Latin America, are smaller than one would expect looking only at income per capita (graph 2). According to the finance-led school of economic development, this should constitute a constraint for growth in the region. Second, the homogeneity of Latin American countries, being all but one in the same cluster, argues in favor of a regional dimension as regards financial development.

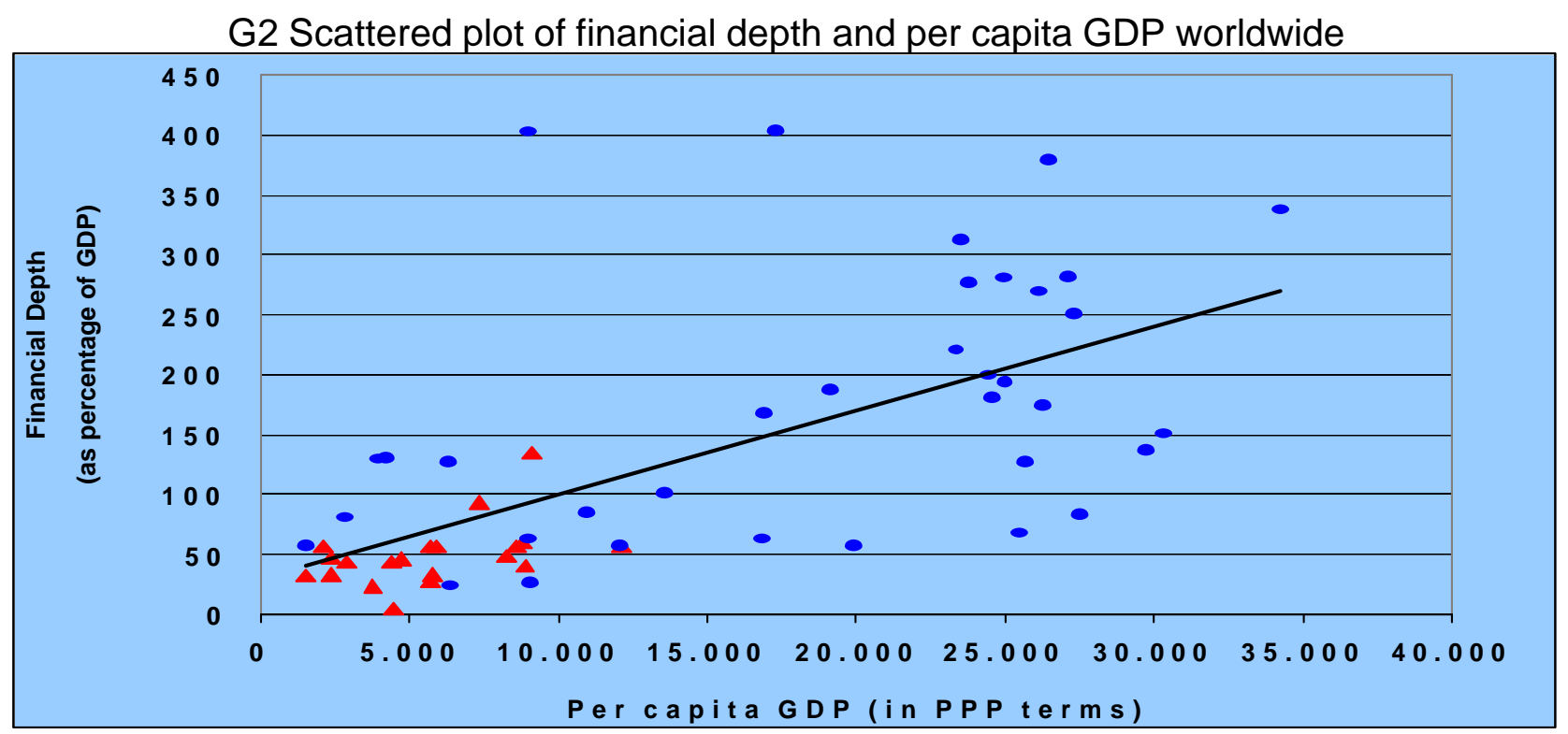

Data for 1997

Source: Beck et al. (1999).

Note: The triangle indicates Latin American countries.

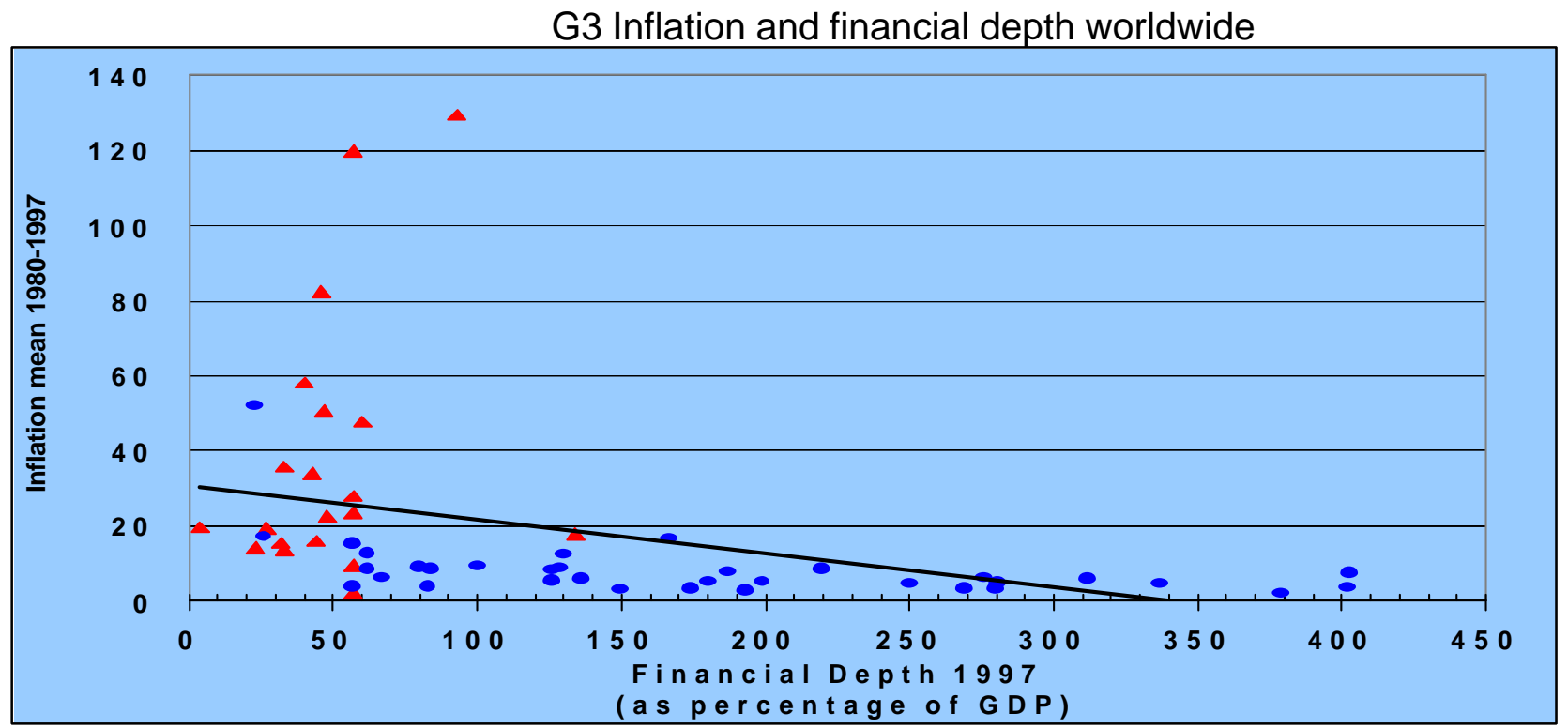

Source: IFS (2001), Beck et al. (1999) and own calculations.

Note: The triangle indicates Latin American countries. 
This regional dimension is also found when looking at the main macroeconomic factors that help explaining why some countries are more financially developed than others. Latin American countries are well above the world average of inflation in the last decade (graph 3, above) and their economies have also been more volatile ${ }^{27}$. In addition, domestic saving ratios, have generally been lower than those prevailing in the rest of the world (graphs 4 and $5)^{28}$.

G4 Financial depth and macroeconomic volatility worldwide

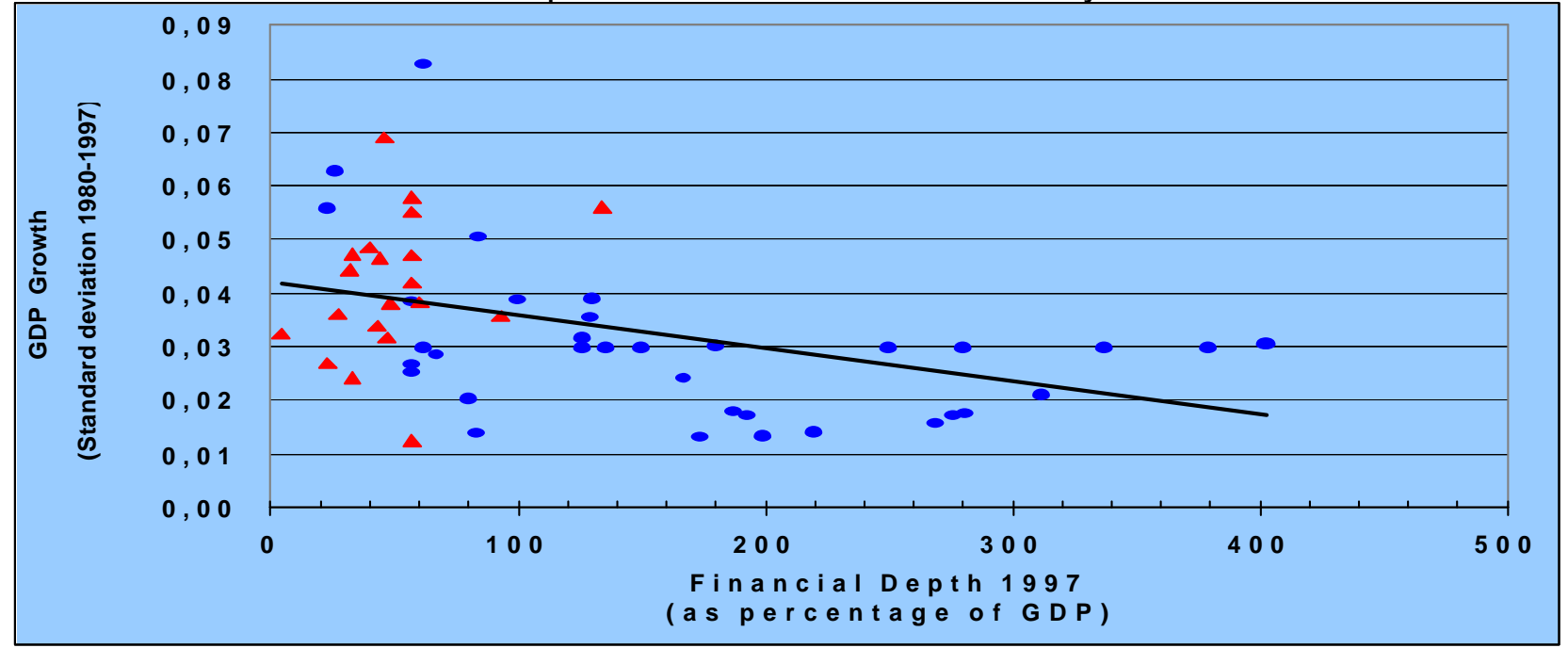

Source: IFS (2001).

Note: The triangle indicates Latin American countries.

G5 Savings and financial depth worldwide

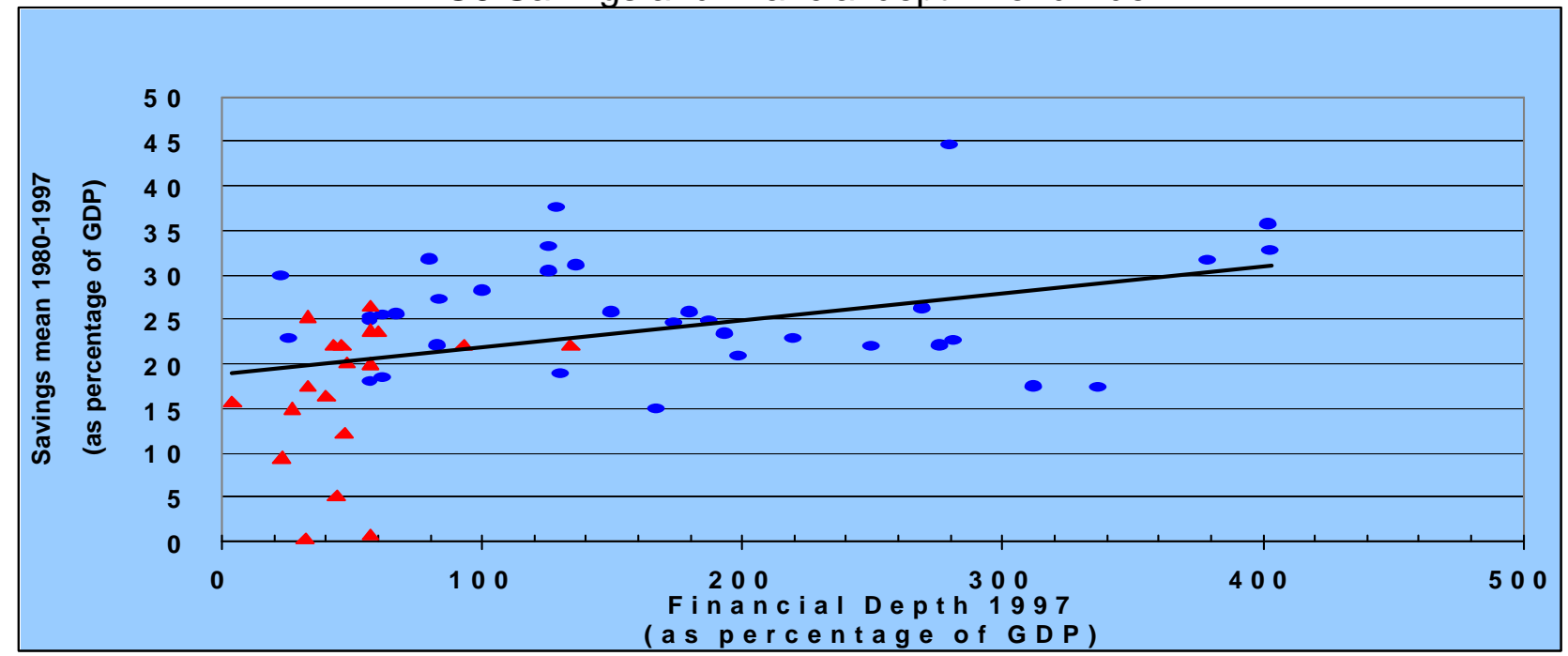

Source: IFS (2001), Beck et al. (1999) and own calculations.

Note: The triangle indicates Latin American countries.

${ }^{27}$ Caballero (2001) describes the relation that exists between macroeconomic volatility and the financial system.

${ }^{28}$ Rojas-Suárez and Weisbrod (1997). 
In sum, on the basis of the results of the worldwide cluster and the broad scope of this paper, we turn to draw some broad conclusions on a regional basis. Such conclusions should, however, be taken with caution when trying to apply them to specific countries.

\section{Highlights of financial development in emerging regions: Where does Latin America stand?}

On the basis of the common regional characteristics found above, we now depict the main trends, observed over time, of financial systems in the three emerging regions: Asia, Eastern Europe and Latin America

As regards financial depth, Latin America is much smaller than Asia, even after the Asian crisis, and comparable to Eastern Europe (graph 6). Financial sectors in Asia grew much faster than in Latin America and Eastern Europe during the 1980s and the first half of the 1990s, due to higher growth expectations and the asset price boom, which accompanied financial liberalization in Asian countries ${ }^{29}$. By 1996, just before the financial crisis erupted, the financial sector of emerging Asia was on average three times larger than that of Latin America or Eastern Europe. This difference has fallen slightly since then but it is still substantial.

G6 Financial depth in emerging regions. Total financial assets (as percentage of GDP)

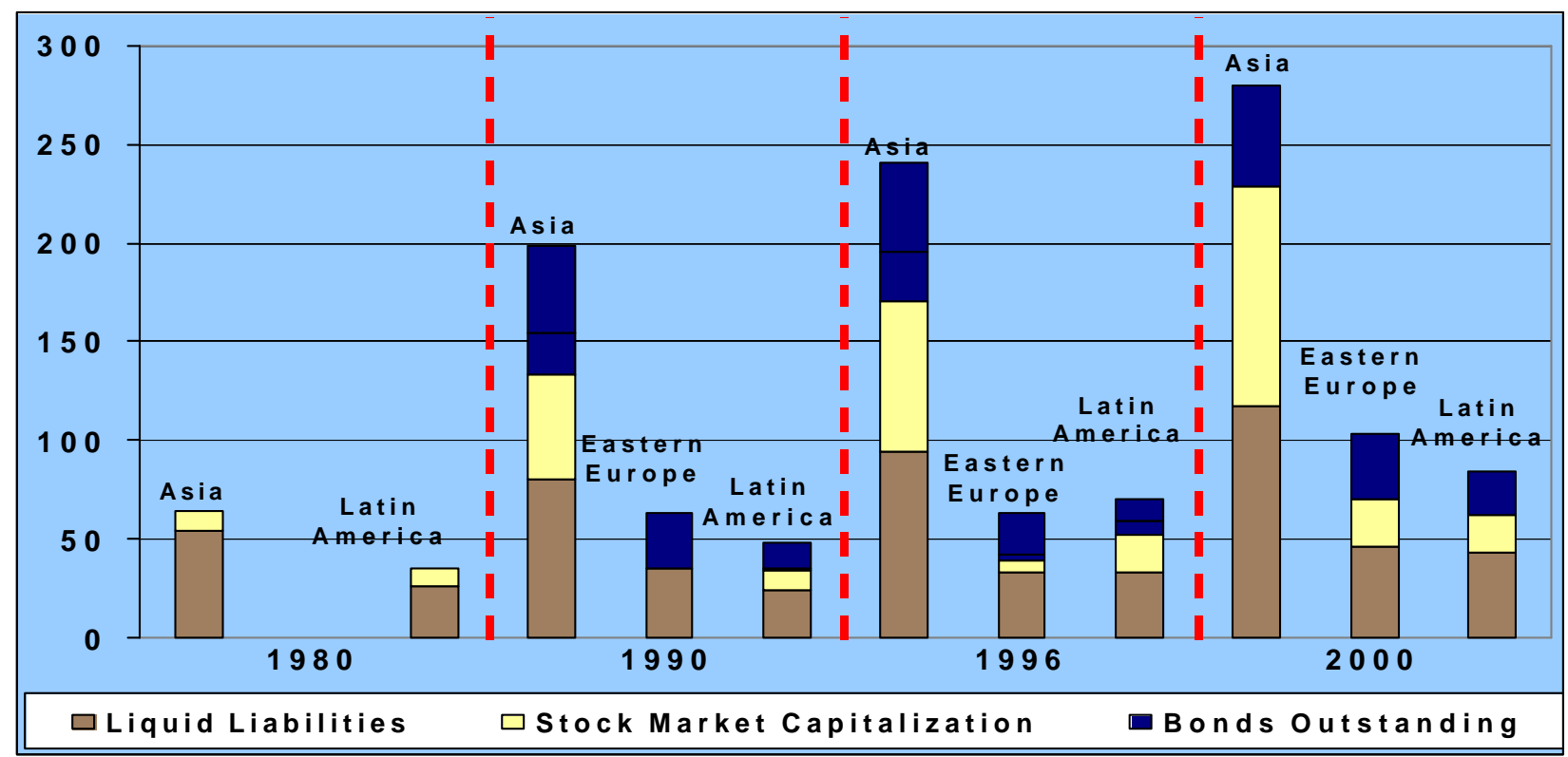

Source: Beck et al. (1999). For year 2000: IFS (2001), BIS (2001) and World Bank (2001c).

\footnotetext{
${ }^{29}$ An important reason why financial liberalization had a larger impact in Asia than in Latin America in terms of financial depth is the higher degree of creditor protection granted by the legislation (Galindo, Micco and Ordoñez, 2002).
} 
The Latin American financial system is somewhat more bank-based than the Asian one and similar to that of Eastern Europe. Back in the early 1980s, the three regions were more bankbased but Asia was the first to start developing the stock market, and to a lesser extent the domestic bond market. The difference between Asia and the other two regions widened even more in the 1990s, a development driven in good part by the large capital inflows and the ensuing asset bubble. It should be noted that the growth of the capital markets in Asia did not hamper the development of the banking system. On the contrary, bank liquid liabilities grew much more in Asia than in Latin America or Eastern Europe in the last decade. The situation in 2000 confirms the general trend of a more developed and more balanced composition in Asia, after the collapse in 1997, and a smaller and more bank-based system in Eastern Europe and even more so in Latin America.

We now concentrate on the banking system and on measures of efficiency and soundness, rather than size (graph7). Latin America's performance is mixed. It ranks last in terms of efficiency, when measured by the relatively large net interest margin of its banking systems. As regards solvency, asset quality is better in Latin America than in Asia, probably as a consequence of the Asian crisis, but the risk-weighted capital ratio is higher in Asia.

G7 Banking sector soundness in emerging regions.

Profitability and solvency ratios (as percentage of total assets)

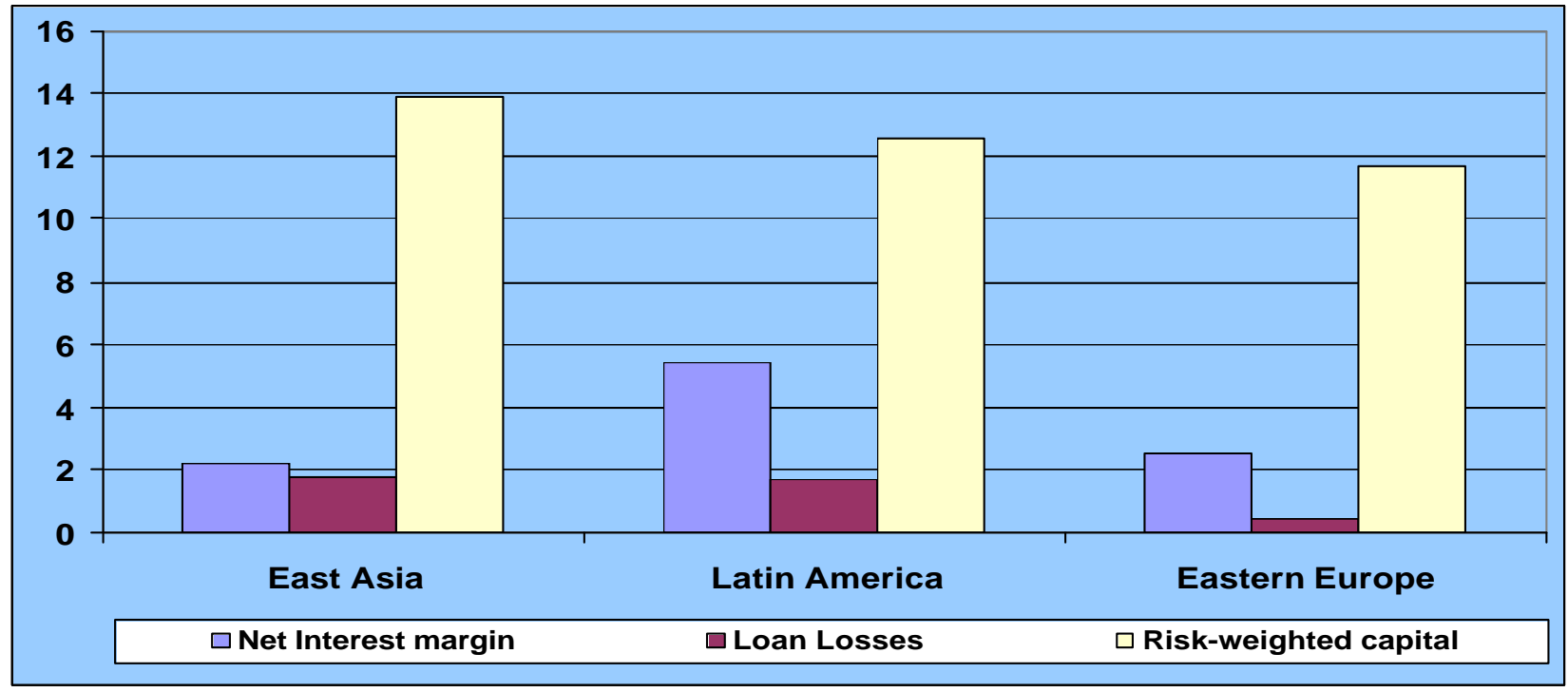

Data for 1999.

Source: Hawkins and Mihaljek (2001).

Latin America performs poorly in terms of bank credit to the private sector when compared with Asia but it is in a much better situation than Eastern Europe. In fact, Asia's private credit is twice that of Latin America and three times that of Eastern Europe (graph 8). Latin America 
experienced a collapse in private credit as a consequence of the debt crises, but the liberalization process of the 1990s led to a relatively rapid growth in private credit even if the level is still low.

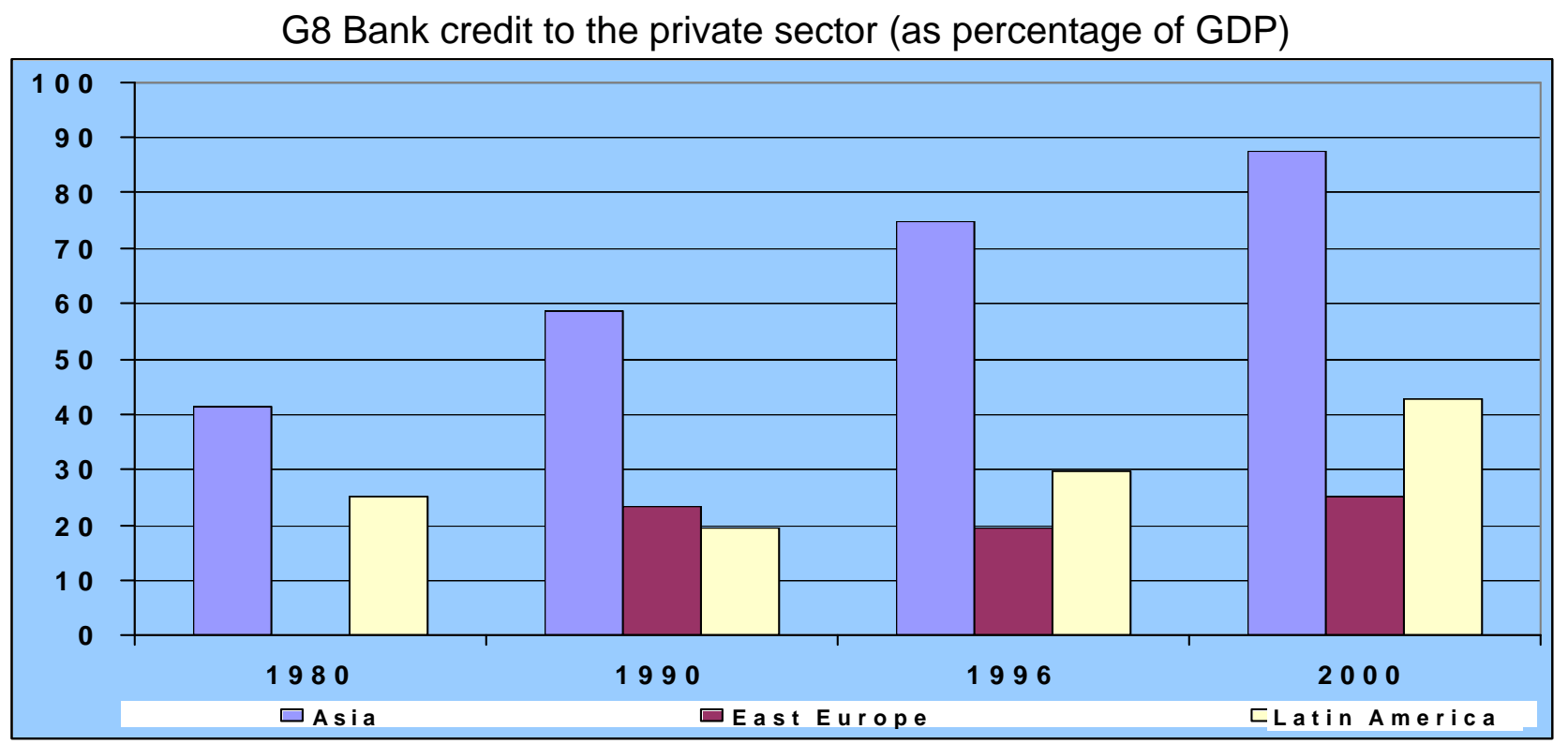

Source: IFS (2001).

G9 Real lending rates in emerging regions

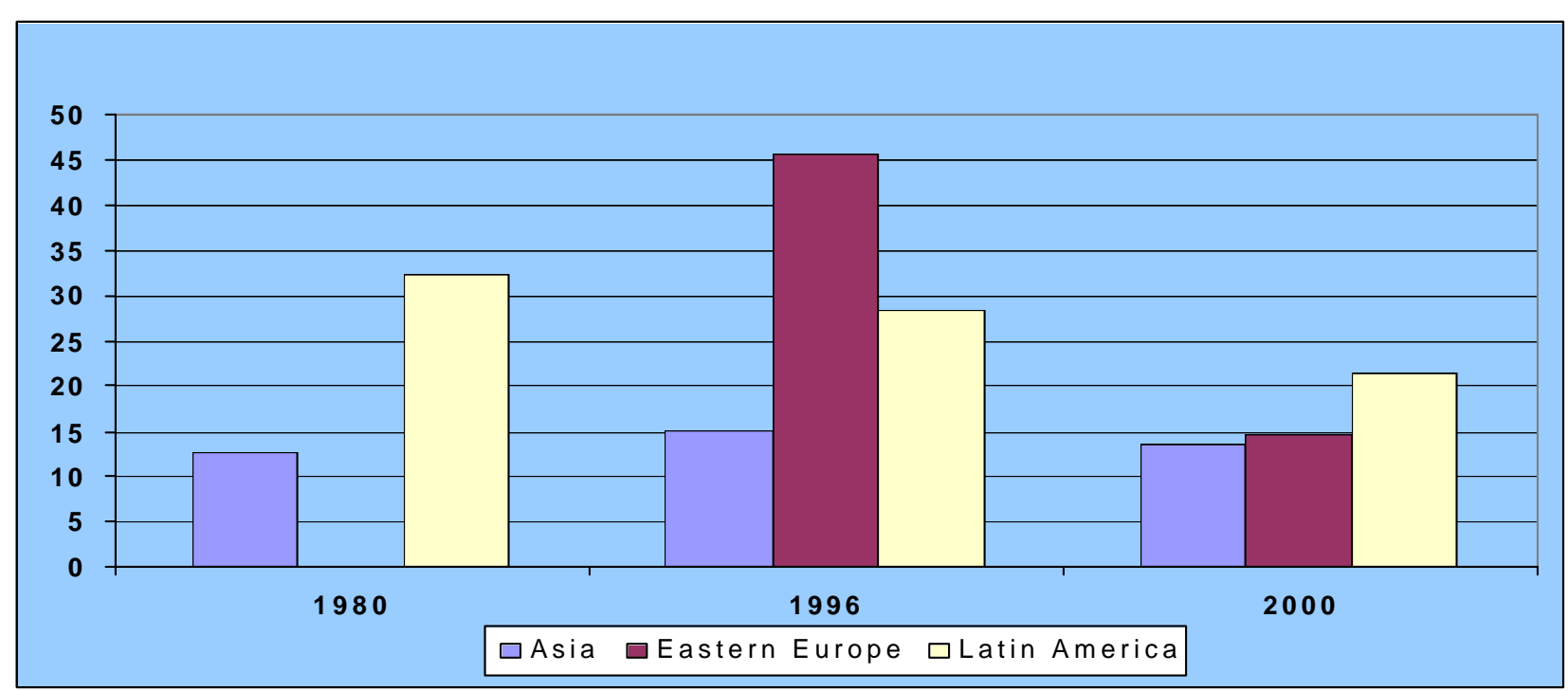

Source: IFS (2001).

Note: 1990 is not included because of the influence of outliers (hyperinflation countries).

One of the factors that may explain the relatively low levels of private credit in Latin America are the very high real lending rates (graph 9, above), which tend to deter demand. These, however, may also be determined by the region's difficult access to international capital 
markets, since very high returns are required to attract funds. In fact, if we exclude the very high real interest rates in Eastern Europe in the transition period, a situation which is not easily comparable, Latin America has consistently suffered from the highest real lending rates. Although decreasing, real lending rates still hover above $20 \%$ on average in the region, which must have a negative impact on the demand for private credit.

Banking systems in Asia, Eastern Europe and Latin America are also different in terms of the ownership of bank assets. Government ownership has shrunk over time in Latin America, as well as in Eastern Europe, to levels below 20\% of total assets (graph 10), although country differences are very large in this respect. Contrarily, government owned banks represent today close to $40 \%$ of total bank assets in Asia and there appears to be no change in trend ${ }^{30}$. Foreign participation is large in Latin America (40\% of total assets) but is much higher in Eastern Europe. In Asia, foreign ownership has fallen after the Asian crisis, to less than $10 \%$ of assets ${ }^{31}$.

G10 Bank ownership in emerging regions (as percentage of total assets)

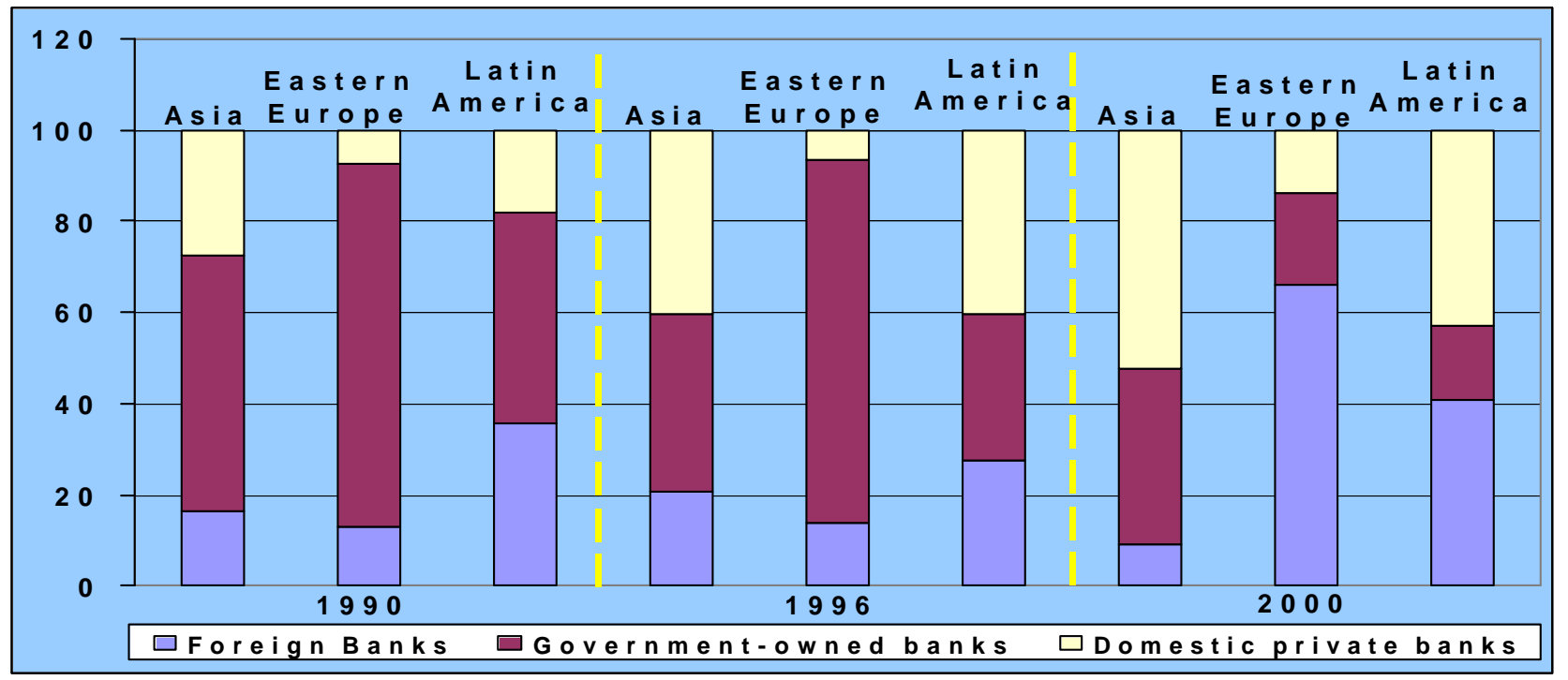

Source: Beck et al. (1999), La Porta, López-de-Silanes and Shleifer (2002) and Hawkins and Mihaljek (2001).

Note: A bank is defined as foreign if at least $50 \%$ of the equity is owned by foreigners. A bank is defined as public if at least $50 \%$ of the equity is held by the government or a public institution.

Finally, the concentration of the Latin American banking system has fallen substantially until 2000. In that year, an average of $40 \%$ of total assets were in the hands of the three largest

\footnotetext{
${ }^{30}$ Government ownership actually increased with the Asian crisis because of several bailouts, especially in Indonesia.

${ }^{31}$ For this purpose, we have excluded from our figures Hong Kong and Singapur, which hold a major share of foreign banks, because of their particular condition as international financial centers.
} 
banks, which is a much lower share than that prevailing in Eastern Europe and also somewhat lower than in Asia (graph 11).

G11 Bank concentration in emerging regions

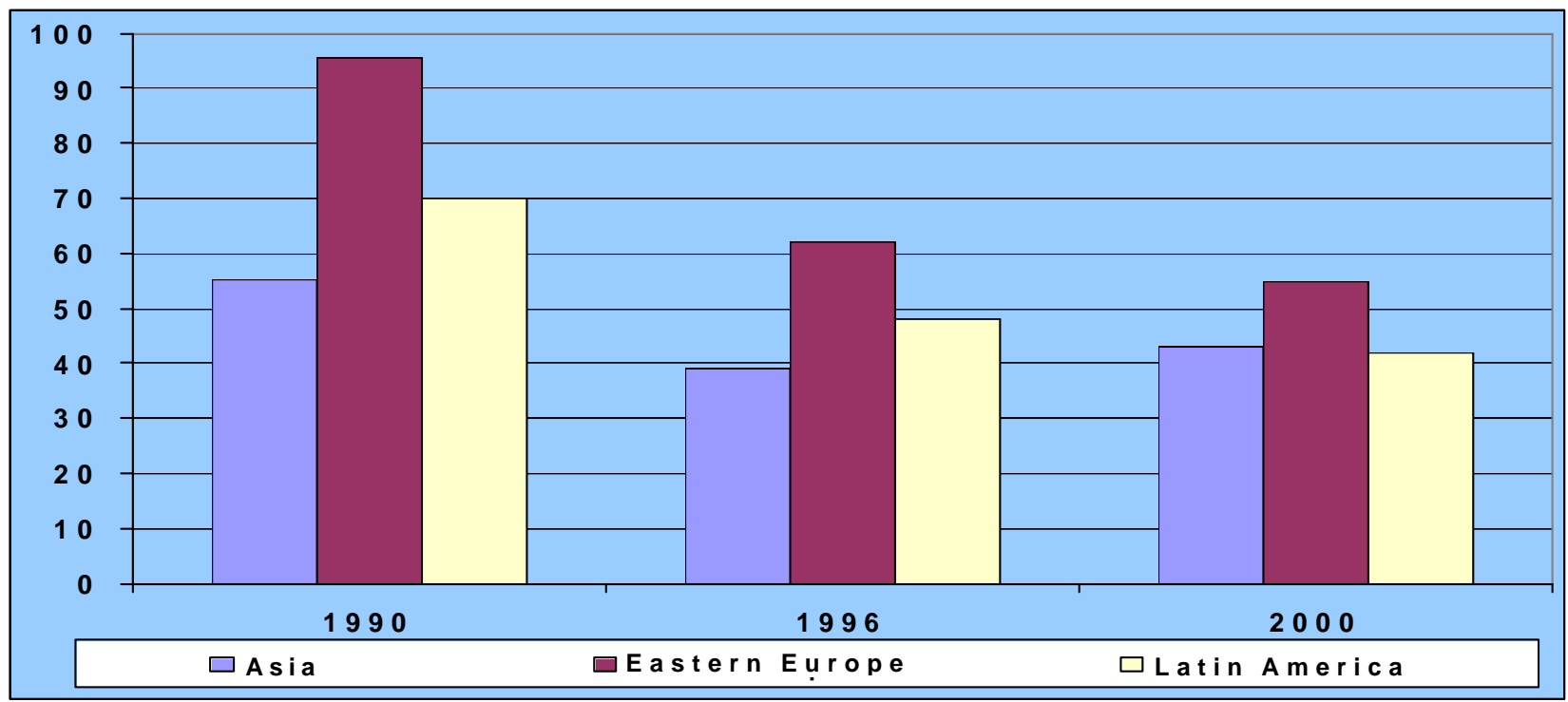

Source: Beck et al. (1999) and own calculations.

Note: Concentration is defined as percentage of the three largest banks' assets to total banking sector assets.

However, concentration appears to have risen rapidly after 2000 in a few Latin American countries.

Looking at the ownership structure and the concentration of the three regions, it appears that those financial systems which have reduced the share of state-owned banks and have increased foreign participation tend to have reduced concentration, contrary to what could have been thought. The relation between the two issues, though, is hard to determine, since no other factors have been taken into account.

As regards capital markets, Latin America stands very far from the situation prevailing in Asia and close to that of Eastern Europe. Latin American domestic debt markets - despite a decade of rapid development as will be seen in the next section - are still small compared to other emerging markets (graph 6 above), particular as regards private sector issuance. Bond issuance is still geared to the international markets where Latin American compares favorably with Eastern Europe and is similar to Asia ${ }^{32}$. The stock market in Latin America is only one fourth of Asia's, in terms of capitalization, even after the Asian crisis (graph 12).

${ }^{32}$ BIS (2002). 
G12 Stock market capitalization in emerging regions (as percentage of GDP)

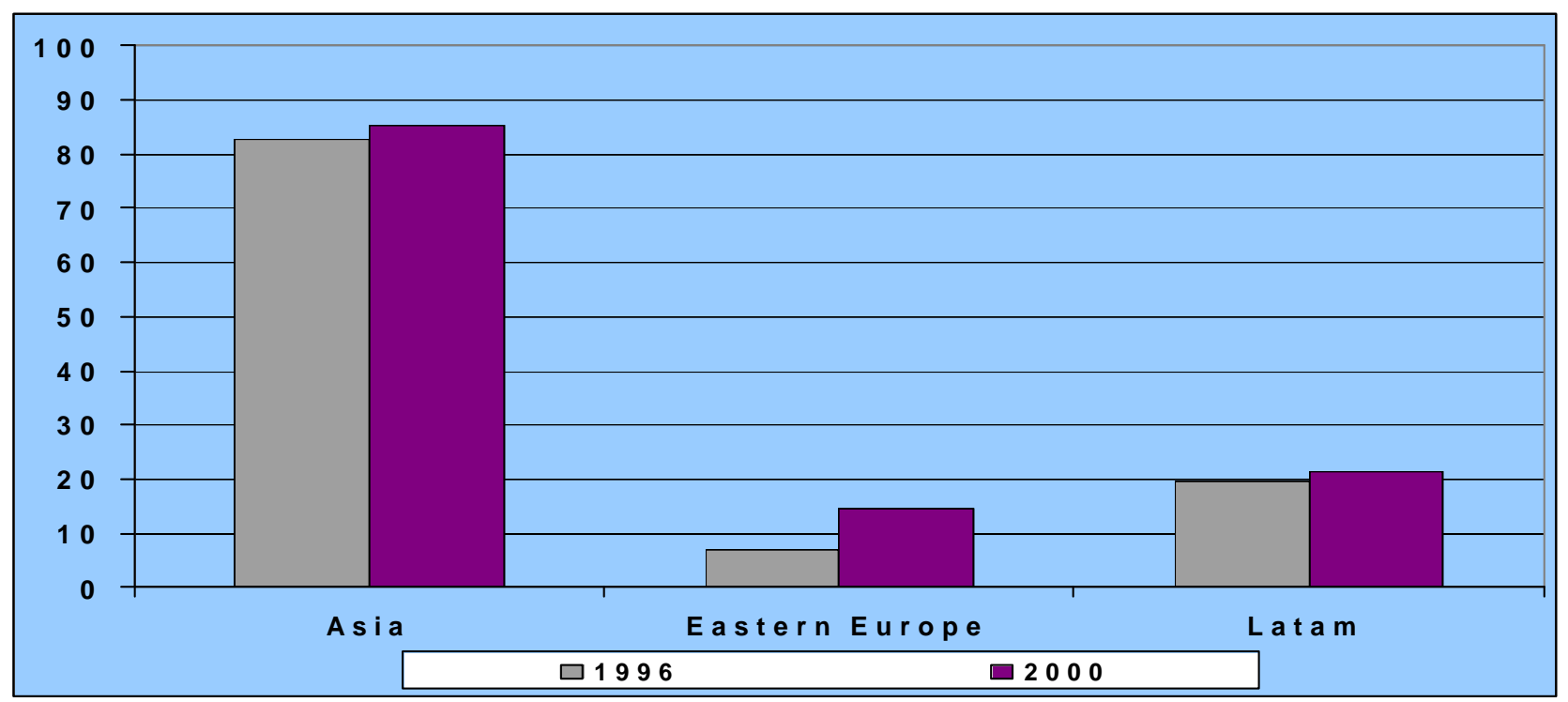

Source: Beck et al. (1999). For year 2000: IFS (2001), BIS (2001) and World Bank (2001c).

\section{Differences in financial development in Latin America: a country classification}

Virtually all Latin American countries have experienced stop-and-go financial liberalization processes, with ensuing crises in many of the cases. The sudden oil-related inflows of funds in the 1970s, channeled basically through foreign bank lending, allowed Latin American countries to finance large-scale import substitution projects and large budget deficits without the need to develop their banking systems. The debt crisis was accompanied by banking crises in some countries, which weakened further the basis for financial development. Eventually, successful stabilization programs, accompanied by a renewed liberalization process, led to fast bancarization. In addition, the Brady plan became an important catalyzer for the development of Latin American external debt markets.

Finally, the substantial privatizations carried out in most Latin American countries prompted new listings in local stock markets, which together with the liberalization of capital markets, increased their size and liquidity, albeit at still low levels for international standards.

After the brief description of the Latin American financial systems with a regional perspective, we now move to a more detailed analysis in which countries' differences are taken into account, at least to a certain extent. To this end, this section will classify 20 Latin American countries in relatively homogeneous clusters of countries with similar financial depth and per capita income. This will allow us to describe developments over time, taking into account the group differences, through stylized facts. 
G13 Financial depth in Latin America: cluster classification

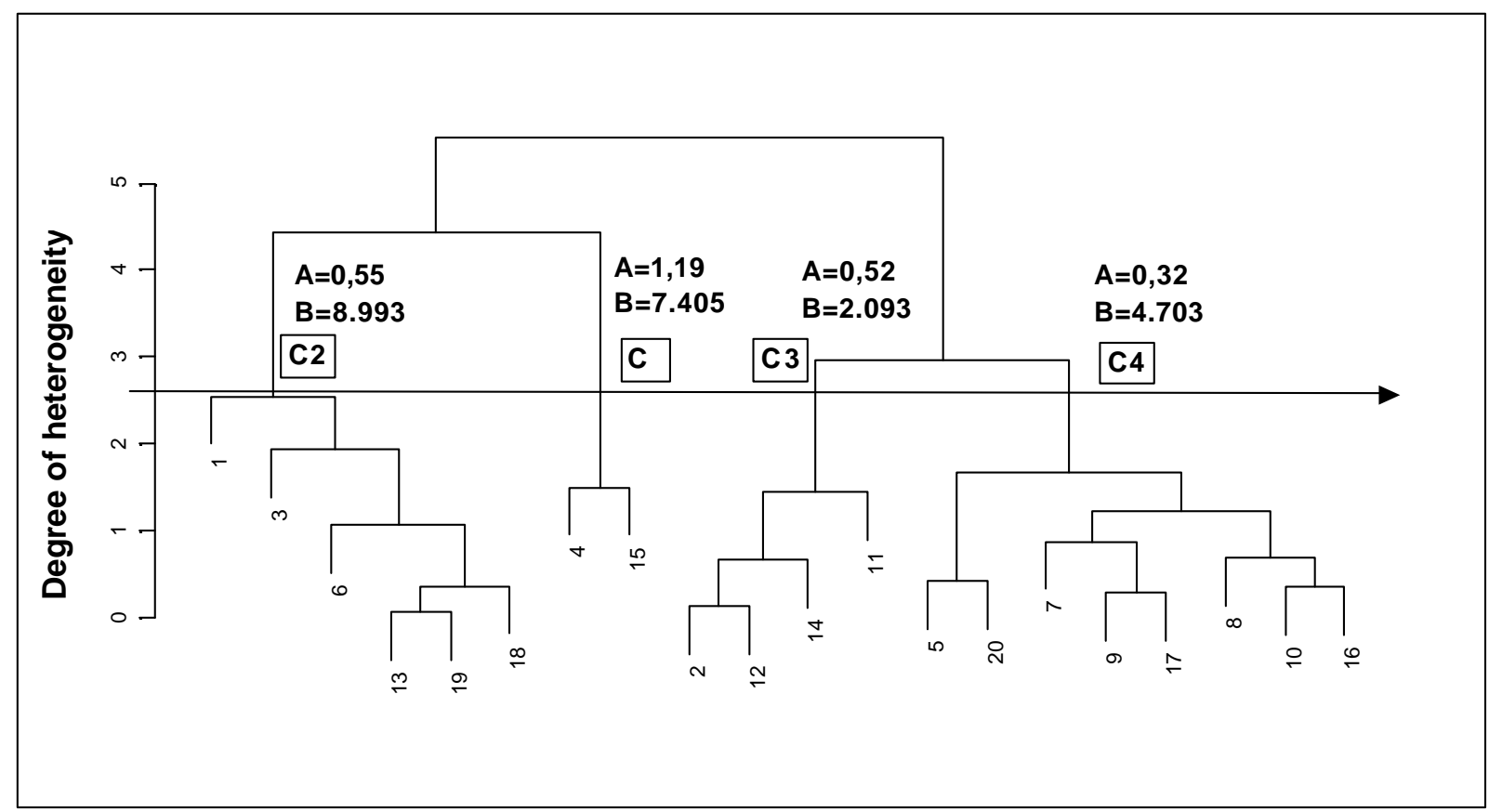

Data for 2000

(A) Financial depth

(B) GDP per capita

Source: IFS (2001), Bloomberg and national statistics.

Note: Financial depth is composed of bank liquid liabilities (M2), plus stock market capitalization, plus public and private bonds outstanding, all as percentage of GDP.GDP per capita is defined in PPP terms

$\begin{array}{cr}\text { CLUSTER } 1 \text { (C1) } & \text { Country Name } \\ \mathbf{N} & \text { Chile } \\ 15 & \text { Panama } \\ & \\ & \\ \text { CLUSTER 2 (C2) } & \\ \mathbf{N} & \text { Country Name } \\ 1 & \text { Argentina } \\ 3 & \text { Brazil } \\ 6 & \text { Costa Rica } \\ 13 & \text { Mexico } \\ 18 & \text { Trinidad and Tobago } \\ 19 & \text { Uruguay }\end{array}$

$\begin{array}{cr}\text { CLUSTER 3 (C3) } & \text { Country Name } \\ 2 & \text { Bolivia } \\ 11 & \text { Haiti } \\ 12 & \text { Honduras } \\ 14 & \text { Nicaragua }\end{array}$

CLUSTER 4 (C4)

N Country Name

$5 \quad$ Colombia

$7 \quad$ Dominican Republic

$8 \quad$ Ecuador

$9 \quad$ El Salvador

$10 \quad$ Guatemala

16 Paraguay

17 Peru

20 Venezuela 
The variables used are also the same: financial depth in its broad definition (bank liquid liabilities, stock market capitalization and domestic bonds outstanding), and per capita income in PPP terms with data for 2000. As a second step, we test for the robustness of the clusters identified to other definitions of financial depth and to the introduction of financial efficiency in the cluster analysis.

Four groups of comparable homogeneity are found. Cluster 1 comprises countries with high financial depth and middle-to-high GDP per capita, namely Chile and Panama ${ }^{33}$. Cluster 2 includes countries with somewhat lower financial depth and relatively high GDP per capita, i.e., Argentina, Brazil, Mexico, Uruguay, Trinidad and Tobago and Costa Rica. Cluster 3 is composed of countries with middle to low financial depth but which fare quite well given their very low income, i.e., Honduras, Haiti, Bolivia and Nicaragua. Finally, Cluster 4 represents the middle - and some low - income countries with low financial depth, namely El Salvador, Colombia, Dominican Republic, Ecuador, Guatemala, Paraguay, Peru and Venezuela ${ }^{34}$ (graph 13 , above) ${ }^{35}$. The last two clusters are the most homogeneous, followed by Cluster 1 . Cluster 2 is, as one would expect, the most heterogeneous. It should be noted that the correlation between financial depth and GDP per capita is lower in this second cluster analysis, concentrated on Latin American countries, than in the worldwide one: $53 \%$ for Latin America compared to $66 \%$ worldwide. This means that the weight of other factors that explain financial depth-different than GDP per capita- is larger for Latin American countries. (graph 14).

A robustness exercise is conducted, given that this cluster classification is based on one of the aspects of financial development only (size and not efficiency). Because of the absence of a reliable indicator of global financial efficiency, only the banking system is included in this second cluster analysis. Financial efficiency is, thus, proxied by the net interest rate margin, ${ }^{36}$ and bank assets ${ }^{37}$ stand for financial depth. The same variable is used for per capita income. The results confirm the position of countries in the previous cluster in $65 \%$ of the cases. Size and efficiency are, therefore, not fully correlated but there

\footnotetext{
${ }^{33}$ The fact that Panama has an off-shore financial sector advices against using this country as the best representative of the most financially developed group.

${ }^{34}$ Data on domestic bond markets outstanding has been included for the main countries (Chile, Argentina, Brazil, Mexico, Uruguay, Colombia, Peru, Venezuela, Trinidad and Tobago, Costa Rica, Honduras and Ecuador). The size of the other markets is probably too small to change the cluster classification.

${ }^{35}$ At this point one must again recall the limitations facing any cluster analysis like the one we are conducting. The heterogeneity of Latin American financial systems may render some of the conclusions valid for an "average" country in a cluster but not individually for each of the countries comprising that group.

${ }^{36}$ The net interest margin is the interest revenue minus financial costs as a percentage of total assets.

${ }^{37}$ The choice of bank assets - rather than bank liabilities as in the previous exercise - gives consistency to the variable chosen for efficiency.
} 
is a close link between them, which allows us to use the previously found clusters with some more assurance for the description of stylized facts.

G14 Scattered plot of financial depth and GDP per capita in Latin America

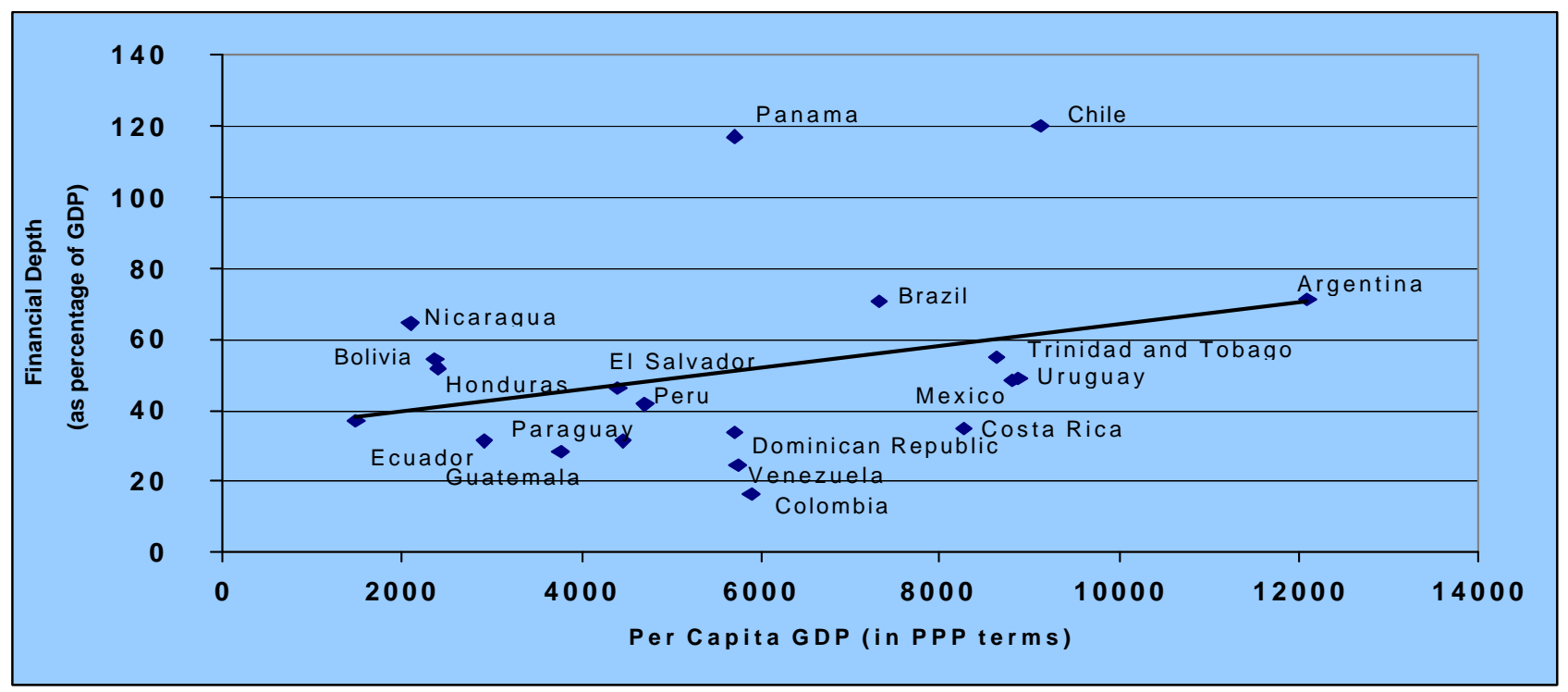

Data for 2000.

Source: IFS (2001), Bloomberg and national statistics.

\section{Stylized facts for Latin American countries}

\subsection{Financial depth}

Differences among Latin American financial systems appear clearly when comparing their size. They range from levels over $100 \%$ of GDP in Chile and Panama to levels below $40 \%$ in the least financially developed group (Cluster 4, marked as C4 in graph 15).

\section{G15 Financial depth in Latin America}

Total financial assets (as percentage of GDP)

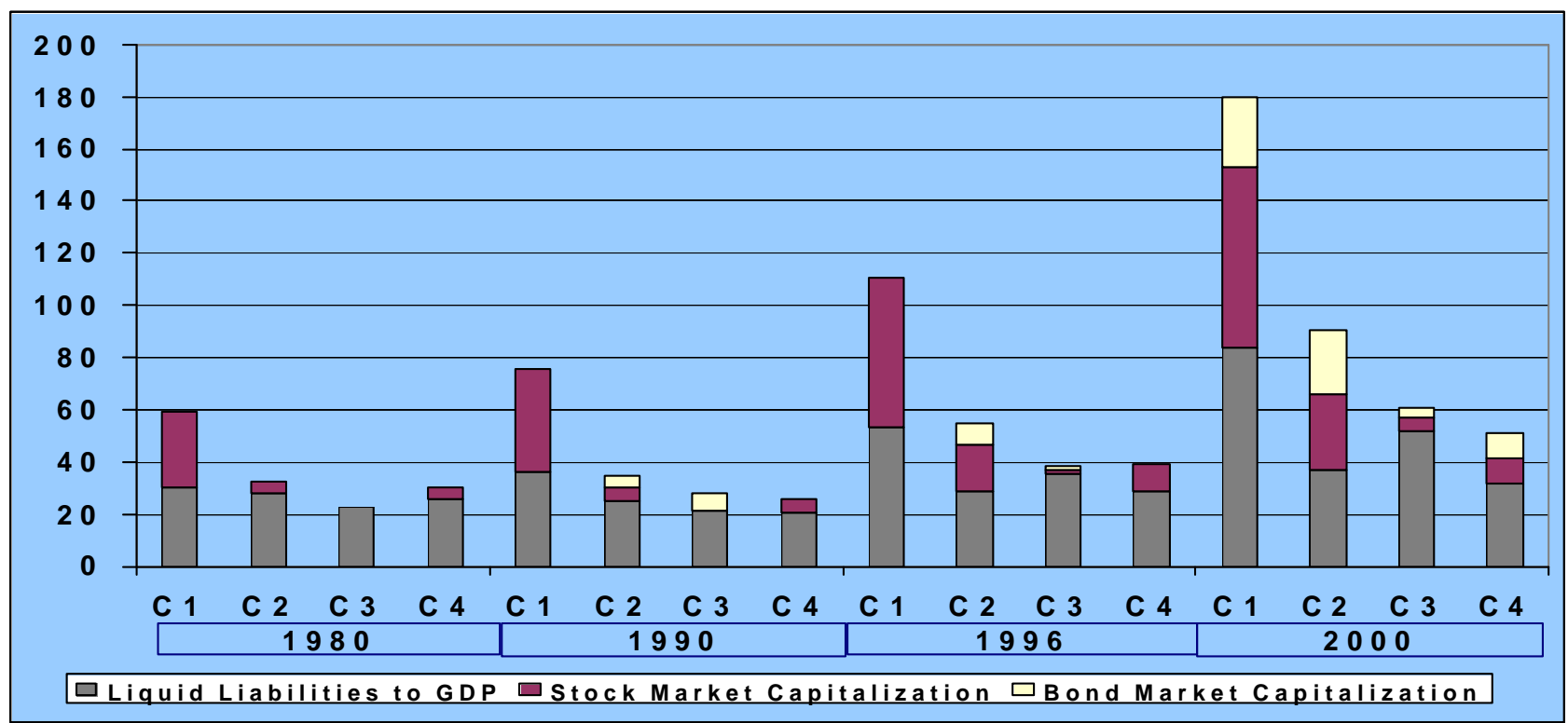

Source: Beck et al. (1999), IFS (2001) and World Bank (2001a).

Note: 1 stands for bank liquid liabilities. 2 stands for stock market capitalization. 3 stands for bonds outstanding. 
For the rest of the countries, financial depth falls in the range of $40-80 \%$ of GDP which, as was shown in the previous section, is extremely low relative to Asia and comparable with Eastern European levels. In addition, the evolution of financial depth over time has also been different among countries. While very dynamic in Cluster 1 , especially during the first half of the 1990s, it has been markedly slower in Cluster 4, Clusters 3 and 2 staying somewhere in the middle.

\subsection{Financial structure}

Another interesting finding relates to the breakdown between the banking system and the capital markets. The most financially developed group (C1) is also the one with a more balanced structure. The rest continue to be bank-oriented although the weight of bank assets has fallen in the last few years, except in the lowest income group (C3) (graph 16).

G16 Financial structure in Latin America.

Ratio of bank liabilities to stock market capitalization and bonds outstanding

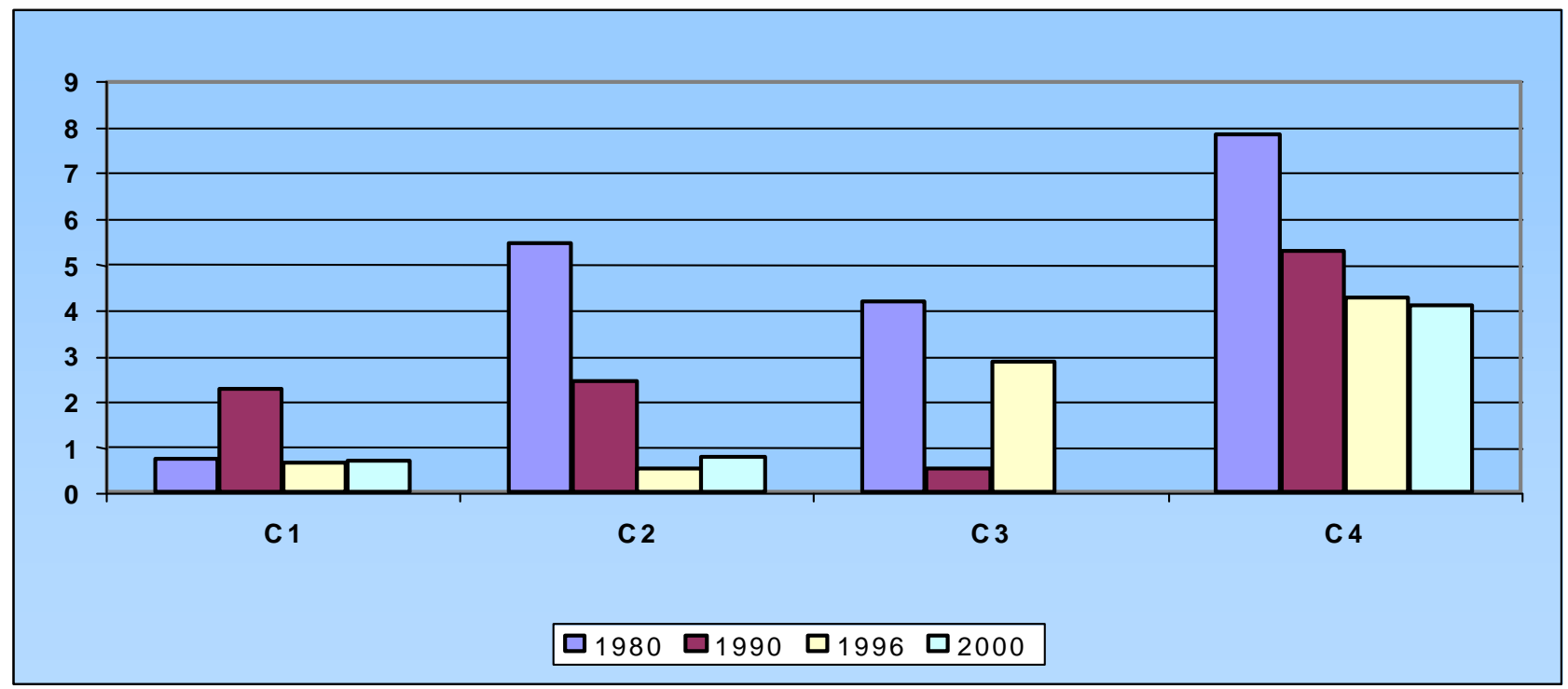

Source: Beck et al. (1999) and IFS (2001).

While this result is in line with the above reviewed literature, it is difficult to determine the causality. It may well be that only larger financial systems can afford a more balanced composition of the different markets or, else, that diversification fosters financial depth. This is one of those cases where a virtuous cycle may be present although it is hard to determine the order of events to achieve it.

\subsection{The banking sector}

After the "lost decade" of the 1980s, also for banking, Latin American banking systems have progressed substantially in the 1990s. In the early 1990s, countries liberalized their 
banking system almost completely and capital controls were lifted in virtually all cases. ${ }^{38}$ The large international banks which had left the region after having experienced large losses in wholesale syndicated loan markets due to the debt crisis, started to come back. They mainly undertook investment banking activity and, to a lesser extent, retail banking. New banks joined the latter, mainly through the acquisition of local banks in the large-scale privatization processes that took place in most banking systems of the region, and operated as universal banks. ${ }^{39}$ Smaller specialized banks have also found a niche in this framework. As regards investment banking, activity is concentrated around a group of international banks located at the large global financial centers ${ }^{40}$.

Although financial stability still depends on volatile macroeconomic conditions, Latin American banks today are very different from ten years ago. In this section, we look into the banking sector in more detail, assessing its basic composition, efficiency, ownership structure and concentration, and explore some of the factors that may explain the relatively low availability of bank credit to the private sector in the region.

\subsubsection{Bancarization versus cash}

An important aspect of financial depth, for emerging countries, and even more so for the least developed countries, is what proportion of the liquid liabilities of a country is intermediated by banks, in other words how large bank deposits are compared to cash.

G17 Bancarization in Latin America

Bank deposits (as percentage of GDP)

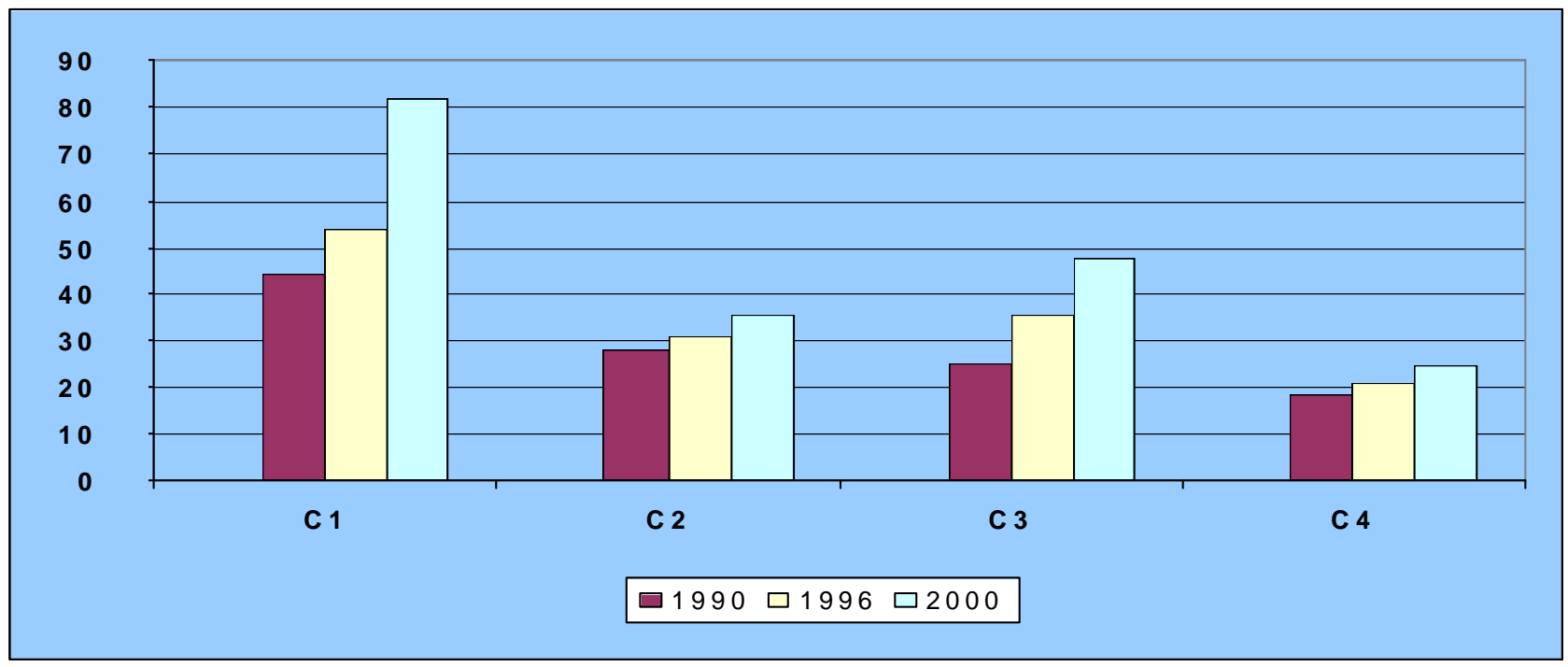

Source: IFS (2001).

Note: Bank deposits are obtained as the difference between M2 and cash in domestic currency.

${ }^{38}$ Chile lifted its own controls during the Asian crisis.

${ }^{39}$ See Goldman Sachs (2002) and Salomon Smith Barney (2001a, 2002a and 2002b).

${ }^{40}$ Brazil had a substantial national component in its investment banking industry at the start of the 1990s that has since been largely acquired by larger foreign organisations. 
As one would expect, the group of most financially developed countries (C1) is also the one that records more bancarization (measured as M2 minus cash, as percentage of GDP) and also the one having the biggest increase over time (graph 17, above). Cluster 2 shows very low levels of bank deposits as a share of GDP, in addition to a surprising stagnation over time. This would point to the fact that a relatively successful financial deepening has been achieved in these countries despite either widespread use of cash, or low bancarization levels, or both, something that could obviously hold implications in terms of how efficiently resources are mobilized. Finally, countries in Cluster 3, with relatively lower financial depth, show a promising increase in bancarization, while the bancarization of Cluster 4 has almost stagnated.

\subsubsection{Size of central bank assets compared to the banking system}

Central bank participation in the financial intermediation process has been documented to hold a negative relation with financial sector development. This should be relatively more important for very underdeveloped countries with overarching central banks which offer credit to the private sector for long-term investment. In the case of Latin American countries, as one would expect, there is clearly less central bank involvement over time (graph 18). There are also relatively more central bank assets in the poorest group of countries in terms of income per capita (C3).

G18 Ratio of central banks' assets to commercial banks' assets (as \% of GDP)

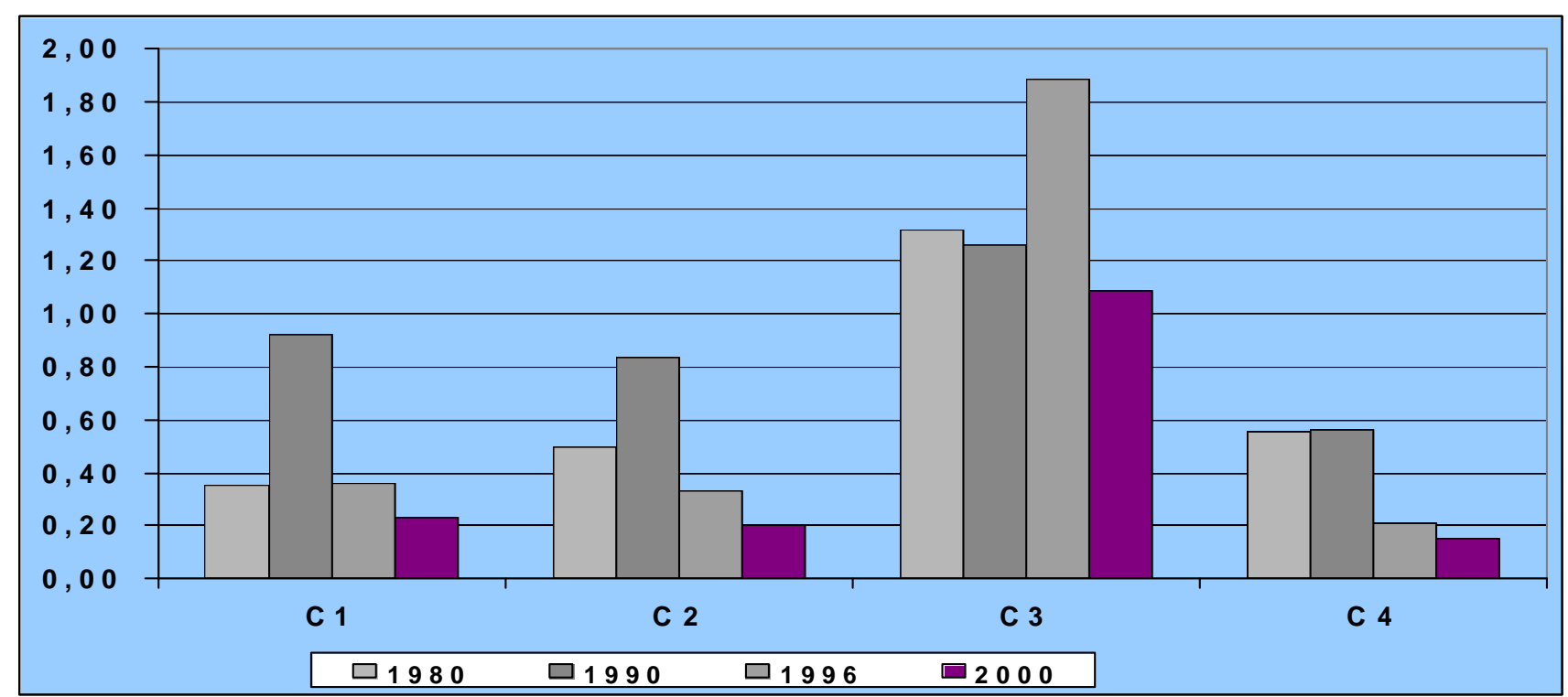

Source: Beck et al. (1999) and IFS (2001).

Note: Total bank assets are the sum of commercial bank and central bank assets. 


\subsubsection{Bank efficiency}

Bank efficiency measured by the inverse of the net interest margin, is higher in the countries belonging to the most financially developed countries, particularly Chile an Argentina (graph 19). Although still large, since 1997 net interest margins have fallen substantially in Venezuela, Peru and Colombia showing efficiency gains.

G19 Profitability and efficiency: the net interest margin in selected Latin American countries

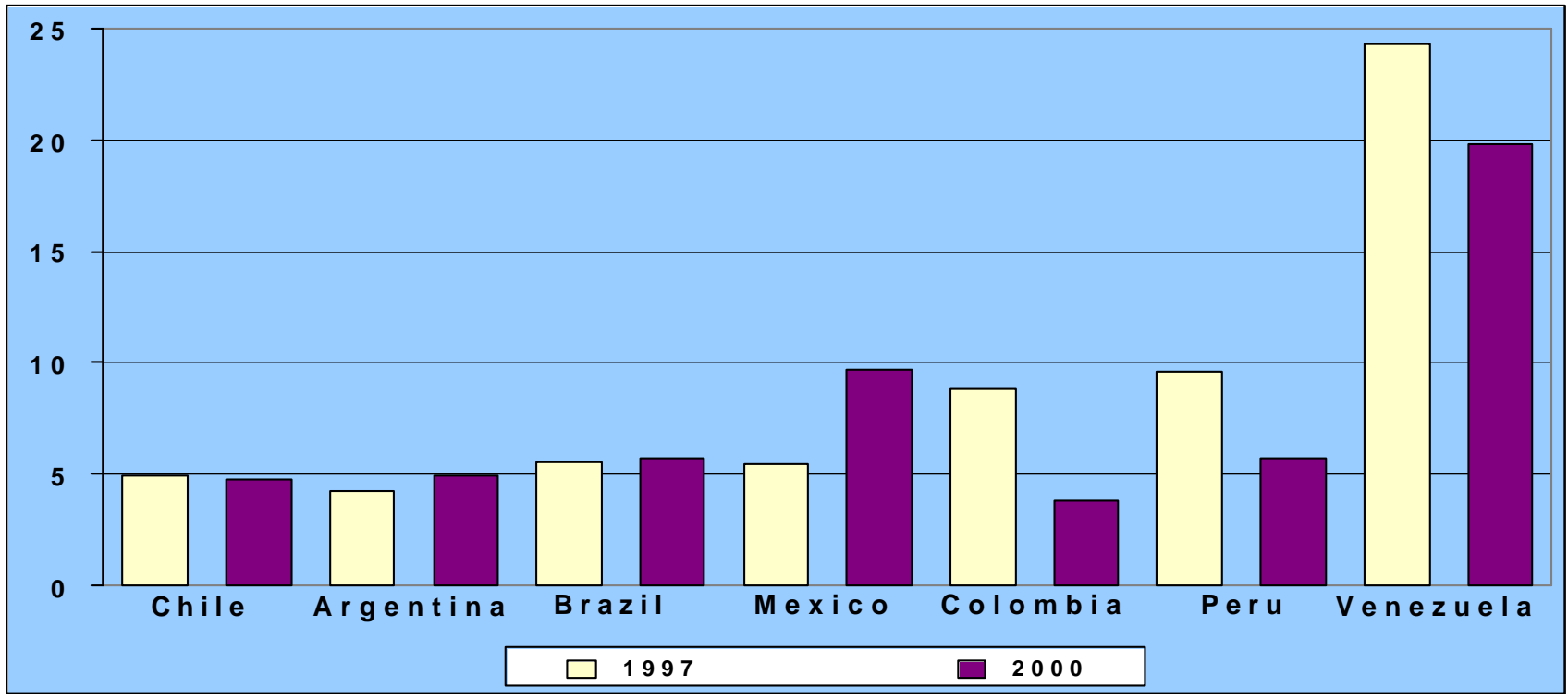

Source: Moodys (2000 and 2001) and Salomon Smith Barney (2001b and 2002a).

Note: The net interest rate margin equals interest income minus interest expense divided by total risk assets.

G20 Bank efficiency and bank depth in Latin America

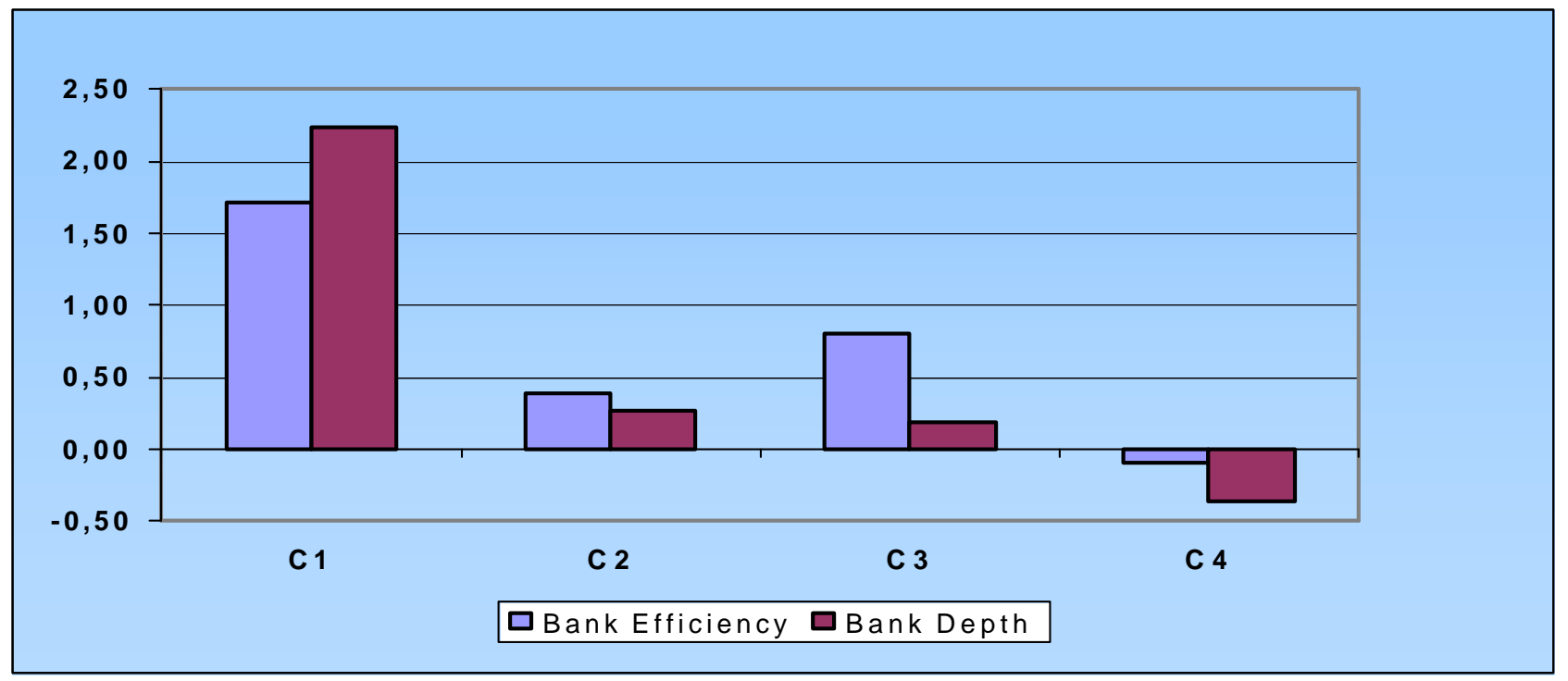

Source: Beck et al. (1999) and IFS (2001).

Note: The bars reflect the difference between each cluster and the mean. The inverse of the net interest margin is used as a proxy for bank efficiency. Variables are standardized. Each bar represents the average normalized distance of the countries in the cluster with respect to the mean of the total sample. 
The size and efficiency of the Latin American banking systems are now compared among groups of countries (graph 20, above). Size is measured by bank assets and efficiency by the inverse of the net interest margin for the year $2000^{41}$ and normalized using the median of all clusters. Bank size and efficiency broadly go hand in hand although the correlation is not very high, particularly in Cluster 3 where efficiency is low when compared to the relatively large size of the banking system, and would even be lower if we took a different definition of efficiency, such as interest rate spreads. ${ }^{42}$

\subsubsection{Bank credit to the private sector}

The generally low level of credit to the private sector found for the region, is confirmed when moving to a country comparison, except for the most financially developed group (C1). This cluster more than doubles the amount of private credit of Clusters 2 and 3 (graph 21), and nearly triples that of Cluster 4.

G21 Bank credit to the private sector in Latin America (as percentage of GDP)

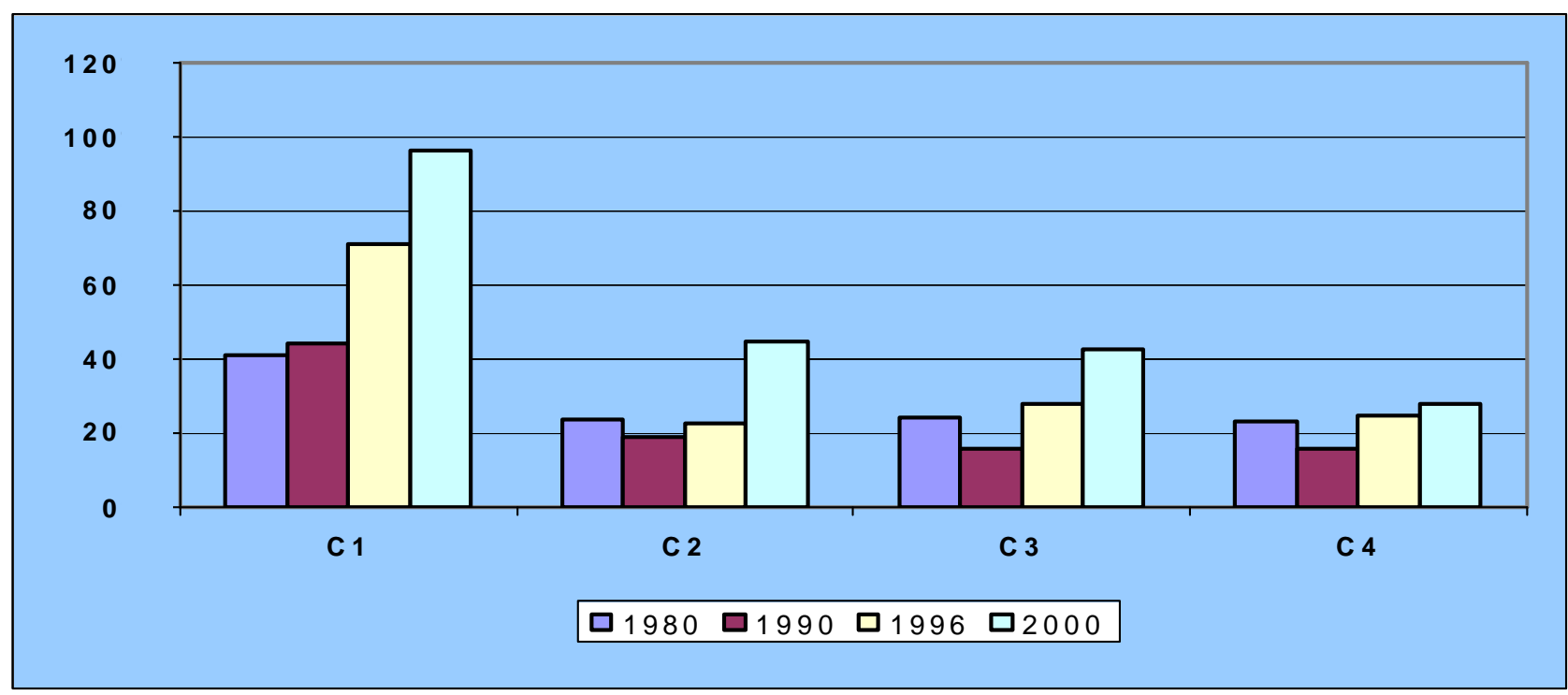

Source: Beck et al. (1999) and IFS (2001).

Private credit is not scarce in most countries but generally has an average short-term maturity, which increases vulnerability and, therefore, the positive impact of private credit on growth. Chile and Brazil are the countries reviewed with the largest share of long-term private credit (graph 22), which belong to the first and second most financially developed clusters ( $\mathrm{C} 1$ and $\mathrm{C} 2$, respectively).

\footnotetext{
${ }^{41}$ The inverse is calculated so that both indicators have the same sign since higher margins imply lower efficiency.

${ }^{42}$ For the sake of robustness, the net interest margin was compared with the spread between deposit and lending rates. Cluster 3 appears as less efficient than Cluster 4 in terms of interest rate spreads. However, Cluster 2 performs very poorly.
} 
G22 Short and long term credit to total credit in selected Latin American countries

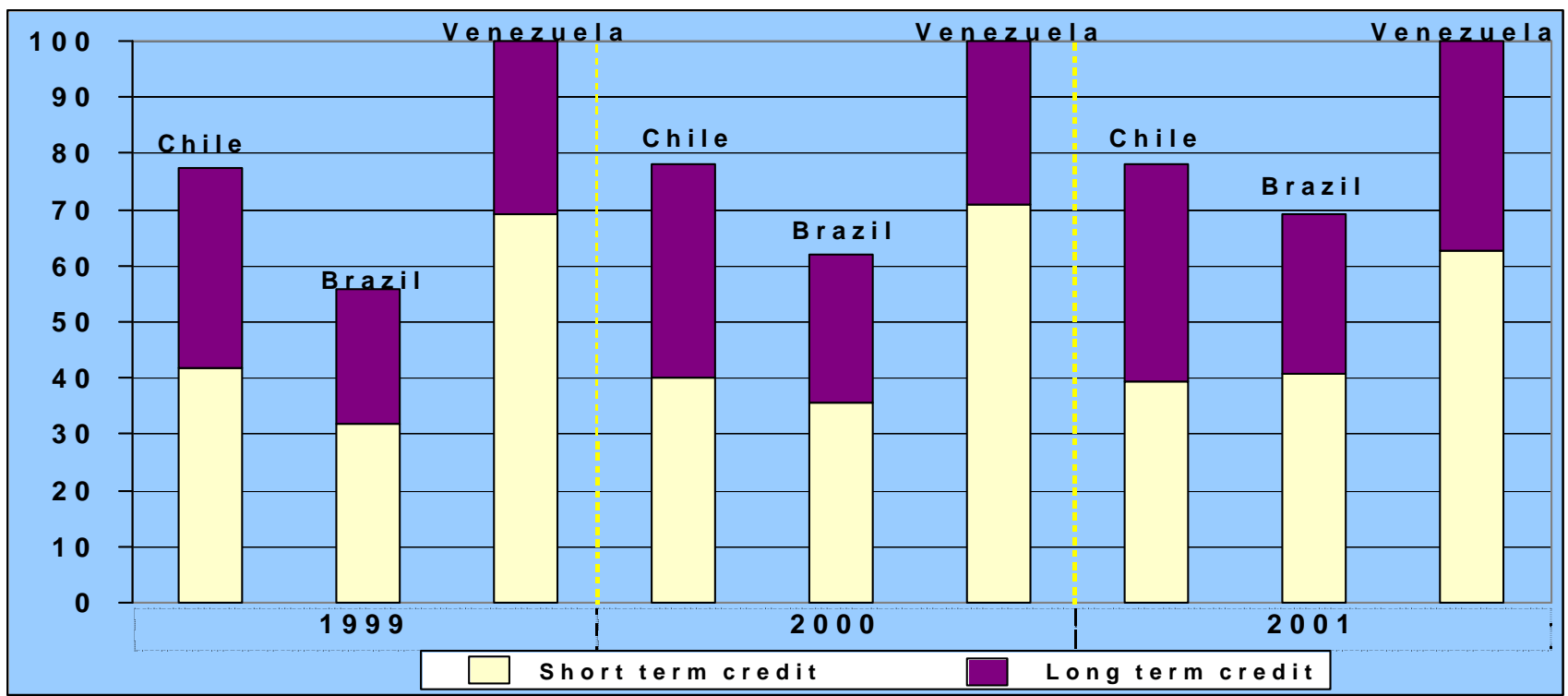

Source: Moodys (2000 and 2001) and national supervisory authorities.

Note: Totals of Chile and Brazil do not add up to $100 \%$ due to other items classified under total credit not included in short and long term credit.

G23 Non-performing loans and private credit in selected Latin American countries

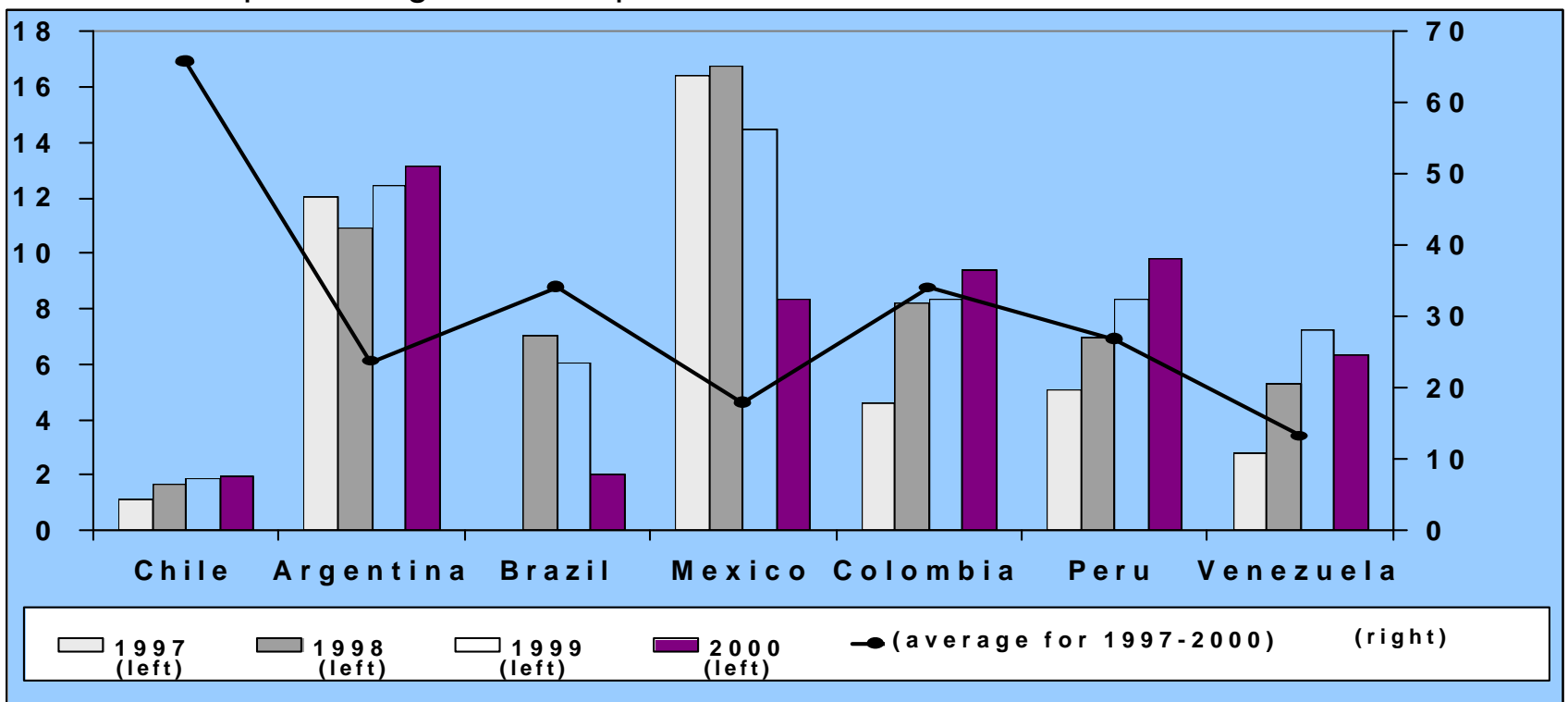

Non-performing loans (NPL) as percentage of total credit (in bars).

Bank credit to the private sector as percentage of GDP (in line).

Source: Moodys (2001) and IFS (2001).

In addition, some countries, particularly those of the least financially developed group (C4) and Argentina and Mexico (C2), have relatively large amounts of non-performing loans, reducing the amount of private credit which is intermediated efficiently (graph 23, above $)^{43}$.

${ }^{43}$ Although the situation has substantially improved in the last two years, the significant size of Mexico's share of non-performing loans relative to total credit prompted the central bank to publish a series of private credit which excluded non-performing loans (graph 23). 
Given the importance that the scarcity of private credit has for the growth prospects of the region, we focus now on the main reasons which may explain it.

Several conclusions can be drawn, from the review of the evolution of private credit and bank liquid liabilities over the last forty years and the occurrence of financial liberalization and banking crises in several Latin American countries (graph 24). Financial liberalization ${ }^{44}$ boosted bank credit to the private sector in most countries, which increased in terms of its ratio to GDP, and tended to reduce the gap between liquid liabilities and private credit (see Argentina, Brazil, Chile, Mexico or Peru). The counter-examples are Costa Rica and Venezuela in the 1988 liberalization. The gap between liquid liabilities and private credit shrank faster in countries where financial liberalization was accomplished at an earlier date such as Chile. In this country, private credit even exceeded liquid liabilities, which can be taken as an indicator of efficient intermediation. Finally, financial liberalization started rather late in Costa Rica but also in Peru. While the former did not suffer from any banking crisis, the latter did suffer one, coupled with the debt crisis. In both countries private credit has lagged substantially behind liquid liabilities, but Peru is closing the gap much faster.

Banking crises led to a credit crunch in a few countries. This happened in Mexico after the 1994 crisis, when bank credit to the private sector halved from over $30 \%$ of GDP to less than $15 \%$ in the three subsequent years: It also fell, although to a lesser extent, in Venezuela and Peru, while it stagnated in others. In most countries credit to the private sector lagged the growth of liquid liabilities. This is the case at least in those countries were the banking crisis was not accompanied by a sharp deposit run. Mexico in 1994 again provides a good case in point, but also Argentina in 1995, Brazil in 1993, and Colombia. The counter-example is Chile, where credit to the private sector relative to GDP was hardly affected or tended to recover strongly soon after the crisis ${ }^{45}$. Only a few banking crises were associated with deposit runs (Argentina in 1991 and Venezuela in 1994), and thus with a rapid reduction in financial depth. In the remaining countries, liquid liabilities to GDP either stagnated or even continued to grow.

\footnotetext{
${ }^{44}$ We have borrowed these dates from Demirguc-Kunt and Detragiache (1998) which reflect interest rate liberalization dates.

${ }^{45}$ An explanation offered by Galindo and Micco, (2002) is that creditor rights were better protected in Chile, which allowed Chile to suffer less from the banking crisis shock, as well as from other external shocks.
} 
G24 Financial liberalization, banking crises and financial depth in selected Latin American countries

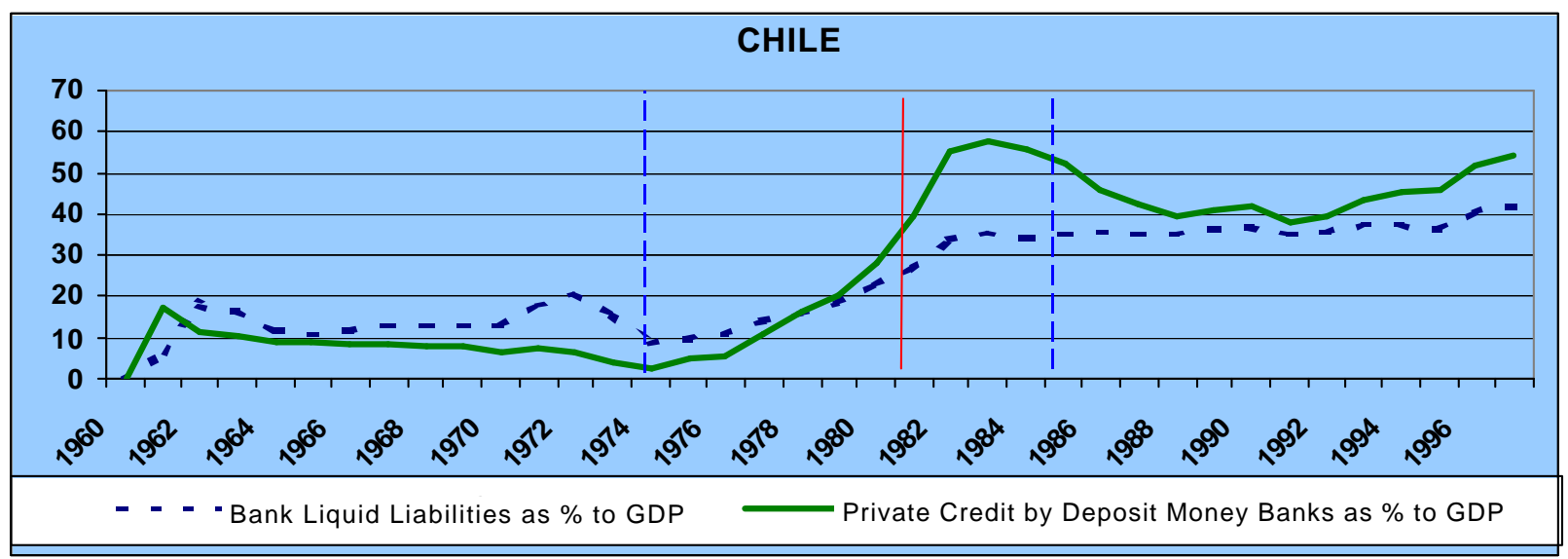

ARGENTINA

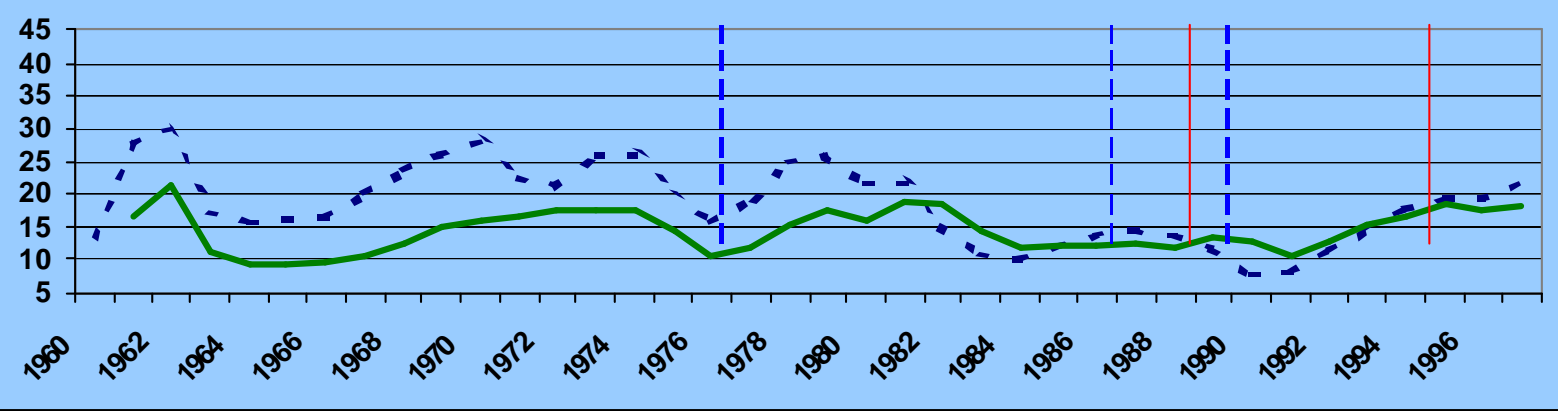

BRAZIL

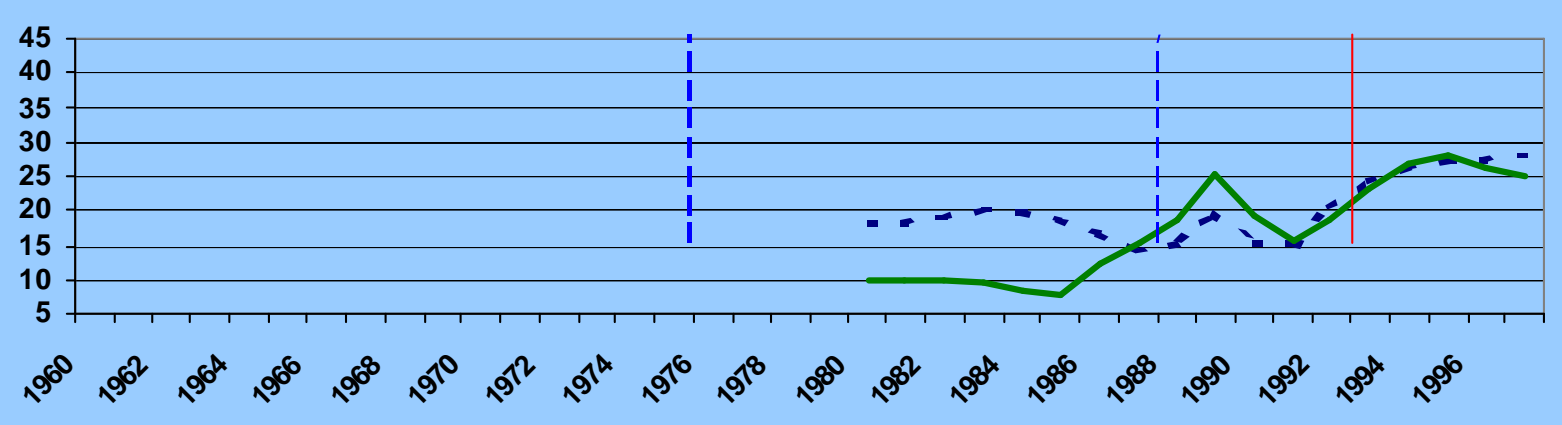

COSTA RIA

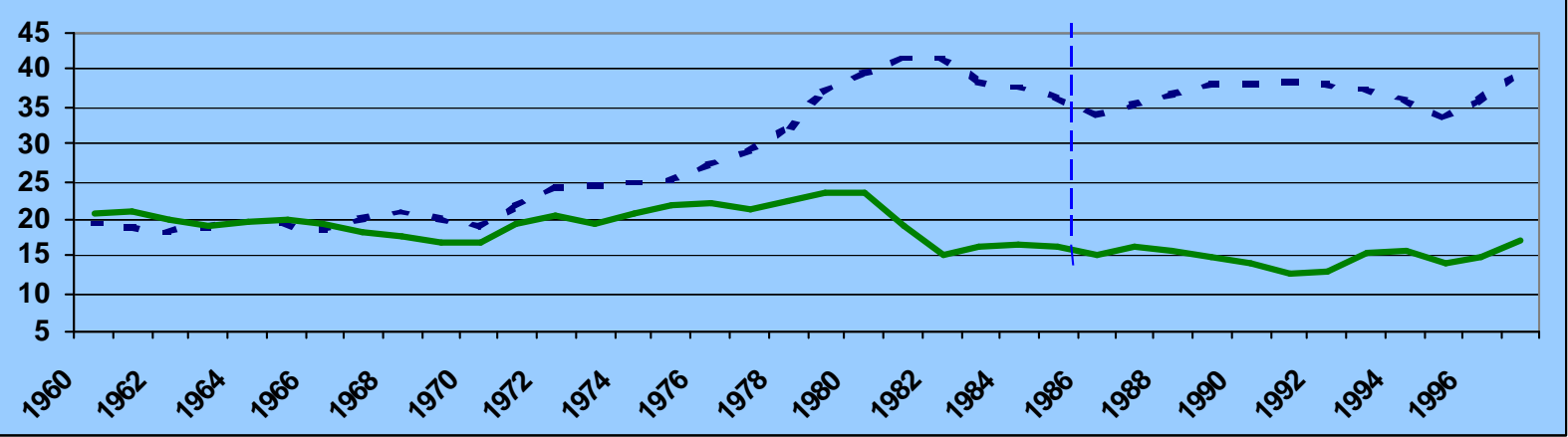

Source: Beck et al. (1999)

Note: The dotted vertical lines show the start of the liberalization process and the continuous vertical lines show the start of a banking crisis.

BANCO DE ESPAÑA / DOCUMENTO DE TRABAJO № 0216

36 
G24 Financial liberalization, banking crises and financial depth in selected Latin American countries
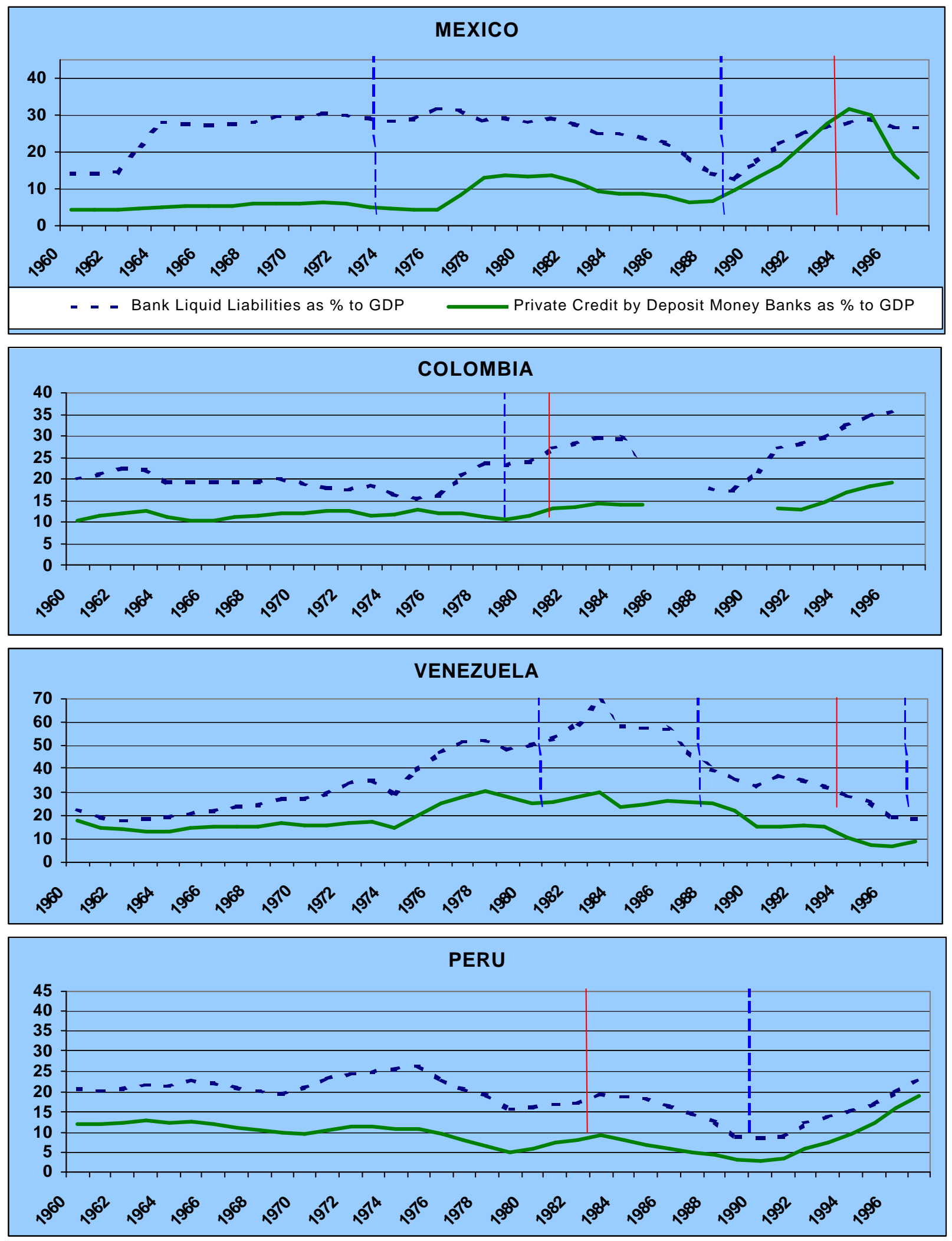

Source: Beck et al. (1999)

Note: The dotted vertical lines show the start of the liberalization process and the continuous vertical lines show the start of a banking crisis. 
Banking crises, and economic slowdowns in general, have led to mounting non-performing loans (NPLs), reducing the amount of loanable funds. This is particularly the case in Argentina, and to a lesser extent Peru.

The strengthening of bank regulation and supervision, especially bank capital requirements and loan provisioning, which has taken place in most Latin American countries in the last few years ${ }^{46}$ may also have hampered banks' predisposition to lend although its effect should be temporary (graphs 25 and 26).

G25 Risk-weighted capital ratio in selected Latin American banking systems

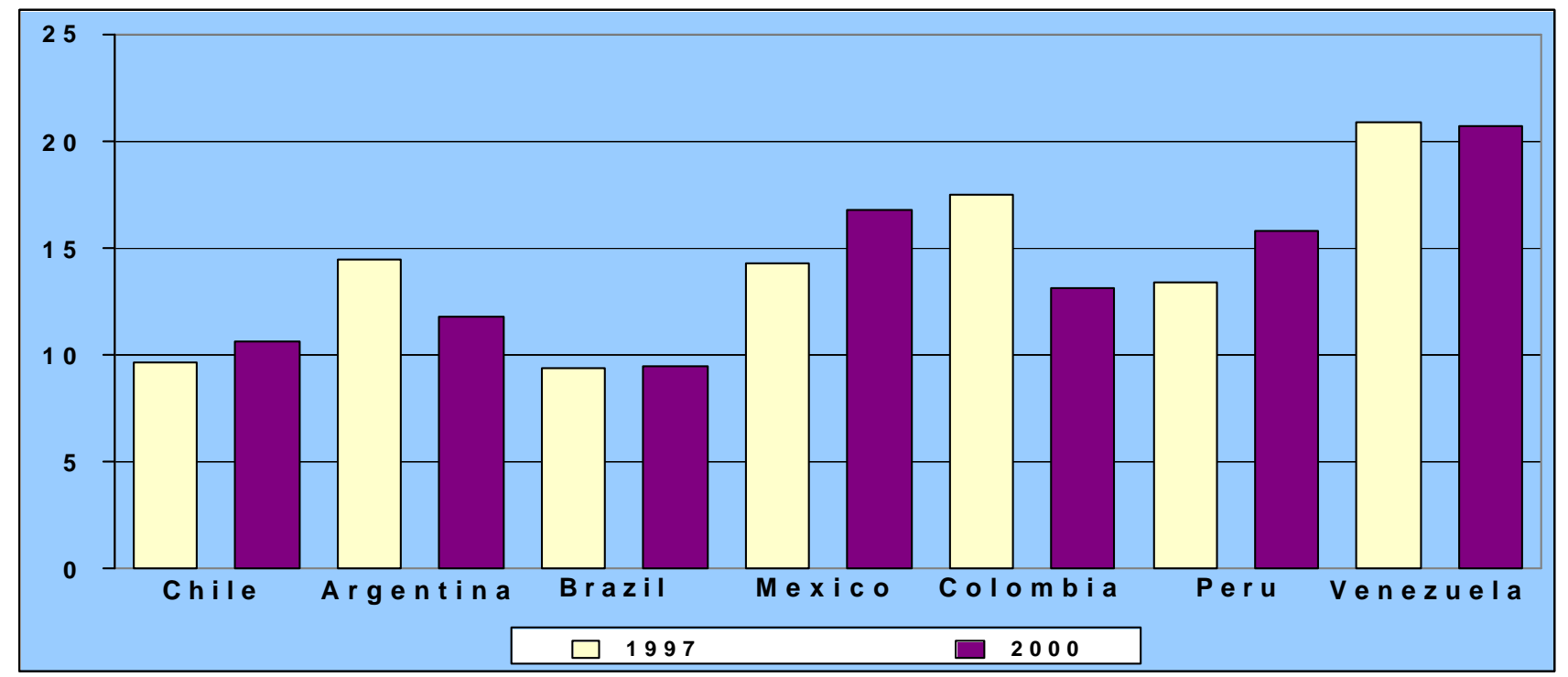

Source: Moodys (2001) and Salomon Smith Barney (2000, 2001b and 2002a).

G26 Loan loss provisioning to total loans in selected Latin American banking systems

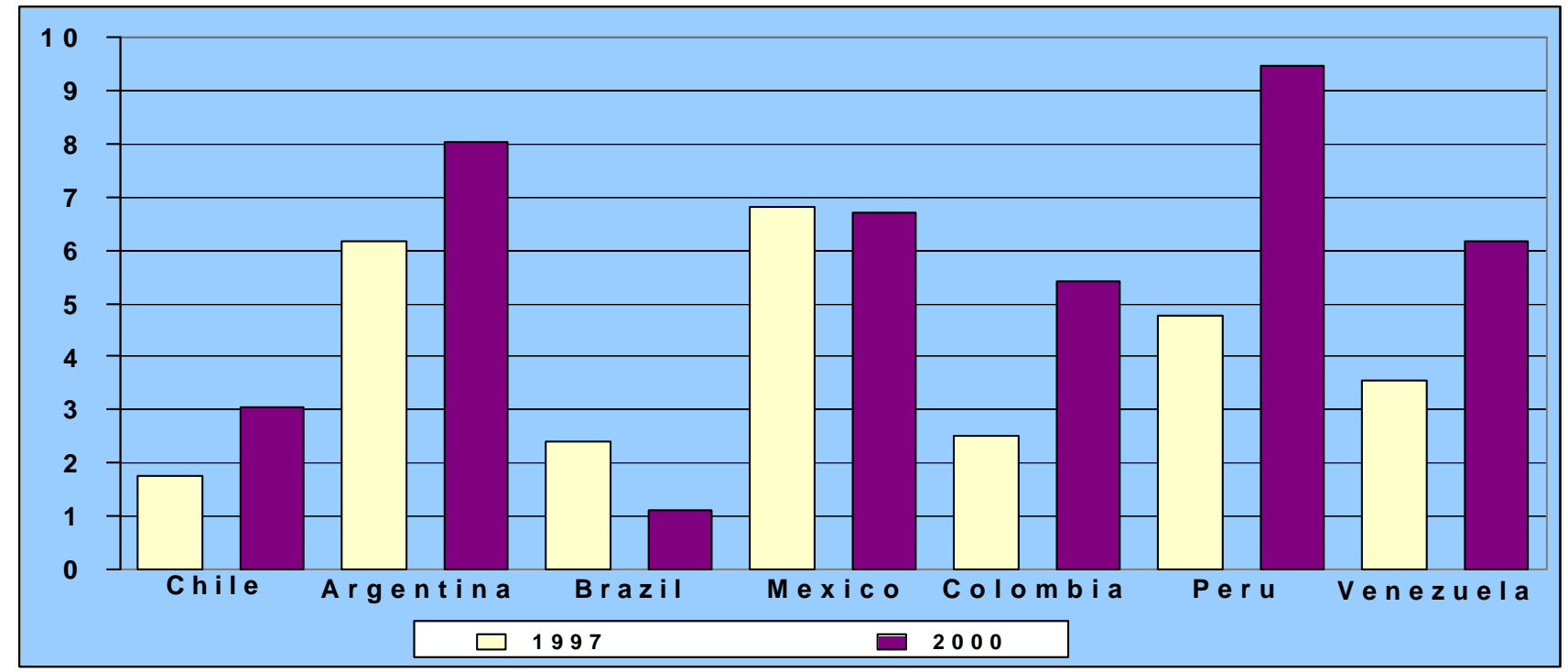

Source: Salomon Smith Barney (2000 and 2001a).

${ }^{46}$ See Stallings and Studart (2001). 
In Mexico, the scarcity of demand, specially during the 1995 recession, and possibly also the stricter standards imposed on banks' balances by tightening capital regulations and provisioning of non-performing loans, might explain some of the reduction in the supply of bank credit to the private sector in the years 1997 and 2000, but also the sharp increase in credit to the private sector offered by non-bank financial institutions, which are not subject to such strict regulation standards (graph 27).

G27: Mexico: Credit to the private sector (in billion pesos)

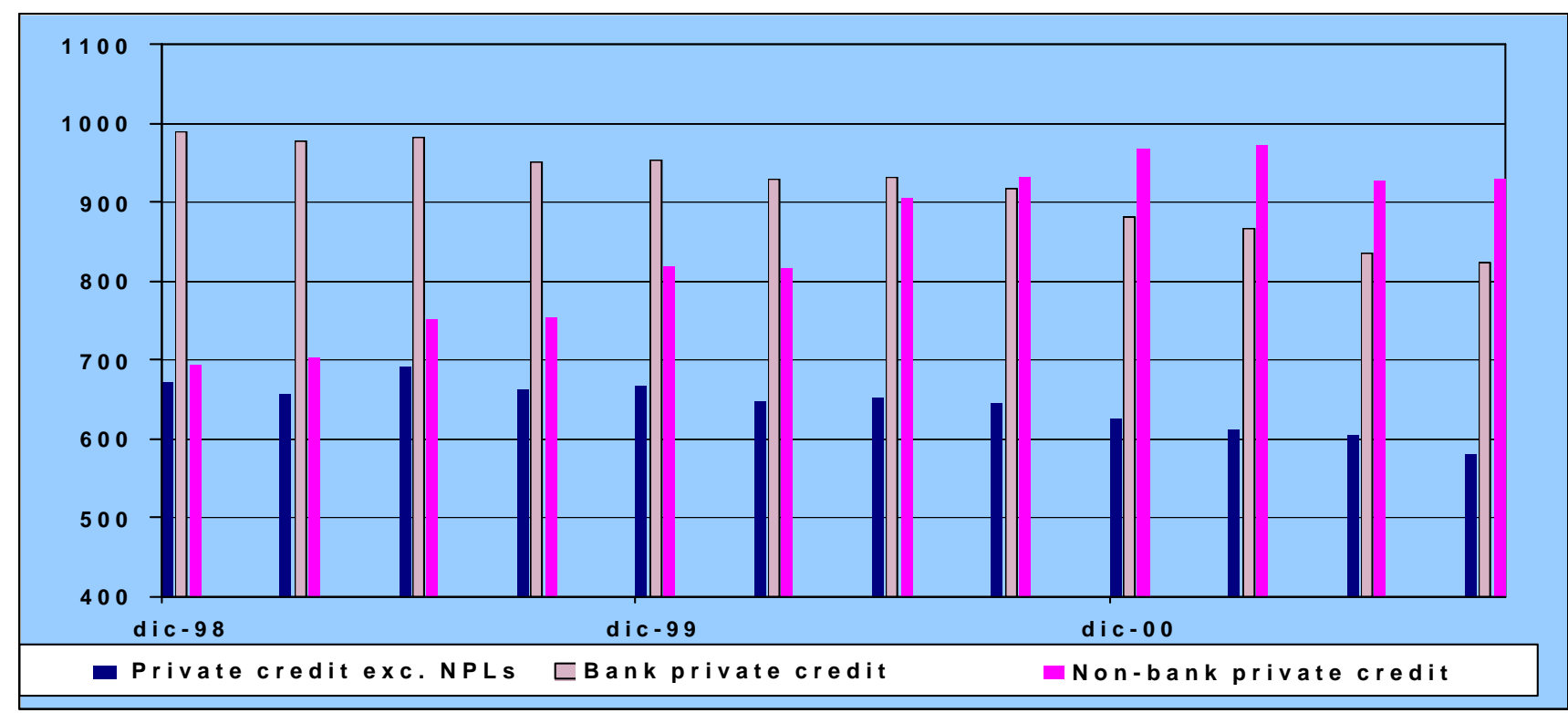

Source: Comisión Nacional Bancaria y de Valores (2002).

Note: Bank credit is total bank credit to the private sector including NPL and restructured loans. Non-bank credit includes private credit provided by a wide range of non-bank financial and non-financial institutions such as insurance companies, credit unions, leasing and factoring companies, and credit-card credit as well as non-domestic bank financing. Credit excluding NPLs (called "Crédito Vigente") is a proxy for "fresh credit".

Another possible explanation, related to the previous one, is the increase in nonperforming loans in several countries. A similar situation can be found in Argentina and Peru. In Brazil however, the low, or at least, decreasing volume of non-performing loans, and the broadly well capitalized and profitable banking system seems to point at other causes as explanation of the low availability of credit.

In addition, there appears to be crowding out from the public sector, particularly in the countries which have accumulated large public deficits overtime and whose debt is being financed domestically to a large extent. This seems to be the case in Cluster 2 (graph 28), also the one suffering from the lowest private credit relative to its financial depth. In contrast, Cluster 1 - the only group with a large amount of private credit - shows a much smaller and decreasing share of credit to the public sector. Clusters 3 and 4 present somewhat more inconclusive evidence, as both credit to the public and to the private sector are small. 
G28 Bank credit to the public sector in Latin America (as percentage of GDP)

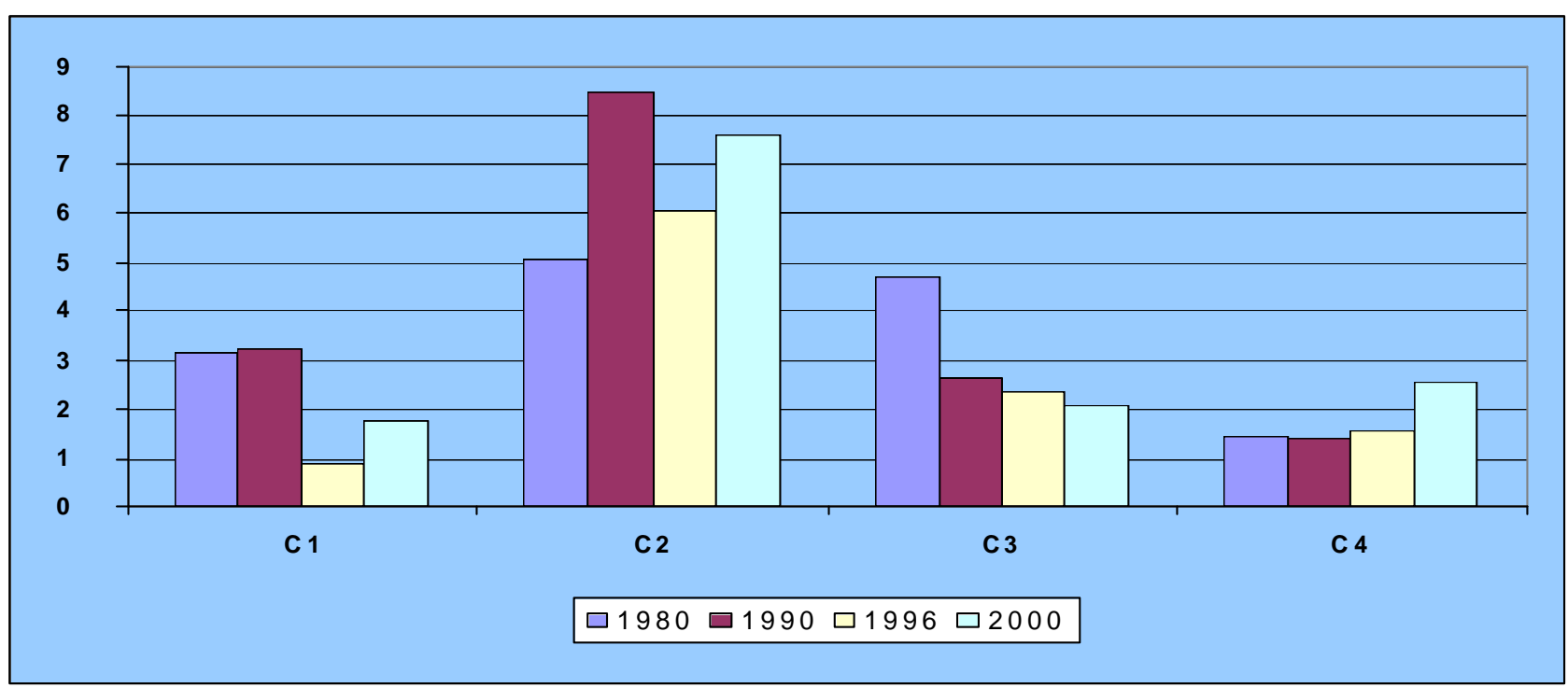

Source: Beck et al. (1999) and IFS (2001).

High real interest rates are an important factor limiting the demand for private credit. Graph 29 depicts very high real interest rates except in Cluster 4, and no conclusive evidence of a downward trend. This is a worrying feature as it shows that, despite over a decade of largely successful anti-inflationary policies in most countries, markets continue to demand a premium that is imposing a burden on corporate profitability.

G29 Real lending rates in Latin America

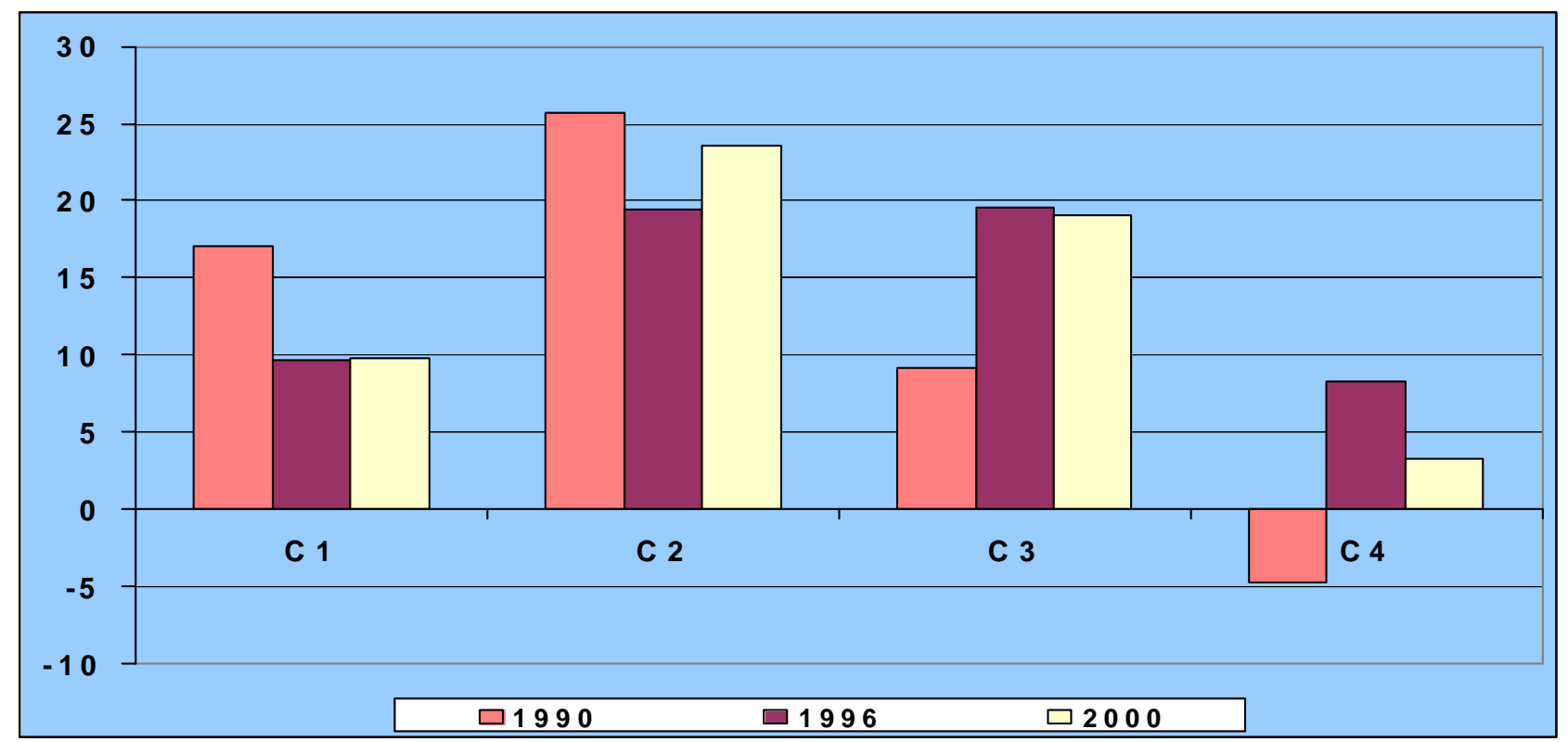

Source: IFS (2001).

Note: Calculated as the difference between nominal three-month lending rates minus inflation on the same period.

Real lending rates are particularly high in Cluster 2, coinciding with the largest share of public credit of all groups. Although a more in-depth analysis would be needed to reach a 
conclusion, it would seem as if countries in this cluster -or at least several of them ${ }^{47}$ - had conducted lax fiscal policies, contributing to the crowding out, and probably tight monetary policies to achieve stabilization, a policy-mix which eventually led to very high real interest rates.

Although bank credit is the most substantial source of financing for the private sector in Latin America, being a bank-based financial system, it is important to note that it is not the only one. As previously shown for Mexico, non-bank financial intermediaries are important for private financing in several countries. Stock market and private bond issuance are another source, particularly in the most financially developed countries, such as Chile, and also in Brazil. This includes the issuance in the domestic stock and bond markets but also abroad, either by means of American Depositary Receipts (ADRs) as concerns stocks, or through the issuance of bonds in the international markets (this will be tackled in more detail below). Another source of private financing is enterprises' direct financing from foreign banks. Some foreign banks - interested only in providing financing either to multinational firms or to the largest, most creditworthy, domestic firms in a given country usually prefer to use their off-shore offices, or even resort to direct lending from the parent company, rather than opening a bank subsidiary. This channel is now relatively less important, except in Chile, because of the increase in foreign ownership in local banking systems, which allows enterprises to finance themselves at a comparable, or even lower cost, domestically. As graph 30 shows, direct financing to Latin American enterprises from foreign banks was well below $10 \%$ of GDP, on average, in 2001, Chile being among the highest, followed by Costa Rica.

G30 External loans to non-financial enterprises in selected Latin American countries.

(as percentage of GDP)

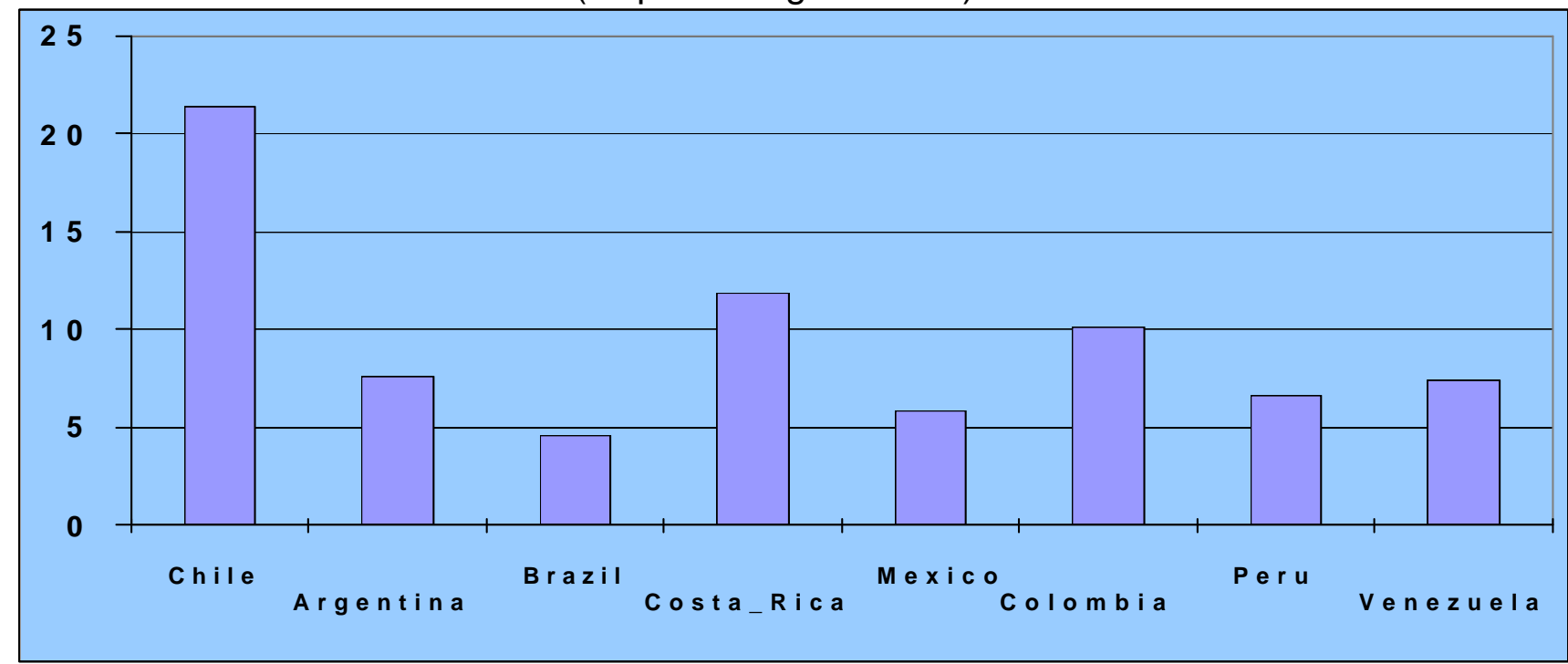

Data for 2001.

Source: BIS (2001).

Note: Total outstanding in the last quarter of 2000

${ }^{47}$ This is probably much less so for Mexico than for other countries. 


\subsubsection{Bank ownership}

In fact, (over the last two decades), foreign participation has been on a clear upward trend in terms of assets, soaring from an almost negligible share in 1980, to average levels close to $30 \%$ in 2000 (graph 31). It is remarkable that foreign bank participation was much larger in Cluster 1 already in $1990^{48}$. The countries in Cluster 2 started to see foreign ownership rise from 1990 onwards, as a consequence of their financial liberalization processes. They suffered banking crises in some instances, and the share of foreign participation grew faster than in any other cluster ${ }^{49}$.

It is also interesting to note how foreign bank participation has increased at the expense of government participation in the financial sector. Government participation used to be substantial in Cluster 2 (about 50\% of total assets in 1990), partly because of past financial crises, but it was drastically reduced in the second half of the 1990s. It is also noticeable that the most financially developed countries (Cluster 1 ), have never had significant government participation, which supports the findings of the economic literature. All in all, the fast increase in foreign participation may be considered a consequence of the region's stop-and go-liberalization processes, with the ensuing banking crises in some countries, and the large scale privatization processes which followed. The successful stabilization and the introduction of structural reforms were also key in this regard, together with external factors, such as the quest for new markets, as a consequence of the heightened competition in more mature financial markets.

G31 Bank ownership in Latin America (as percentage of total)

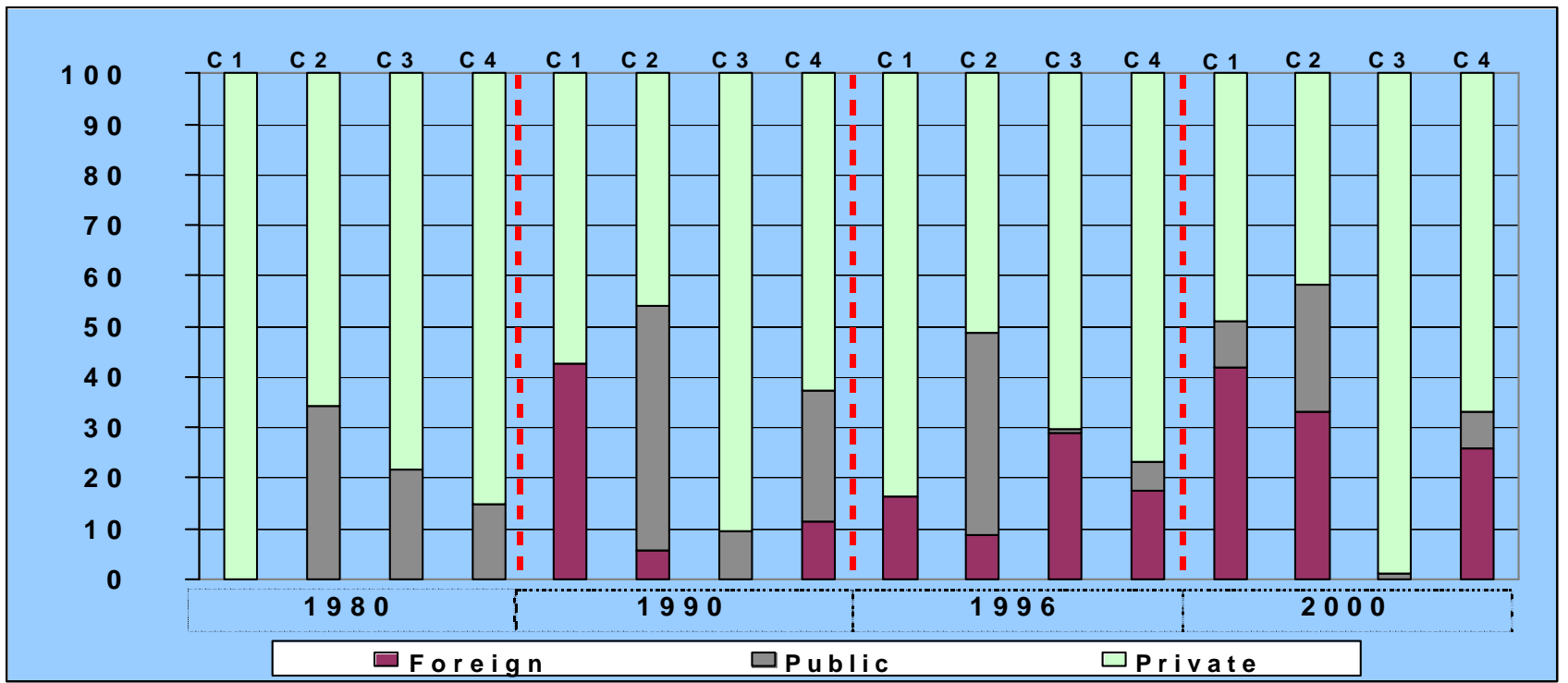

Source: Beck et al. (1999) and IFS (2001).

Note: A bank is defined as foreign if at least $50 \%$ of the equity is owned by foreigners. A bank is defined as public if at least $50 \%$ of the equity is held by the government or a public institution.

\footnotetext{
${ }^{48}$ Note that Panama explains a good part of this.

${ }^{49}$ It should be noted that the last wave of large privatisations in Mexico and Brazil (both in Cluster 2) do not appear in the graph.
} 


\subsubsection{Bank concentration}

Concentration has generally fallen in the region and in some cases quite abruptly (graph 32) until 2000, although a reversed trend started to develop in some countries in 2000, and appears to have continued in 2001, particularly in Chile, as foreign institutions already present in the local banking systems and also some local entities undertook a number of banks' acquisitions ${ }^{50}$.

G32 Bank concentration in Latin America

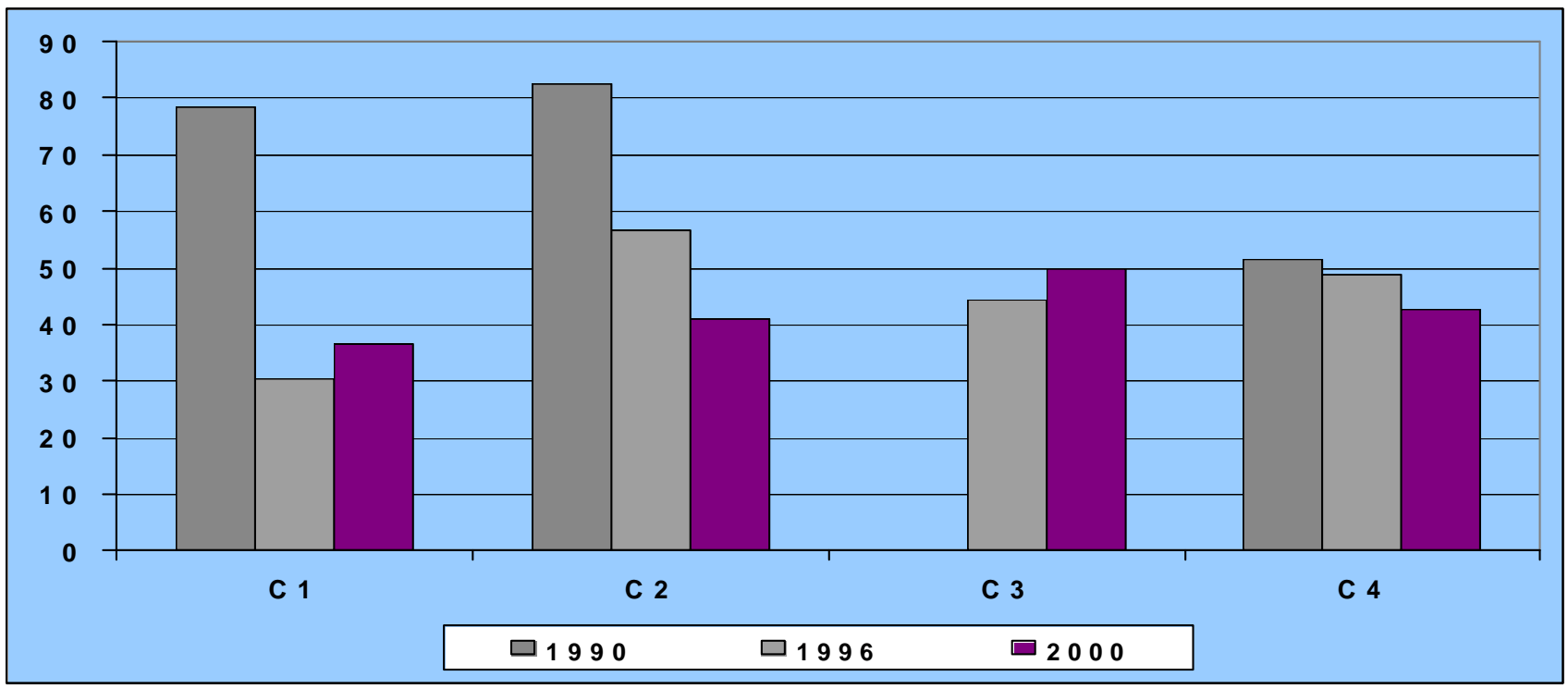

Source: Beck et al. (1999) and own calculations.

Note: Concentration is defined as the ratio of the three largest banks' assets to total banking sector.

Concentration was high in the most financially developed groups at the beginning of the 1990s, reaching $80 \%$ of total banking sector assets in the three largest banks. It then shrank substantially, to around $35-40 \%$ of total banking sector assets in 2000 . Concentration has actually risen over time in the lowest income, Cluster namely Cluster 3 , although it does not exceed $50 \%$, which is still a moderate percentage for international standards. As previously mentioned for the regional comparison, it is difficult to draw conclusions on the relation between the increase in foreign participation and bank concentration. On the one hand, a further increase in foreign participation is part of the reason why concentration in Chile has increased in 2001. On the other hand, the group of countries with the highest concentration (C3) is also the one with virtually no foreign banks.

\footnotetext{
${ }^{50}$ Stallings and Studart (2001) show a somewhat different trend based on banks' deposits and not on assets, drawing from data in Mathieson and Schinasi (2001).
} 


\subsubsection{Institutional factors: the central bank and bank supervision and regulation}

The functioning of Latin American central banks has substantially improved in the 1990s, after the experiences related to the debt crisis. Central bank independence has increased in most countries ${ }^{51}$ and central bank objectives have been defined more narrowly, focusing on price stability as single or, at least, main objective ${ }^{52}$.

Apart from the conduct of monetary policy, central banks have other functions more directly related with the functioning of the banking system. A crucial one is the operation and/or oversight of the payment and settlement system. The central bank involvement in this field is relatively high in some countries of the region, particularly in Brazil and Peru, while it is other very limited in Argentina, Chile and Trinidad and Tobago (see the height of the columns on graph 33). Another aspect is bank regulation and supervision, although this is generally conducted outside the central bank in many Latin American countries (see color of the bars in graph 33).

G33 Institutional factors in selected Latin American countries

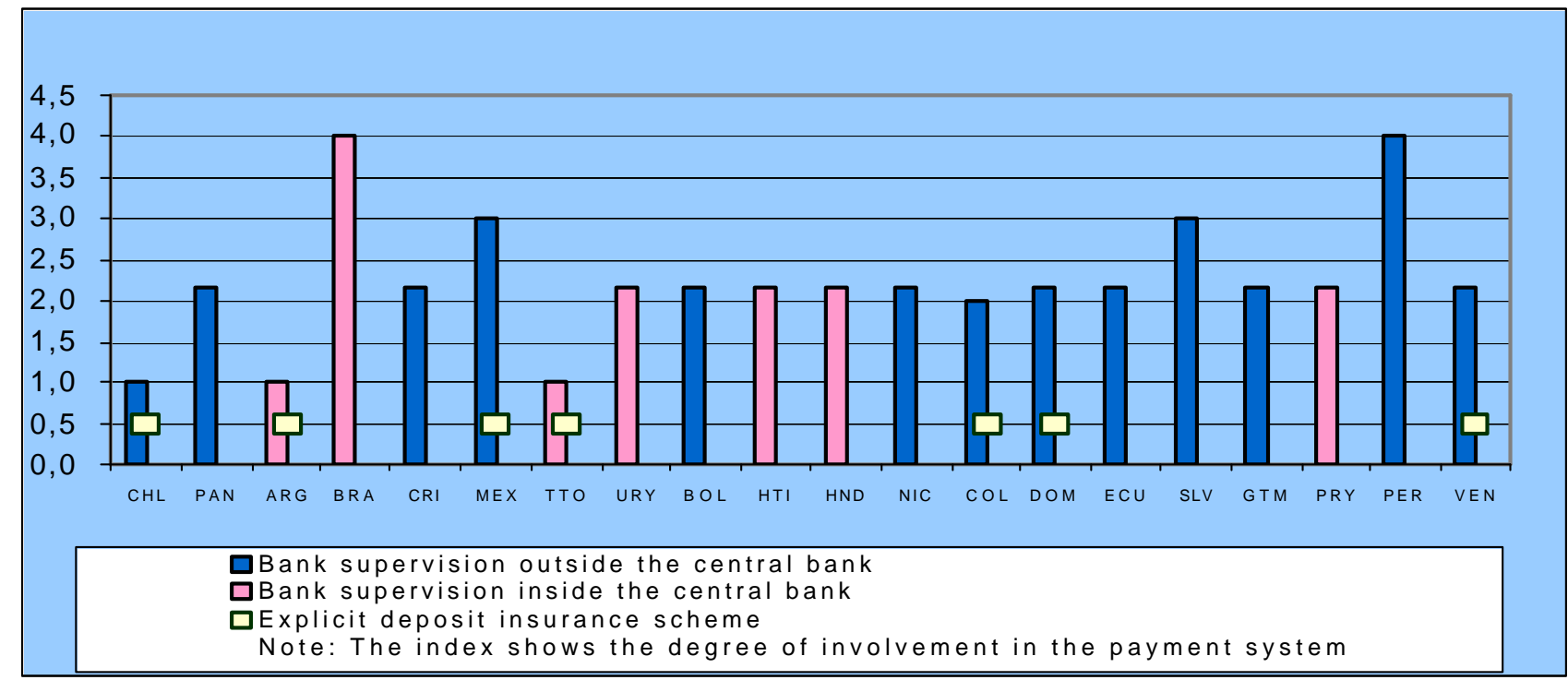

Source: Fry et al. (1999), Tuya and Zamalloa (1994) and Demirgürç-Kunt and Sobaci (2000)

Note: The higher the bar the more involved is the central bank in the operation and oversight of the payment system.

Another important institutional feature is the existence of a deposit insurance scheme (DIS). More and more countries are introducing explicit and limited DIS, to avoid implicit and thus non transparent - arrangements, as recommended by the literature. Explicit and limited DIS exist in Chile, Argentina, Mexico, Trinidad and Tobago, Colombia, Dominican Republic and Venezuela (see square in graph 33 , above).

\footnotetext{
${ }^{51}$ Cukierman, Webb and Neyapti (1992).

${ }^{52}$ Aguirre, Junguito and Miller (1997) and Aguirre (2000).
} 
Banking regulation and supervision has improved considerably particularly after the banking crises of the first half of the $1990 \mathrm{~s}^{53}$. This includes the adoption of Basel criteria for capital adequacy and the strengthening of the independence of bank supervisors, as well as the creation of a culture of good corporate governance and informative financial disclosure. The improvement of bank supervision, as well as the arrival of retail foreign banks, have contributed to sounder bank management practices and increased consideration for risk. The effectiveness of these measures, however, critically depends on the rule of law, which is still weak in some countries.

Although it is extremely difficult to compare the quality of bank supervision among countries, for illustration purposes an attempt of such exercise is reflected in graph 34, on the basis of a recent survey by the World Bank (Barth, Caprio and Levine. 2001). Despite the shortcomings that the survey may have, including that it does not show the current picture but rather that of the end of the $1990 \mathrm{~s}^{54}$, it is interesting to note that those countries more financially developed (Cluster 1 ) are also those with stricter capital requirements and with more independent supervision. Evidence for the rest of the clusters is somewhat inconclusive ${ }^{55}$.

G34 The quality of bank regulation and supervision in Latin America

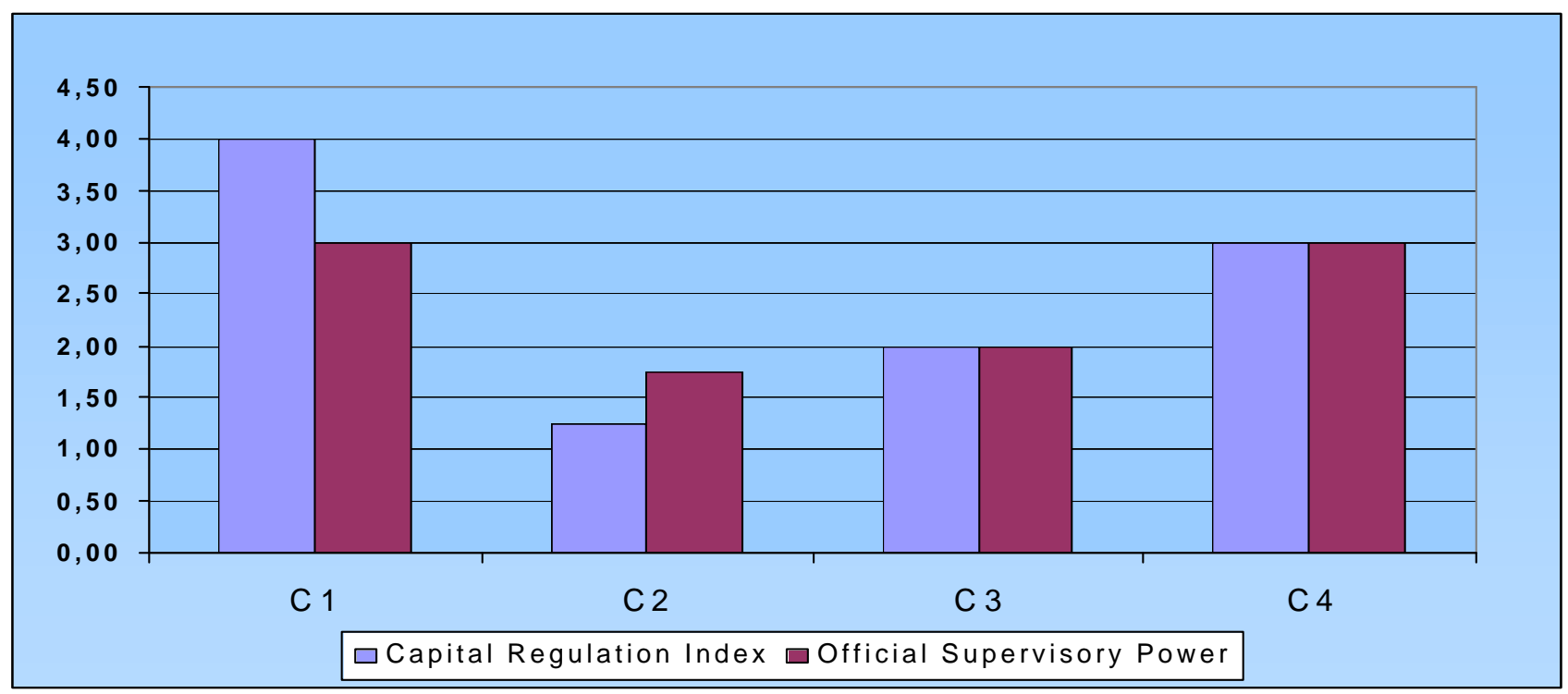

Source: Own calculations based on a World Bank questionnaire addressed to national regulation and supervisory authorities worldwide conducted by Barth, Caprio and Levine (2001).

Note: The capital regulation index measures the degree of capital stringency in a country, both at the regulatory and the implementation levels. The official supervisory power quantifies whether the supervisory authorities can take specific actions to prevent and correct problems.

\footnotetext{
${ }^{53}$ García-Herrero (1997).

54 This is particularly important for countries such as Mexico, but also for Brazil and Argentina, which have improved their regulation and supervision standards in the last few years.

${ }^{55}$ It should be noted that these calculations are subject to the aggregation methodology used. Stallings and Studart's (2001) make their own calculations, based on the same source, and obtain a somewhat different ranking.
} 


\subsection{Capital markets}

In order to analyze the current situation of Latin American capital markets in terms of size and efficiency, it is useful to look backwards. The development of capital markets in Latin America can be traced to the oil-related sudden inflows of funds following the 1973 oil crisis $^{56}$. A significant share of the excess liquidity in the world flew to Latin America, particularly to those countries which had just liberalized their financials systems, mainly in the form of syndicated loans. Subsequent developments led to the crisis that took place in the early 1980s (which burst in Mexico and then spread to a large number of countries) and to the implementation of the Brady Plan. In that context, the Brady debt restructuring, together with the structural reforms undertaken in many countries, contributed to securitizing a good part of the external liabilities of the region ${ }^{57}$.

Since then, increasing amounts of new bonds have been issued, part of which have replace Brady bonds with other instruments. Today, bond markets are relatively wellrooted in a number of countries of the region, and others are following the same path.

In the process just summarized, foreign investors played a significant role, partly because of the structural deficit of savings prevailing in the region. This was particularly the case in the early stages of the bond market development, in the first half of the 1990s, when large capital inflows were concentrated in portfolio investment in fixed income. The following sections discuss the size and efficiency of Latin American bond and stock markets.

\subsubsection{Domestic bond markets}

As previously shown, the size of domestic bond markets in Latin America is still small compared to other emerging regions. Along the past decade, issuance and secondary market conditions in Latin American bond markets, both domestic and external, remained very much subject to domestic macroeconomic volatility but also to shock in global financial markets. Notwithstanding these difficulties, foreign-currency-denominated bond issuance, which had been almost non-existent before 1990, increased steadily. The amount outstanding of domestic bonds reached 500 billion US $\$$ at the end 1998, and then started to fall although maintaining relatively high levels: 400 billion US $\$$ at end-2001 (graph 35). In the following years, Latin American bond issuers also started to diversify among currencies, increasing the share of the euro-denominated issuance to $25 \%$ of total in 2000 .

\footnotetext{
${ }^{56}$ See Buckley (1999) for a detailed historical account of the Latin American debt market.

57 See Bustillo and Velloso (2000) and Salomon Smith Barney (2000) for a description of Brady bonds. Alberola and González Mota (2001) discussed the links between market structure and volatility.
} 
G35 Latin American Domestic Bonds: Amounts outstanding

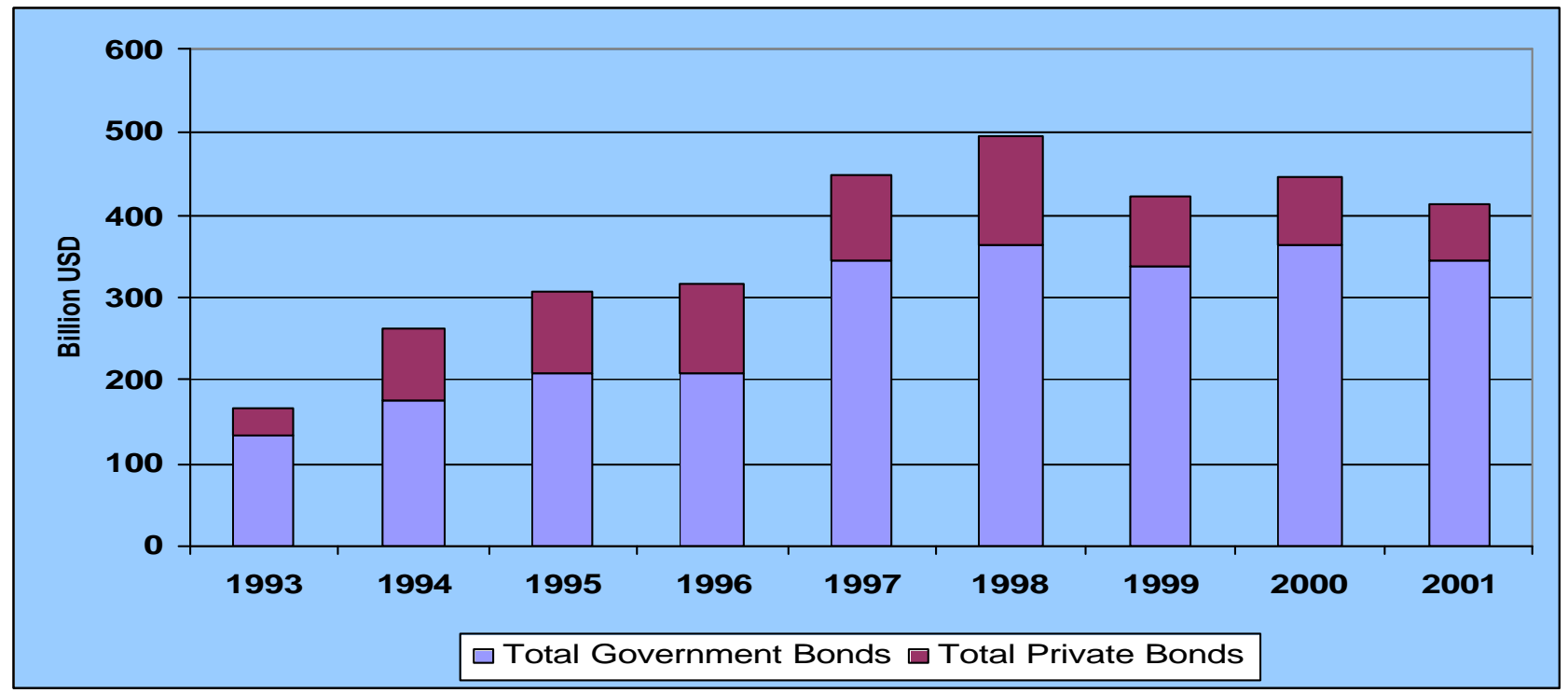

Source: BIS (2001).

With the reduction in portfolio flows to the region after the 1998 Russian default and the continuous need to finance fiscal deficits, domestic bond markets grew rapidly in the second half of the 1990s. By the end of 2000 , on average, something more than $50 \%$ of the existing debt was domestic, although this figure is very much influenced by Brazil's large domestic bond market. The bulk of the domestic bond market is government paper, in Brazil and in the rest of the Latin American countries, being Chile the only exception.

G36 Outstanding government bonds in selected Latin American countries: domestic and external

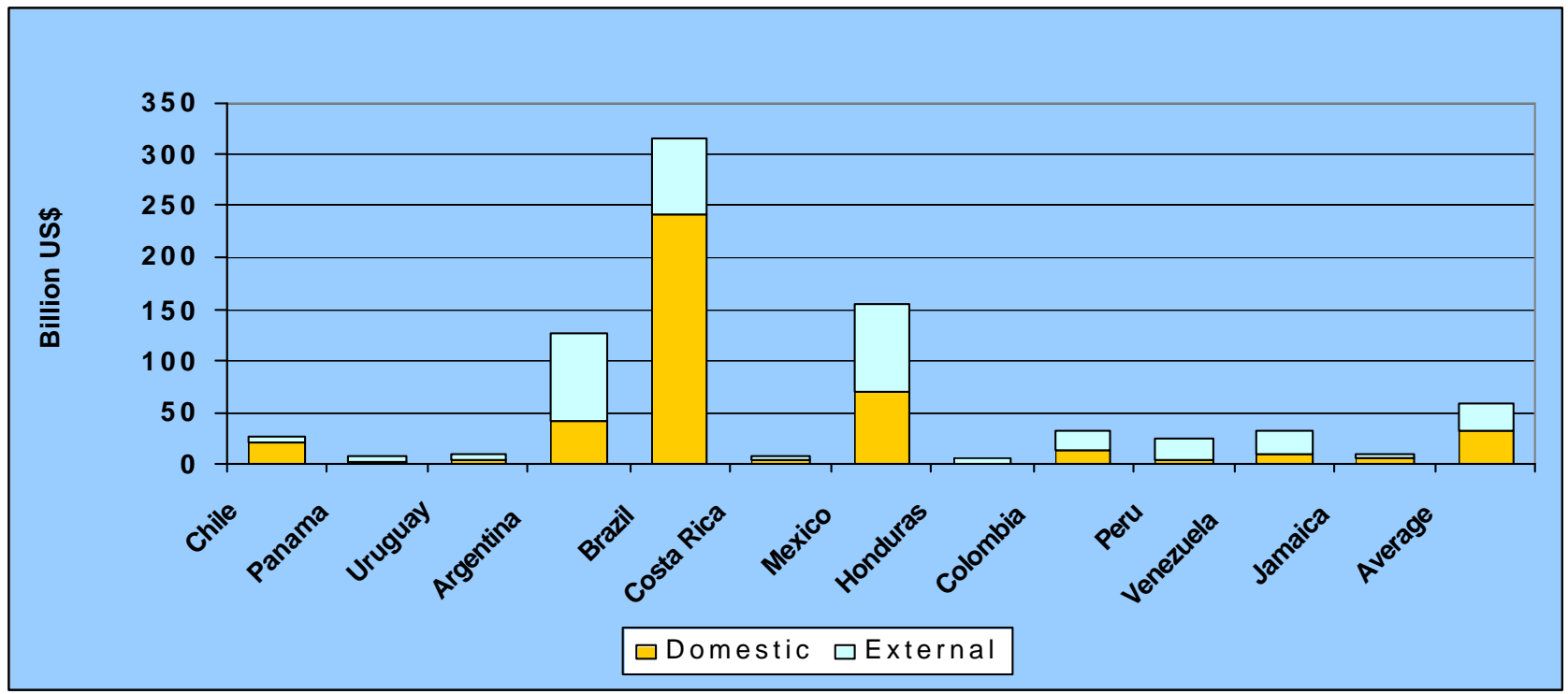

Data for 2000.

Source: World Bank (2001a). 
Given the relatively small number of countries with sizeable capital markets relative to their banking systems, the graphs in this section show countries and not clusters, although countries are still ordered in terms of the clusters found in Section 3, from most to least developed in terms of financial depth.

An interesting question is the extent to which the external debt markets have contributed to - or hindered - the development of domestic debt markets. While a conclusive answer to this question would require a more detailed analysis, a first look at the evidence shows more complementary than substitutability between both markets. The cases of Chile and Brazil and, to a lesser extent, Mexico and Argentina, show that domestic debt markets can cover a good part of the financing needs of the government and the corporate sectors (graph 36), even when external markets are open for new issuance. In these cases, the inflow of external saving appears to have helped local markets to take off once macroeconomic conditions and the institutional setting improved.

There are a number of reasons why countries in the region have incentives to develop domestic markets ${ }^{58}$, such as the more efficient use of local savings, the increased opportunities for small and medium sized firms, and the smaller dependence on foreign capital flows. Building local financial markets also requires considerable legal and technological infrastructures and investment in human capital, which in turn should help strengthen other areas of the domestic financial system. The evolution of the cost of raising capital in the domestic and the external bond market varies substantially among countries (graph 37) and overtime, depending on the degree of macroeconomic, or financial, volatility. In any event, the difference in the cost of external and domestic financing has narrowed in most countries, even when taking into account the exchange rate, which is a major component of any borrowing decision.

${ }^{58}$ See Harwood (2000), Mathieson and Schianasi (2001), and Guiso, Sapienza and Zingales (2002). 
G37 Domestic versus external interest rates for Latin American countries
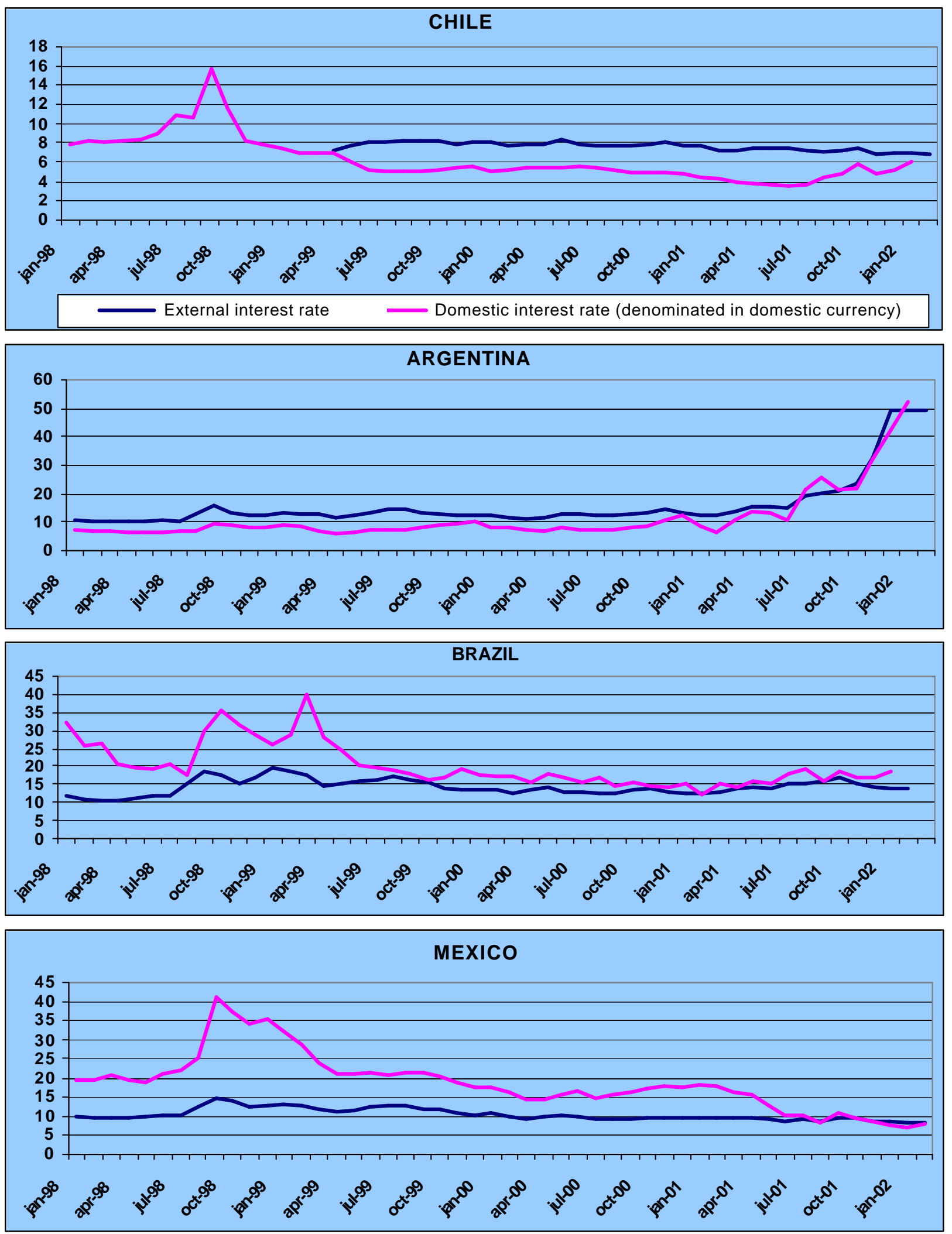

Source: Bloomberg.

Note: The external interest rate is defined as the yield on the national component of the EMBI (emerging market bonds index). In the case of Chile the external rate is the yield on the Global 09 bond. The domestic interest rate is defined as the benchmark 3-month deposit or interbank rate. 
G37 Domestic versus external interest rates in selected Latin American countries


Source: Bloomberg.

Note: The external interest rate is defined as the yield on the national component of the EMBI (emerging market bonds index). In the case of Chile the external rate is the yield on the Global 09 bond. The domestic interest rate is defined as the benchmark 3-month deposit or interbank rate. In the case of Peru, the 3-month deposit rate in soles is hardly representative. 
As regards efficiency in the bond market, turnover in the secondary bond markets has increased in several countries although it is considerably higher in the external bond market, except for Mexico (graph 38). Turnover is very much influenced by the existence of a benchmark status and the availability of liquid derivatives contracts to hedge positions, as is the case in Brazil.

G38 Turnover in the selected Latin American government bond markets

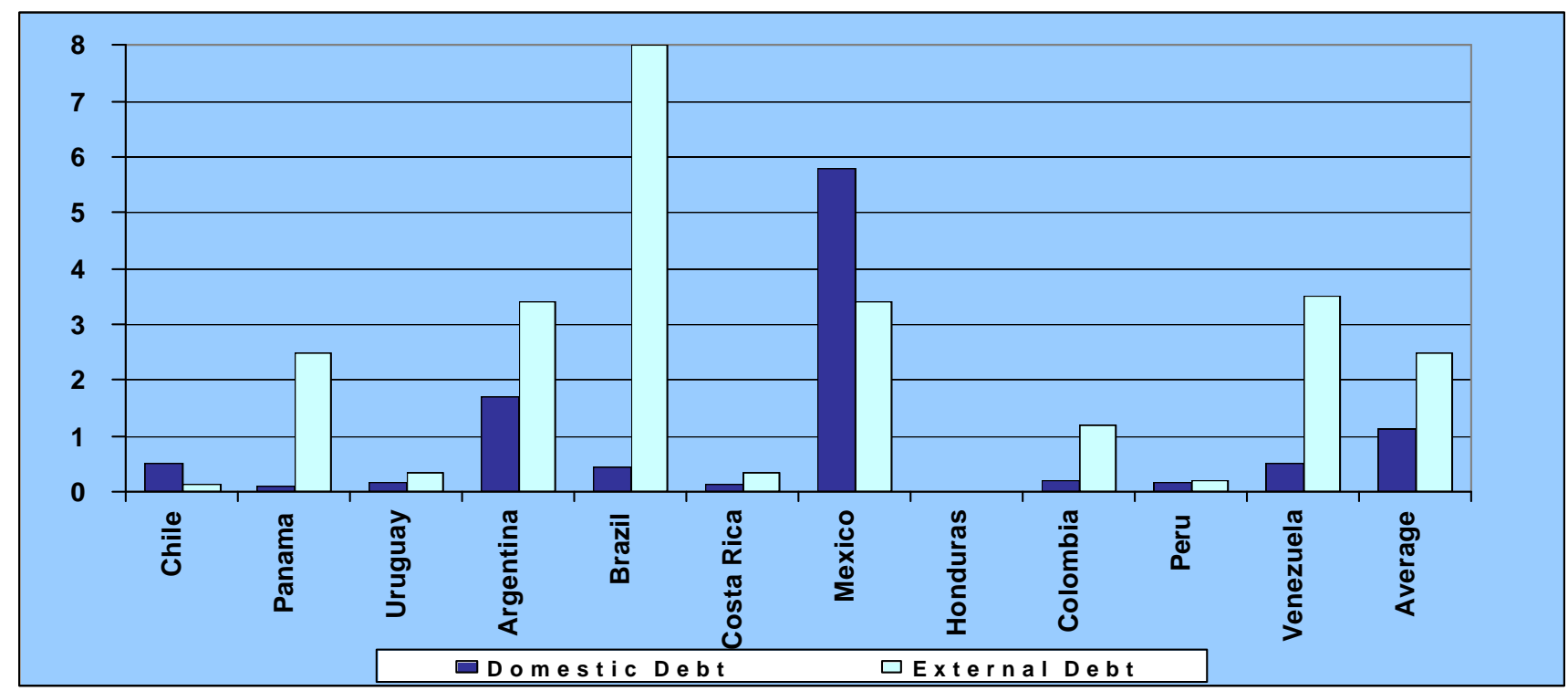

Data for 2000.

Source: World Bank (2001a).

Note: Value traded divided by total outstanding.

As regards operational efficiency, de-materialization of debt has been completed in several countries, which together with other ongoing improvements in infrastructure, clearing and settlement are setting the basis for more efficient markets. In addition, debt management has become more active in a number of countries, as indicated by the re-opening and buybacks of issues, both aimed at improving the liquidity of existing issues. Other reforms implemented in some cases include the introduction of primary dealers, and the increasing regularity of the issuance, which should improve the functioning of the primary and secondary markets.

The situation of domestic bond markets in Latin American countries- even if in a generally improving trend - is still very heterogeneous. Some markets remain vulnerable usually due to a short average maturity, or to the fact that a substantial share of debt is issued at variable interest rates or is denominated in foreign currency. As regards maturity, the situation for government debt improved for the region as a whole prior to the 1998 crisis although maturity fell again and more or less stabilized in recent years at 4,5 years, on average, (in 2001). Graph 39 shows that Panama, followed by Costa Rica, had the highest maturity in 2001. In the last two years Mexico has developed a rather successful strategy of lengthening maturities. 


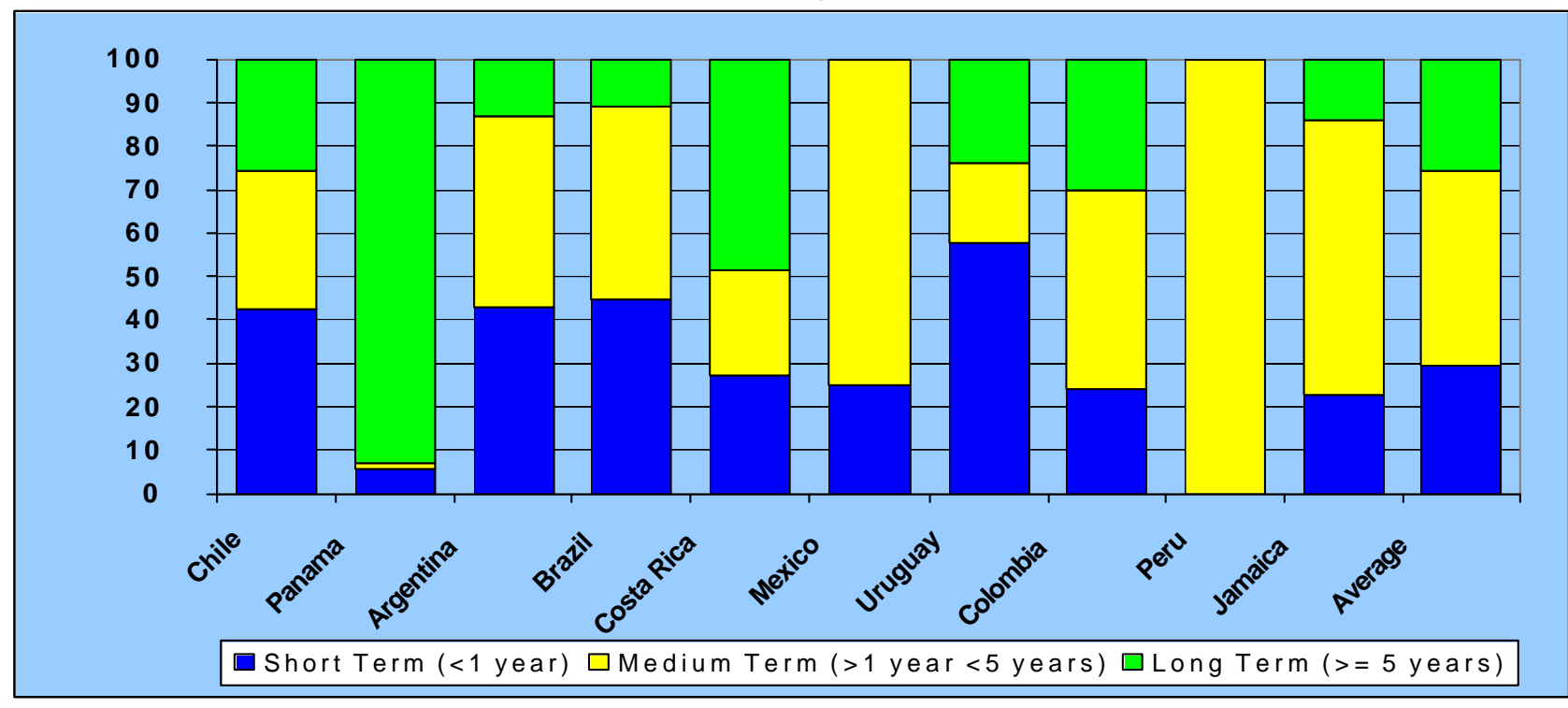

Data for 2000

Source: World Bank (2001a).

Note: Mexico has started to issue long term bonds but available data is not readily comparable with the one used for this graph.

As for the interest rate structure and the currency composition, graph 40 shows that, on average, over $40 \%$ of total domestic government bonds were issued at variable interest rate in 2001. Slightly more than one third were issued at fixed rate, and about $20 \%$ were indexed. Excluding Chile however, the latter component becomes much smaller. Panama and Argentina - the "super-fixers" of the group in terms of the exchange rate regime in 2001 - have significant percentages of fixed rate debt but all their debt was denominated in foreign currency in $2001^{59}$. This was also the case in Uruguay and Peru to a very large extent (graph 41). The transfer of risk from the interest rate to the exchange rate was clear in the case of Argentina. For the remaining countries, except Colombia, dependence on variable rates has remained significant, although debt is generally denominated in domestic currency, which tends to reduce vulnerability. A relatively good combination is that of Chile, with virtually all debt denominated in domestic currency and inflationindexed. There are, however, other caveats regarding indexed instruments, which need to be considered, such as the difficulty in reducing inflation expectations and the increase in debt service, when the currency depreciates. Another disadvantage of inflation-indexed debt is its illiquidity relative to fixed-rate securities. In this regard, Mexico has made substantial progress in the last few years in building a long-term, local currency and fixedrate government securities market.

\footnotetext{
59 This is obvious for Panama, being an officially dollarized economy. Argentina has abruptly reverted this trend with the pesification of government debt held domestically.
} 
G40 Interest rate structure of outstanding government bonds (as percentage of total)

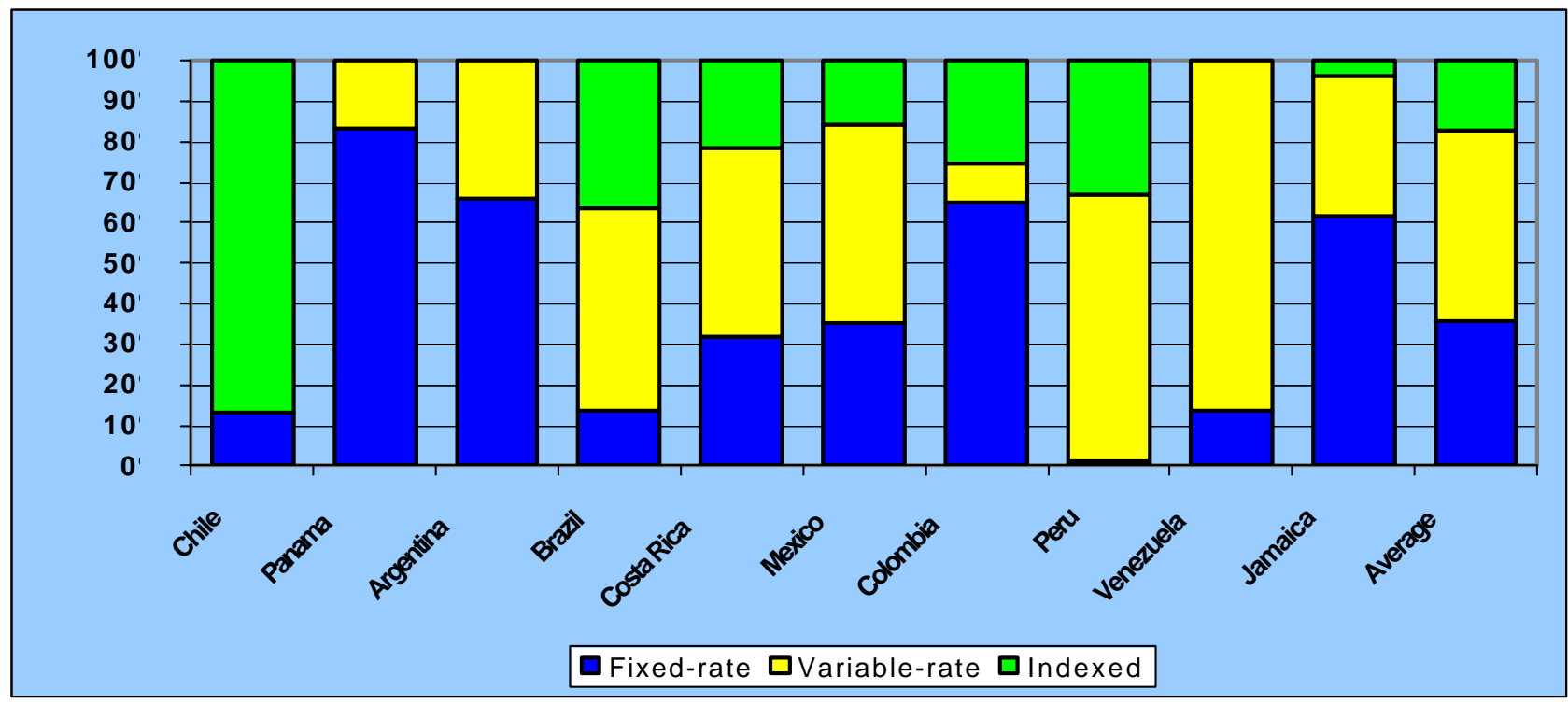

Data for 2000

Source: World Bank (2001a).

G41 Domestic government debt by currency of denomination (as percentage of total)

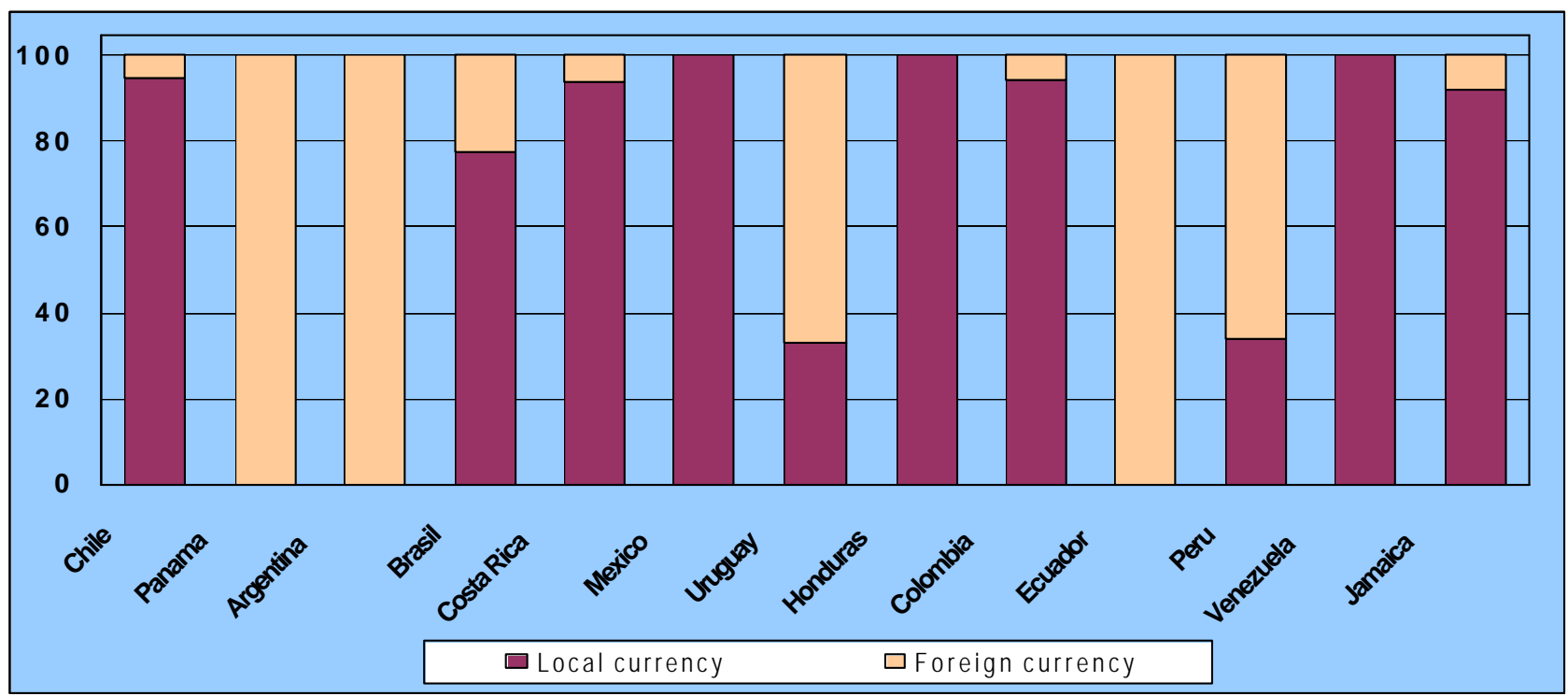

Data for 2000

Source: World Bank (2001a).

The holder structure of domestic government bonds is also different among countries with one exception: households and corporates still hold only a marginal part of the total amount outstanding. The share of institutional investors' holdings is also small, compared to international standards, in virtually all countries (Graph 42) except for Brazil, Chile and $\operatorname{Peru}^{60}$. Another peculiarity worth mentioning is the significant weight of the public sector in some countries such as Panama, Honduras and Colombia, which is generally due to large

\footnotetext{
${ }^{60}$ Note that the size of Peru's debt market is very small.
} 
holdings of government bonds by public banks. In sum, the current holder structure indicates a substantial potential for the development of institutional investment in the region, as well as of household and corporate sectors. Such development should be reached gradually as the markets become more mature, within a virtuous circle, that should materialize as far as countries approach potential growth and domestic saving rates increase.

G42 Holders of domestic government bonds outstanding (as percentage of total)

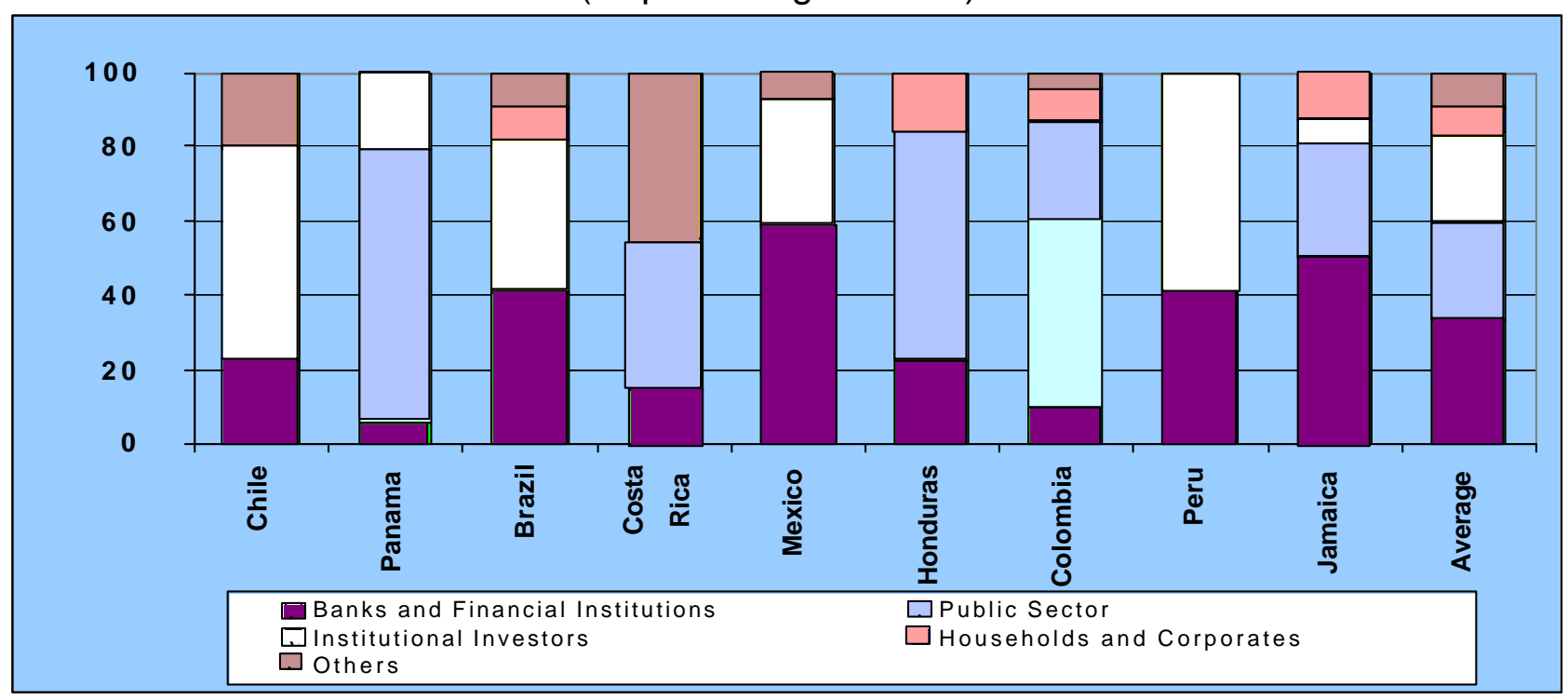

Data for 2000

Source: World Bank (2001a).

\subsubsection{Equity markets}

The overall development of Latin American equity markets is still rather limited. During the second half of the 1990s and the start of the present decade developments in the regional equity markets were significantly influenced by the wave of privatizations of several of the large corporations, a process which brought to the region huge amounts of foreign investment and thus demand for local equities. At a second stage, many of these same companies were acquired by foreign corporations and, as a consequence, trading in some of the stocks which had previously enjoyed a high turnover in the continent was discontinued. Hence, the overall impact of these acquisitions on the development of Latin American stock markets is not clear.

In addition, increased risk aversion for all emerging markets at the end of the 1990s impacted Latin American equities markets adversely. All in all, the size of local markets has stagnated in the last few years (graph 43) and remains low compared to emerging Asia $^{61}$.

\footnotetext{
${ }^{61}$ The comparison can be found in graph 12 .
} 
G43 Stock market capitalization in selected Latin American countries

(as percentage of GDP)

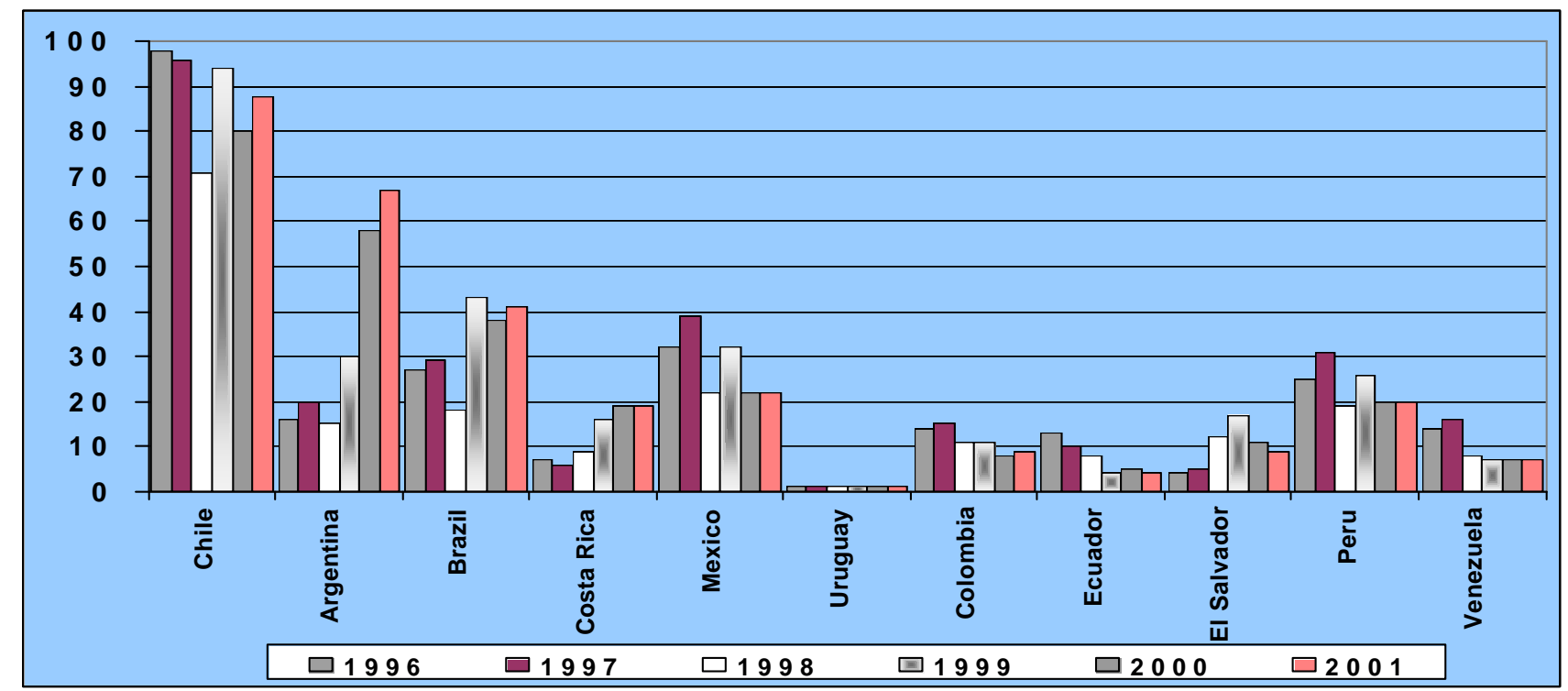

Source: Federación Iberoamericana de Bolsas de Valores (2000 and 2001).

The relation between efficiency and size in the stock market is not so clear cut as in the case of the banking system. Graph 44 shows much a smaller efficiency (measured as turnover) relative to size (measured as stock capitalization to GDP) for the most financially developed group, Cluster 1, while Cluster 2, much smaller in terms of size, appears as much more efficient.

The last few years have been characterized by a generalized, often very pronounced, reduction of turnover in many stock markets of the region. For instance turnover in Brazil, Mexico and Argentina roughly halved in the period 1997- 2000. Such decline was, to a certain extent, explained by a parallel increase of trading of Latin American equities in ADRs, mainly in the New York Stock Exchange, which multiplied by 5 between 1995 and $2000^{62}$. The reasons behind this development are closer access to large institutional investors and lower transaction costs notwithstanding more demanding disclosure requirements for ADR traded companies. Two cases worth mentioning are Chile and Argentina. The Chilean institutional and regulatory framework is well developed and experienced a very positive turnover trend during several years but was reversed in the late $1990 \mathrm{~s}^{63}$. The Argentinean stock exchange showed a very positive evolution regarding turnover in the period 95-97, to fall sharply thereafter. Both cases can be partially explained by the general negative evolution of the stock market worldwide, but also by the increasing trading in ADRs for the stocks of these countries' largest companies.

\footnotetext{
${ }^{62}$ Moel (2001) finds a positive impact of ADRs on overall liquidity of the stocks and also, indirectly, on the domestic accounting standards of the relevant local markets, an effect which takes place through the impact of external practices. He also finds a sharp fall in the liquidity of the relevant stocks in local markets.

${ }^{63}$ See Fernandez-Arias (2000) and Hausmann (2000).
} 
G44 Stock market capitalization and turnover in Latin America

(as percentage of GDP)

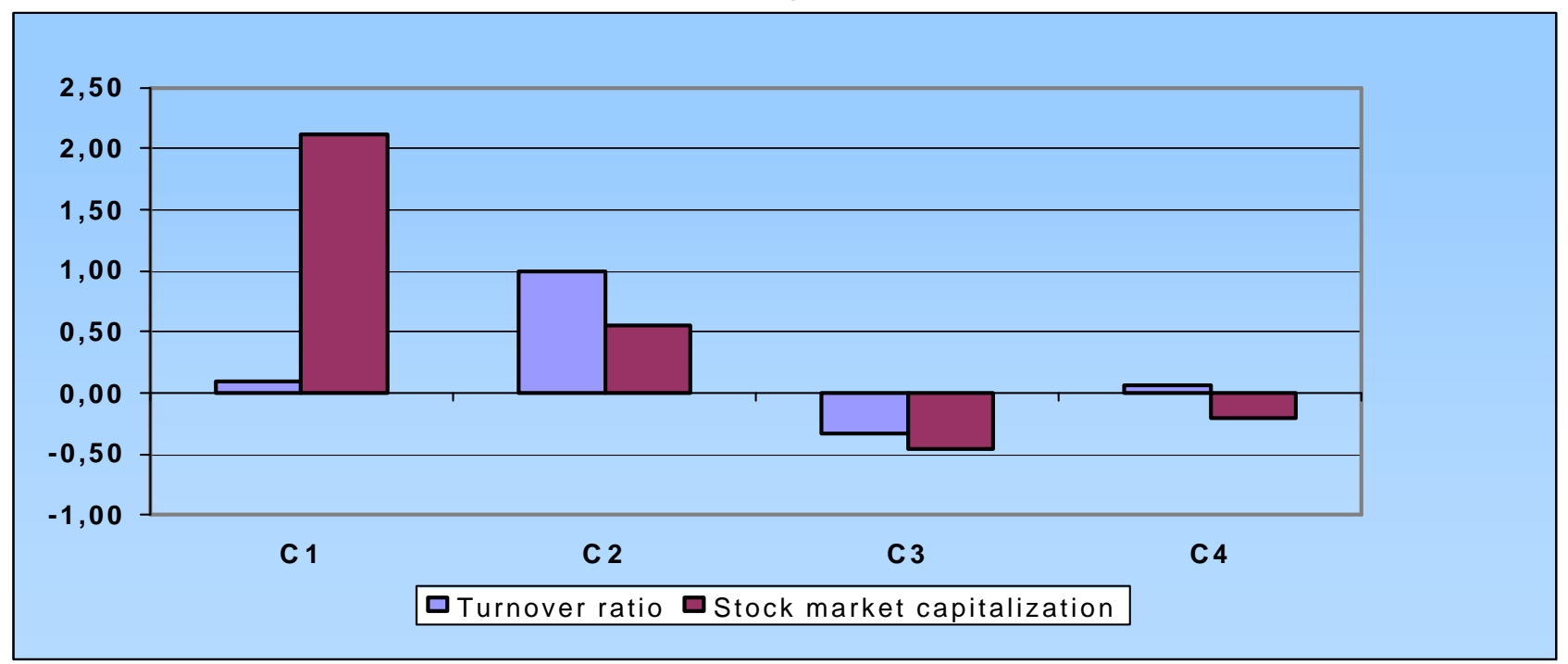

Data for 2000

Source: World Bank (2001c).

Note: The turnover gives the value of the stock transactions relative to the size of the market. All data have been normalized.

In light of the ongoing reduction in market capitalization and liquidity in most domestic stock markets, countries have strengthened their regulatory and institutional frameworks so as to equip national financial systems with efficient and competitive equity markets. The cases of Mexico and Brazil are good examples of this.

Another interesting development is the existence of relatively new initiatives, in line with what is happening in the rest of the world, to create sub-regional alliances via cross-listing agreements (the best example is in Peru and Ecuador) or infrastructure cooperation ${ }^{64}$. As the European experience shows, there is a lot to be gained from joint initiatives in terms of operational efficiency and also potentially in terms of market efficiency, to the extent that such initiatives help to reach the critical size needed to ensure appropriate liquidity.

\subsubsection{Institutional investment}

As has often been argued, one of the main problems for the development of Latin American financial markets is the structural deficit of domestic savings. This makes countries critically dependent upon foreign saving and limits the demand for financial products domestically. The role that local institutional investors can play in the consolidation of sizeable and efficient local financial markets can hardly be exaggerated, as the experience of other areas of the world shows.

\footnotetext{
${ }^{64}$ It is also worth mentioning an ongoing project to integrate debt markets and payment systems in Central America, led by the Central American Monetary Council.
} 
One of the main steps that many Latin American countries have taken to maximize the efficient use of domestic savings in the capital markets is the development of local institutional asset management through pension reform initiatives. The importance of this development lies in the introduction of global best practices, the good functioning of local capital markets and the provision of a stable source of funds for longer dated assets. Such a development should also limit the negative effect of excessive volatility of foreign funds ${ }^{65}$.

According to available data (graph 45), pension funds in Latin America managed over 175 billion dollars at the end of 2000 . Almost $100 \%$ of these assets were invested in local securities, mostly bonds, thereby underpinning the growth of this market. This, however, may imply potential risks if domestic issuers face illiquidity or solvency problems. In Chile, pension funds have been in place for quite a few years. Other countries started later but are moving fast, particularly Bolivia. While Chile is the only country having reached a significant size, the potential for growth is large for many countries.

G45 Pension fund assets under management (as percentage of GDP)

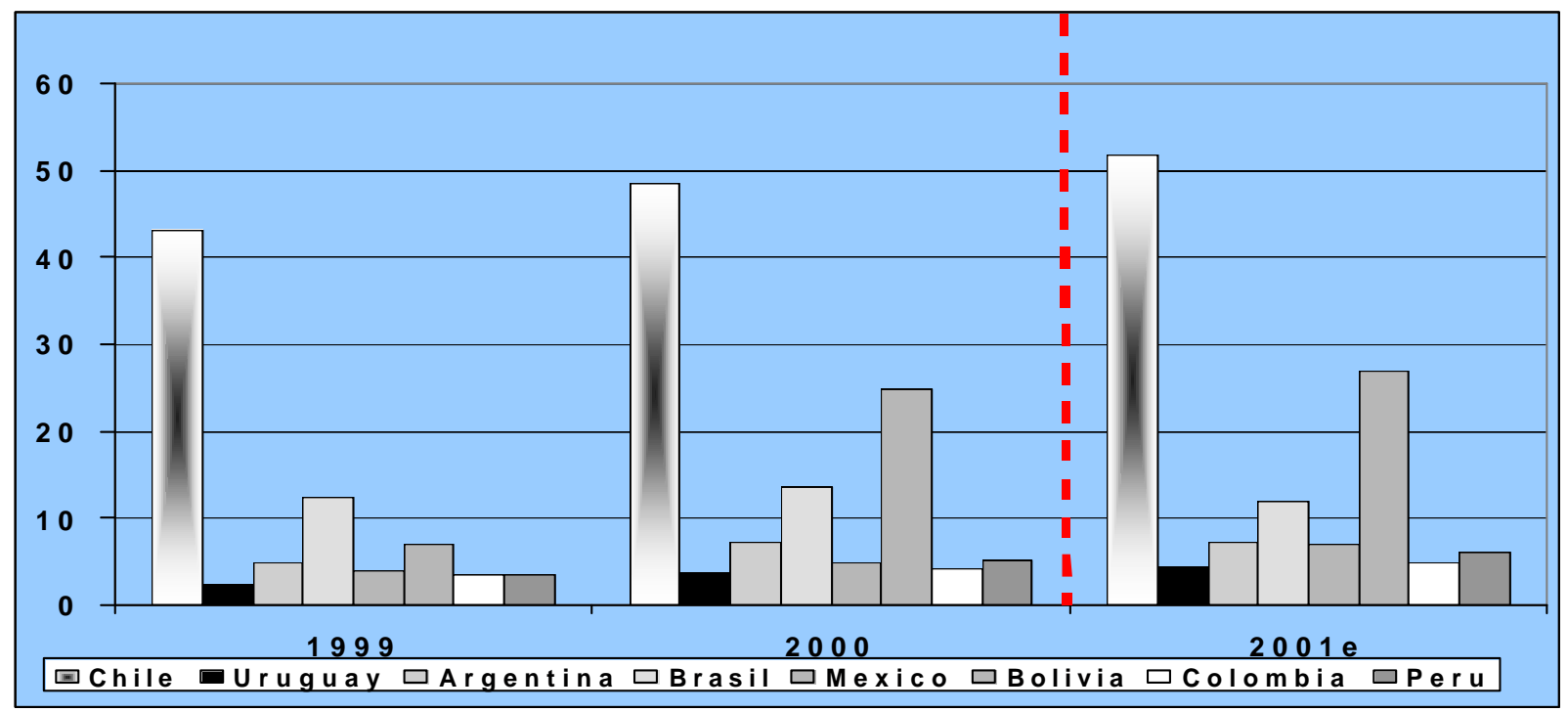

Source: Salomon Smith Barney (2001c)

Note: e stands for estimated

It should be noted that there is room for policy action to shape the development of local institutional investment. Regulation and supervision are among the most important tools, particularly as regards standards of transparency and protection of minority shareholders. More generally, there is worldwide evidence that regulatory and institutional developments must progress in parallel with liberalization and other factors in order to increase the potential growth of these markets.

\footnotetext{
${ }^{65}$ Excessive reliance on foreign saving leads to an excess of inflows in booms and to a draught in difficult situations. Hausmann and Gavin (1996) consider this to be one of the main factors for the disappointingly low growth rates of Latin American countries.
} 


\section{Conclusions}

A worldwide comparison, based on cluster analysis, indicates that per capita income is an important explanatory factor of financial development but certainly not the only one. The literature concentrates mostly on macroeconomic and institutional variables. We deal with those factors directly related with the financial system, since they are less known.

The cluster analysis also shows that Latin American countries have small financial systems compared to their per capita income and that they are relatively homogeneous in terms of financial depth. In fact, all Latin American countries, but one, can be found in the world's least financially developed group, which does not happen with other areas of the world. This regional dimension of Latin American financial systems allows to make some generalizations on a relatively sound basis, without prejudice of the differences that obviously exit among countries.

When comparing Latin America, as a region, with other emerging areas, namely Asia and Eastern Europe, several general trends are found. Latin America's financial systems are much smaller in size than those of Asia and slightly smaller than those of Eastern Europe. As regards the financial structure, Latin America is more bank-based than Asia and has a similar level of bancarization to that of Eastern Europe. Thus, Asia has the most balanced financial structure of all and, still, its banking system is twice as large as that of Latin America. Latin American bank assets are comparable to those of Eastern Europe.

Looking at efficiency and soundness, Latin America's performance is mixed. It ranks last among the regions compared in terms of efficiency, measured by the net interest margin, but soundness indicators, such as asset quality and risk-weighted capital fare relatively better. Bank credit to the private sector is much lower in Latin America than in Asia but is still high compared to Eastern Europe. One of the reasons that may explain the scarce financing to the private sector in Latin America relative to Asia is related to the very high real interest rates which Latin America has suffered from in the last two decades. Other possible explanations are the recurrent banking crises, which have led to credit crunches in some of the Latin American countries, the crowding-out by the public sector, and the weaker institutional framework, particularly as regards creditor rights.

Concerning bank ownership, in the last decade Latin America has sharply reduced the share of government-owned banks and increased foreign ownership. Eastern Europe has followed the same pattern and, today, has an even higher proportion of foreign banks and less domestic private ownership. In turn, Asia has maintained a relatively large share of government-owned banks while foreign ownership is limited. Bank concentration in Latin America is reasonably low, certainly lower than that of Eastern Europe, but has recently increased in some countries. 
Capital markets in Latin American are nearly four times smaller than those of Asia, even after the Asian crisis. The difference is larger for the stock market and smaller for the domestic bond market. Eastern Europe's capital markets are slightly larger than those of Latin America. Latin American debt markets are still geared towards the international markets even if the domestic market has developed very fast in the last few years.

As a next step, and in order to compare the financial systems of Latin American countries, a cluster exercise was conducted to classify twenty Latin American countries in terms of financial depth and income per capita. The lower correlation found in this exercise, compared to the worldwide one, implies that other factors- different than per capita income- must be more important in the case of Latin America. The analysis yielded four relatively homogeneous groups in terms of financial depth and per capita income. As a robustness exercise - to check potential large differences between financial depth and efficiency - an additional cluster exercise was conducted, including both bank size and bank efficiency, which yielded broadly similar results.

The main conclusions drawn from comparing the four clusters are the following: In some cases there are large differences in terms of financial depth; Cluster 1 (Chile and Panama) is nearly four times larger than the others. The financial system is particularly small in Cluster 4 (Colombia, Dominican Republic, Ecuador, El Salvador, Guatemala, Paraguay, Peru and Venezuela) given these countries' income per capita. Additionally, the deeper the financial system, the more balanced the financial structure; again Cluster 1 has the most balanced relation between the capital markets and the banking system while all other groups have a much larger banking system.

The banking system is nearly twice as large in Cluster 1 than in the rest. Bancarization, measured as the difference between bank deposits and cash, is also higher in Cluster 1 . Bank efficiency, measured by the net interest margin, broadly goes hand in hand with bank size. Bank credit to the private sector is low, except in Cluster 1 where it has reached levels comparable to those of emerging Asia. The scarce financing to the private sector in the remaining groups is even more pronounced if one takes into account that, in these countries, there are relatively more non-performing loans and that credit tends to be shorter-term. Among the possible reasons, the high real interest rates are key together with the large amount of bank credit to the public sector, particularly in Cluster 2 (Argentina, Brazil, Mexico, Uruguay, Trinidad and Tobago and Costa Rica). The two factors may be related, at least in some of the countries, since high interest rates may be the consequence of an inappropriate policy mix, of lax fiscal policies and restrictive monetary policies, over the last two decades. Other factors are the occurrence of banking crises and the ensuing credit crunch, particularly in Mexico. The stricter capital 
requirements and provisioning rules introduced in many of the countries may also have hampered banks' predisposition to lend although its effect should be temporary.

The structure of bank ownership has changed substantially in the last decade in most countries. Foreign ownership has increased in all groups but Cluster 3 (Honduras, Haiti, Bolivia and Nicaragua) and government-ownership is extremely small except in Cluster 2, where it is moderate. Bank concentration has generally fallen to reach reasonable low levels for international standards but the trend has changed in Cluster 1, particularly in Chile, where concentration has increased substantially from 2000 onwards.

The domestic bond markets are relatively small, since issuance was almost exclusively external in the first half of the 1990s, but they have grown very fast in the last few years. There is no clear evidence that the existence of external debt markets has hindered the development of the domestic debt market, as long as the appropriate macroeconomic conditions and the institutional setting were in place. In fact, countries with large external debt markets, particularly those belonging to Cluster 2, have managed to increase the size of their domestic bond markets at a much more rapid pace than other groups. As for the financing cost, when measured narrowly by the interest rate, the difference between the external and the domestic-currency bond markets has diminished substantially. However, the exchange rate risk also needs to be taken into account.

Although efforts have been made to reduce market risk in the domestic bond markets, in terms of the duration, the interest rate exposure and the currency of denomination, there are countries which still depend too much either on short-term debt, or on variable interest rates, or on foreign currency-denominated debt. Others have opted for indexation as a second best solution. As for the holders of bonds, there is a potential for increasing the share of institutional investors in most countries - even in those relatively developed in financial terms - as well as that of corporations and households.

Stock markets are clearly larger in the most financially developed countries (particularly those belonging to Cluster 1 and, to a lesser extent, to Cluster 2). However, in the last few years, the markets have stagnated in nearly every country, both in terms of size and efficiency, the latter measured through the turnover. This can be partly explained by the general downward trend in stock market capitalization in the world but also by the large number of Latin American enterprises which have chosen to be listed through ADRs in the New York Stock Exchange.

As for institutional investment, pension funds have grown relatively fast in the region, particularly in the most financially developed country, Chile, but the potential for growth in 
the coming years is substantial, which should contribute to the further development of the domestic bond and stock markets.

In sum, the review of several financial system-related factors, first in a regional comparison and second in a group comparison among Latin American countries, highlights their importance in explaining differences in financial development among countries. Although no conclusions on causality can be drawn from this analysis, it argues in favor of a virtuous circle in terms of financial depth and efficiency for the countries with the most appropriate structure of the financial system, particularly Cluster 1 . 


\section{APPENDIX I}

\section{A Brief Note On Cluster Analysis}

In this paper, we use a hierarchical cluster analysis based on a complete linkage method in order to identify similarities among the countries in the sample.

A hierarchical clustering analysis searches for similarities among the sample elements with the Agnes algorithm (Kauffman and Rousseeuw, 1990). This algorithm starts considering the individual as a cluster, and then aggregates single individual clusters in order to end up with a unique cluster which contains all the observations in the sample. The procedure is the following:

First, the algorithm searches for similarities between each pair of individuals through their correlations ${ }^{66}$. If the correlation between two agents $(r(i, j))$ is a similarity indicator, $1-r(i, j)$ is a dissimilarity indicator. Applying this method we obtain an Euclidean distance coefficient between two individuals:

$d(i, j) \cong \operatorname{sqrt}(2 *(1-r(i, j))$

This coefficient must be computed for each pair of individuals in the sample, which yields a matrix, D, containing all the distances among the individuals. Each element in the matrix, $d(i, j)$, represents the distance among the individual " $\mathrm{i}$ " and " $\mathrm{j}$ ".

Once the Euclidean distances among individuals are obtained, we create groups (clusters) by associating the correlations computed above as distances. We have several possibilities: maximum distance, minimum distance, average distance, etc. We take the complete linkage method (maximum distance) because of its robustness. The algorithm searches for the most similar individuals by looking for the minimum distance out of the diagonal of the matrix. An example of the above is:

\begin{tabular}{|c|c|c|c|c|}
\hline \multirow[t]{2}{*}{ Indiv. } & $\mathrm{L}$ & $\mathrm{J}$ & $P$ & indiv \\
\hline & 0 & 1.2 & 3 & $\mathrm{~L}$ \\
\hline \multirow[t]{2}{*}{$D=($} & 1.2 & 0 & 2 ) & $\mathrm{J}$ \\
\hline & 3 & 2 & 0 & $P$ \\
\hline
\end{tabular}

the minimum distance corresponds to $d(J, L)$.

\footnotetext{
${ }^{66}$ Note that this is a cross-section exercise. In the world's cluster 1996 is the year chosen and in the Latin American one 2000 , due to the availability of data.
} 
Then the algorithm takes the pair $(\mathrm{J}, \mathrm{L})$ as an individual. To obtain the new distance with respect to the rest of agents (in our example, agent $\mathrm{P}$ ), the algorithm computes:

$d(P ; J L)=\max [d(J, P) ; d(L, P)]=1 / 2{ }^{*}[d(J, P)+d(L, P)+|d(J, P)-d(L, P)|]=1 / 2 *[1.2+3+$ $|1.2-3|]=1 / 2 *(4.2+1.8)=3$

The new distance matrix would be:

$\mathrm{D}=\left(\begin{array}{llll}\mathrm{JL} & \mathrm{P} & & \\ 0 & 3 & \mathrm{JL} \\ & 3 & 0 & \mathrm{P}\end{array}\right.$

We can plot the results in a Dendogram:

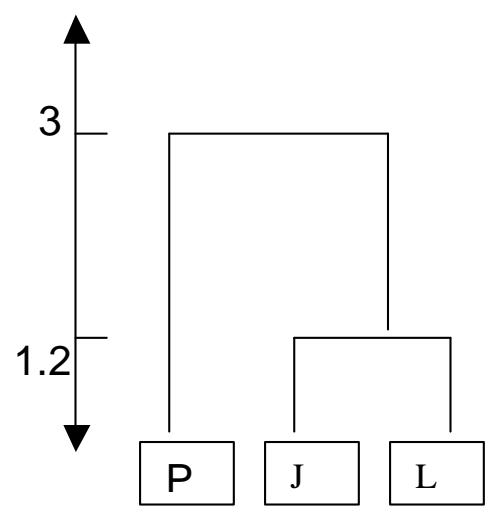

We find that $\mathrm{J}$ and $\mathrm{L}$ form a cluster at a height equal to 1.2 , and that $(\mathrm{J}, \mathrm{L})$ are associated to $P$ at a height equal to 3 . 


\section{REFERENCES}

Aguirre, Ernesto, Roberto Junguito and Geoffrey Miller (1997) "La Banca Central en América Latina. Aspectos Económicos." Banco de la República (Colombia).

Aguirre, Ernesto (2000) "Basic Reforms of the Banking Systems in Latin America." World Bank.

Alberola, Enrique, and Emiliano González Mota (2001) "Latin American Debt Markets Institutional Features and Implications for Vulnerability and Contagion." Bank of Spain, mimeo.

Allen, Franklin, and Douglas Gale (2000) "Comparing Financial Systems." MIT Press.

Arreaza, Adriana, María Amelia Fernández, and María Josefa Mirabal (2001) "Determinantes del Spread Bancario en Venezuela." Central Bank of Venezuela.

Bank for International Settlements (2001) "International Financial Statistics."

Bagehot, Walter (1873) "Lombard Street: A Description of the Money Market." Philadelphia: Orion Editions.

Bailliu, Jeannine N. (2000) "Private Capital Flows, Financial Development, and Economic Growth in Developing Countries." Bank of Canada.

Bank for International Settlements (2002) "The Development of Bond Markets in Emerging Economies." BIS Papers N. 11.

Barth, James, Gerard Caprio, and Ross Levine (2001) "Banking Systems around the Globe: Do Regulation and Ownership Affect Performance and Stability?" In Prudential Regulation and Supervision: Why It Is Important and What Are the Issues. Edited by Frederic Mishkin, National Bureau of Economic Research. University of Chicago Press.

Beck, Thorsten, Asli Demirguc-Kunt, and Ross Levine (1999) "A New Database on Financial Development and Structure". World Bank.

Beck, Thorsten, and Ross Levine (2000) "External Dependence and Industry Growth: Does Financial Structure Matter?" World Bank.

Bekaert, Geert, Campbell R. Harvey, and Robin L. Lumsdaine (2000) "Dating the Integration of World Equity Markets." National Bureau of Economic Research, NBER Working Paper N. 6724.

Berger, Allen N. (2000) "The Integration of the Financial Services Industry: Where are the Efficiencies?" Federal Reserve System, paper N. 2000-36.

Besley, Timothy (1995) "Savings, Credit and Insurance." In Handbook of Development Economics, vol. IIIA. Edited by Jehre Behrman and T.N. Srinivasan, North Holland. 
Black, Bernard S. (2000) "The Core Institutions that Support Strong Securities Markets." Business Lawyer, vol. 55, 1565-1607.

Bossone, Biagio, and Lee, Jong-Kun (2002) "In Finance, Size Matters." International Monetary Fund, Working Paper 02/113.

Boyd, John, Ross Levine, and Bruce Smith (2000) "The Impact of Inflation on Financial Sector Performance." Journal of Monetary Economics.

Buckley, Ross (1999) "Emerging Markets Debt. An Analysis of the Secondary Market." Kluwer Law International.

Bustillo, Inés, and Helvia Velloso (2000) "Bond Markets for Latin American Debt in the 1990s." CEPAL.

Caballero, Ricardo (2001) "Macroeconomic Volatility in Reformed Latin America. Diagnosis and Proposals." Inter American Development Bank.

Caballero, Ricardo (2002) "Coping with Chile's External Vulnerability: a Financial Problem." Banco Central de Chile, Working Paper N. 154.

Caprio, Gerard, and Daniela Klingebiel (1997) "Bank Insolvency: Bad Luck, Bad Policy or Bad Banking." World Bank.

Caprio, Gerard, and Daniela Klingebiel (1999) "Episodes of Systemic and Borderline Financial Crises." World Bank.

Caprio, Gerard, James A. Hanson, and Patrick Honohan (2001) "The Case for Liberalization and Some Drawbacks." In Financial Liberalization: How Far, How Fast? Edited by Caprio, Honohan, and Stiglitz. Cambridge University Press.

Catalán, Mario, Gregorio Impávido, and Alberto R. Musalem (2000) "Contractual Savings and Stock Market Development: Which Leads?" World Bank, Policy Research Working Paper N. 2421.

Chen, Bee-Lon, Yeong-Yuh Chiang, and Ping Wang (1996) "A Schumpeterian Model of Financial Innovation and Endogenous Growth." Mimeo.

Claessens, Stijn, Asli Demirguc-Kunt, and Harry Huizinga (2000) "How Does Foreign Entry Affect the Domestic Banking Market?" In The Internationalization of Financial Services: Issues and Lessons for developing Countries. Edited by Claessens and Jansen. Kluwer Law International.

Cole, David C., and Betty F. Slade (1999) "Premature Liberalization of Government Debt Markets." World Bank.

Comisión Nacional Bancaria y de Valores (2002) "Información Estadística." 
Crystal, Jennifer S., B. Gerard Dages, and Linda S. Goldberg (2001) "Does Foreign Ownership Contribute to Sounder Banks in Emerging Markets? The Latin American Experience." Federal Reserve Bank of New York.

Cuadro, Lucía, Gallego Herrero, Sonsoles, and García Herrero, Alicia (2002) "Why do countries develop more financially than others?" Mimeo

Cukierman, Alex, Steven B. Webb, and Bilin Neyapti (1992) "Measuring the Independence of Central Banks and its Effect of Policy Outcomes." The World Bank Economic Review, vol. 6, N.3, 353-398.

Cull, Robert, Lemma W. Senbet, and Marco Sorge (2000) "Deposit Insurance and Financial Development." World Bank.

Davis, E. Philip (2001) "Multiple Avenues of Intermediation, Corporate Finance and Financial Stability." International Monetary Fund, Working Paper N. 115.

Demetriades, Panicos, and Bassam Fattouh (2000) "Unproductive Credit and the SouthKorean Crisis." Mimeo.

Demirguc-Kunt, Asli, and Ross Levine (1996) "Stock Markets, Corporate Finance, and Economic Growth: An Overview." The World Bank Economic Review, vol. 10(2), 223-240.

Demirguc-Kunt, Asli, and Enrica Detragiache (1998) "Financial Liberalization and Financial Fragility." World Bank, Working Paper N. 1917.

Demirguc-Kunt, Asli, and Ross Levine (1999) "Bank-Based and Market-Based financial Systems: Cross-Country Comparisons." World Bank, Policy Research Working Paper N. 2143.

Demirgurc-Kunt, Asli, and Tolga Sobaci (2000) "Deposit Insurance Around the World: A Data Base." World Bank.

Demirguc-Kunt, Asli, and Vojislav Maksimovic (2001) "Firms as Financial Intermediaries: Evidence from Trade Credit Data." World Bank, Working Paper N. 2696.

Diaz-Alejandro, Carlos (1985) "Good-Bye Financial Represion, Hello Financial Crash." Journal of Development Economics, N. 19 (September/October), 1-24.

Fama Eugene F., and William F. Sharpe (1970) "Efficiency Capital Markets: A Review of Theory and Empirical Work." In The Journal of Finance, vol. 25, N. 2, 383-417.

Federación Iberoamericana de Bolsas de Valores (2000 and 2001) "Síntesis Estadística."

Fernández-Arias, Eduardo, and Ricardo Hausmann (2000) "Getting it Right: What to Reform in International Financial Markets." Inter-American Development Bank.

Fry, Maxwell et al., Editors (1999) "Payment Systems in Global Perspective." Routledge. 
Fuchs-Schundeln, Nicola, and Norbert Funke (2001) "Stock Market Liberalizations: Financial and Macroeconomic Implications." IMF, Working Paper N. 01/193.

Galindo, Arturo, Alejandro Micco and Guillermo Ordoñez (2002) "Financial Liberalization and Growth: Empirical Evidence." Inter.-American Development Bank.

Galindo, Arturo, Fabio Schiantarelli, and Andrew Weiss (2002) "Does Financial Liberalization Improve the Allocation of Investment?: Micro Evidence From Developing Countries." Inter-American Development Bank.

García Herrero, Alicia (1997) "Banking Crises in Latin America in the 1990s: Lessons from Argentina, Paraguay, and Venezuela." IMF, Working Paper N. 140.

García Herrero, Alicia (1999) "El Sistema Bancario Latinoamericano: Desarrollo a pesar de las Crisis." Cuadernos de Información Económica, N. 148/149.

Goldman Sachs (2002) "Latin American Financial Services Monthly." Various numbers.

Gray, Simon, and David Woo (2000) "Reconsidering External Financing of Domestic Budget Deficits: Debunking Some Received-Wisdom." IMF, Policy Discussion Paper N. 00/8.

Greenwood, Jeremy, and Boyan Jovanovic (1990) "Financial Development, Growth, and the Distribution of Income." Journal of Political Economy, vol. 98, 1076-1107.

Harwood, Alison (2000) "Building Local Bond Markets: Some issues and Actions." In Building Local Bond Markets. An Asian Perspective, International Financial Corporation.

Hausmann, Ricardo, and Michael Gavin (1996) "Hacia la Estabilidad y el Crecimiento en una Región Vulnerable a las Turbulencias: el Reto Político para América Latina." In Hacia la Estabilidad y el Crecimiento en América Latina: Cuestiones Políticas y Perspectivas de las Economías Vulnerables, Organization for Economic Cooperation and Development and Inter-American Development Bank.

Hawkins, John, and Dubravko Mihaljek (2001) "The Banking Industry in the Emerging Market Economies: Competition, Consolidation and Systemic Stability - An Overview." Bank of International Settlements, BIS Papers N. 4.

Heaney, Richard, Vince Hooper, and Martín Jaugietis (2002) "Regional Integration of Stock Markets in Latin America." Journal of Economic Integration.

Honohan, Patrick, and Daniela Klingebiel (2000) "Controlling the Fiscal Costs of Banking Crises." World Bank, Policy Research Working Paper N. 2441.

Inter-American Development Bank (2001) "El motor del crecimiento: Progreso económico y social en América Latina. Informe 2001." Inter-American Development Bank.

International Monetary Fund (2001) "International Financial Statistics." 
Jaffee, Dwight, and Mark Levonian (2000) "The Structure of Banking Systems In Developed and Transition Economies." Federal Reserve Bank of San Francisco.

Kaminsky, Graciela, and Carmen Reinhart (1999) "The Twin Crisis: Causes of Banking and Balance of Payments Problems." American Economic Review.

Kaminsky, Graciela, Richard Lyons, and Sergio Schmuckler (2000) "Mutual Fund Investment in Emerging Markets: An Overview." World Bank.

Kaufman, Leonard, and Peter J. Rousseeuw (1990) "Finding Groups in Data: an Introduction to Cluster Analysis." John Wiley and Sons.

Khan, Mohsin S., Abdelhak S. Senhadji, and Bruce D. Smith (2001) "Inflation and Financial Depth." International Monetary Fund, Working Paper N. 44.

King, Robert G., and Ross Levine (1993a) "Finance and Growth: Schumpeter Might Be Right." Quarterly Journal of Economics, vol. 108(3), 717-37.

King, Robert G., and Ross Levine (1993b) "Finance, Entrepreneurship, and Growth." Journal of Monetary Economics, vol. 32(3), 513-42.

Kono, Masamichi, and Ludger Schucknecht (1999) "Financial Services Trade, Capital Flows, and Financial Stability." World Trade Organization.

Kroszner, Randall S. (1998) "On the Political Economy of Banking and Financial Regulatory Reform in Emerging Markets." Graduate School of Business, University of Chicago.

La Porta, Rafael, Florencio Lopez-de-Silanes, Andrei Shleifer, and Robert W. Vishny (1997) "Legal Determinants of External Finance." Journal of Finance, vol. 52, 1131-1150.

La Porta, Rafael, Florencio López-de-Silanes, and Guillermo Zamarripa (2000) "Soft Lending and Hard Landing: Related Lending in Mexico." Harvard University.

La Porta, Rafael, Florencio Lopez-de-Silanes, and Andrei Shleifer (2002) "Government Ownership of Banks." Journal of Finance, (forthcoming).

Levine, Ross (1991) "Stock Markets, Growth, and Tax Policy." In Journal of Finance, vol. $46,1445-65$.

Levine, Ross, and Sara Zervos (1998) "Stock Markets, Banks, and Economic Growth." American Economic Review, vol. 88, 537-558.

Levine, Ross, Norman Loayza, and Thorsten Beck (1999) "Financial Intermediation and Growth: Causality and Causes." Central Bank of Chile, paper N. 56.

Lombardo, Davide, and Marco Pagano (1999) "Legal Determinants of the Return on Equity." CEPR, Discussion Papers N. 2275. 
Mathieson, Donald J., and Garry J. Schinasi (2001) "International Capital Markets: Developments, Prospects and Key Policy Issues." International Monetary Fund.

McKinnon, Ronald I. (1973) "Money and Capital in Economic Development." Brookings Institution.

McKinnon, Ronald I., and Huw Pill (1997) "Credible Economic Liberalization and Overborrowing." American Economic Review, vol. 87, 189-193.

Moel, Alberto (2000) "The Role of American Depositary Receipts in the Development of Emerging Markets." Harvard Business School.

Moodys Investor Service (2000 and 2001) "Banking Statistical Supplement." Moodys, various issues.

Rajan, Raghuram G., and Luigi Zingales (1998) "Financial Dependence and Growth." American Economic Review, vol. 88(3), 559-586.

Rojas-Suárez, Liliana and Steven Weisbrod (1997) "Triannual Markets and the Behaviour of Private Savings in Latin America." Inter-American Development Bank.

Rousseau, Peter L., and Richard Sylla (2001) "Financial Systems, Economic Growth, and Globalization." National Bureau of Economic Research, NBER Working Paper N. 8323.

Rybczynski, T.M. (1997) "A New Look at the Evolution of the Financial System." In The Recent Evolution of Financial Systems. Edited by Jack Revell. Macmillan.

Salomon Smith Barney (2000 and 2001b) "Bank Reference Guides." Various numbers.

Salomon Smith Barney (2001a) "Foreign Financial Institutions in Latin America."

Salomon Smith Barney (2001c) "Private Pension Funds in Latin America."

Salomon Smith Barney (2002a) "Latin American Bank Annual. 2002 Edition."

Salomon Smith Barney (2002b) "Country Financial Systems." Various numbers.

Schumpeter, Joseph A. (1911) "A Theory of Economic Development." Harvard University Press.

Segalla Afanasieff, Tarsila, and Priscilla Maria Villa Lhacer (2000) "The Determinants of Bank Interest Spread in Brazil." Central Bank of Brazil.

Stallings, Barbara, and Rogerio Studart (2001) "Financial Regulation and Supervision in Emerging Markets: The Experience of Latin America since the Tequila Crisis." CEPAL.

Tuya and Zamalloa (1994) "Issues on Placing Banking Supervision in the Central Bank." In Framework for Monetary Stability. Edited by T. Balino and C. Cottarelli. International Monetary Fund. 
Vittas, Dimitri (1998) "Institutional Investors and Securities Markets: Which Comes First?" World Bank, Development Research Group. Working Paper N. 2032.

Vittas, Dimitri (2000) "Pension Reform and Capital Market Development: "Feasibility" and "Impact" Preconditions." World Bank, Policy Research Working Paper N. 2414.

Williamson, John, and Molly Mahar (1998) "A Survey of Financial Liberalization." Princeton University, International Finance Section, Essays in International Finance N. 211.

World Bank (2001a) "Developing Government Bond Markets in Latin America: A Regional Snapshot." Mimeo.

World Bank (2001b) "Finance for Growth: Policy Choices in a Volatile World." Oxford University Press.

World Bank (2001c) "World Development Indicators." 